University of Louisville

ThinkIR: The University of Louisville's Institutional Repository

Electronic Theses and Dissertations

$5-2015$

\title{
Provisions of labor : prehistoric evidence for economic behavior at Ghost Ranch, New Mexico.
}

David Alan Hoefer 1959-

University of Louisville

Follow this and additional works at: https://ir.library.louisville.edu/etd

Part of the Anthropology Commons

\section{Recommended Citation}

Hoefer, David Alan 1959-, "Provisions of labor : prehistoric evidence for economic behavior at Ghost Ranch, New Mexico." (2015). Electronic Theses and Dissertations. Paper 2143.

https://doi.org/10.18297/etd/2143

This Master's Thesis is brought to you for free and open access by ThinkIR: The University of Louisville's Institutional Repository. It has been accepted for inclusion in Electronic Theses and Dissertations by an authorized administrator of ThinkIR: The University of Louisville's Institutional Repository. This title appears here courtesy of the author, who has retained all other copyrights. For more information, please contact thinkir@louisville.edu. 


\title{
PROVISIONS OF LABOR: PREHISTORIC EVIDENCE FOR ECONOMIC BEHAVIOR AT GHOST RANCH, NEW MEXICO
}

By

David Alan Hoefer

\author{
A Thesis \\ Submitted to the Faculty of the College of Arts and Sciences \\ of the University of Louisville in Partial Fulfillment \\ of the Requirements for the Degree of
}

Master of Arts in Anthropology

Department of Anthropology

University of Louisville

Louisville, Kentucky

May 2015 
Copyright 2015 by David Alan Hoefer

All rights reserved 

PROVISIONS OF LABOR: PREHISTORIC EVIDENCE

FOR ECONOMIC BEHAVIOR AT GHOST RANCH, NEW MEXICO

By

David Alan Hoefer

A Thesis Approved on

April 9, 2015

by the following Thesis Committee

Thesis Director - Jonathan Haws, Ph.D.

Phil DiBlasi

Carol Hanchette, Ph.D. 


\section{DEDICATION}

This thesis is dedicated to my family

Robin Morgan Hoefer

and

Wyatt Alan Hoefer

for patience, support, and understanding

In memoriam

Richard Lee Binggeli (1937-2014)

Crew Chief, GR-2 


\section{ACKNOWLEDGEMENTS}

I would like to thank my advisor, Dr. Jonathan Haws, for his long-standing guidance and support of my desire to become an archaeologist. I would also like to thank Phil DiBlasi and Dr. Carol Hanchette for their willingness to serve on my committee. Drs. Jennie Burnet, Fabian Crespo, Lisa Markowitz, and Shawn Parkhurst have each contributed significantly to my knowledge of anthropology. Dr. Christopher Tillquist offered valuable assistance in navigating the sometimes-labyrinthine requirements of graduate school. Finally, my heartfelt gratitude goes out to the four pillars of the Ghost Ranch Archaeological Seminar: Cheryl Muceus, John Hayden, Maisie Morris, and the late Richard Binggeli. 


\section{ABSTRACT \\ PROVISIONS OF LABOR: PREHISTORIC EVIDENCE \\ FOR ECONOMIC BEHAVIOR AT GHOST RANCH, NEW MEXICO}

David Alan Hoefer

April 9, 2015

Excavations at Ghost Ranch of two hunter-gatherer rock shelters, GR-2 and GR-145, offer new opportunities for assessing prehistoric land-use in the Piedra Lumbre Basin of northcentral New Mexico. Intersite analysis of these remains provides new data for understanding subsistence organization during the Southwestern Archaic and Formative periods. Faunal and floral assemblages from the two sites, located five km apart and overlapping chronologically, suggest divergent patterns of resource collection, processing, and use by groups taking up temporary residence in a seasonal round. I argue that economic agency provides the best explanation for the sites' differentiated remains. Furthermore, I propose that, based on this and related evidence, the divisions of labor characteristic of agricultural societies might have their origin in specialized behaviors practiced in discrete locations by prehistoric foraging peoples. 


\section{TABLE OF CONTENTS}

Page

Acknowledgements

iv

Abstract $\quad$ V

List of Tables $\quad$ vii

List of Figures $\quad$ viii

$\begin{array}{ll}\text { Introduction } & 1\end{array}$

$\begin{array}{ll}\text { Research Context } & 5\end{array}$

$\begin{array}{ll}\text { Methods, Materials, and Analysis } & 27\end{array}$

$\begin{array}{ll}\text { Discussion } & 70\end{array}$

Summary and Conclusion $\quad 99$

$\begin{array}{ll}\text { References } & 105\end{array}$

$\begin{array}{ll}\text { Curriculum Vitae } & 128\end{array}$ 


\section{LIST OF TABLES}

Table

Page

1. Place-names 4

2. Birds of Ghost Ranch and North-central New Mexico 12

3. Chronology 22

4. Botanical Ecology at GR-145 33

5. $\mathrm{pH}$ Test Results: GR-2 and GR-145 37

6. GR-2 Phosphate Tests 39

7. Comparative Bone Counts at GR-2 and GR-145 48

8. Recent GR-145 Radiocarbon Dates 49

9. Distribution of Bones within the Matrix (GR-145, Box 4 Only) 55

10. Distribution of Bones within the Matrix (GR-145, All Boxes) 56

11. Human-modified Bone (GR-145) 57

12. Animal Bone by Linnean Taxa (GR-145) 59

13. Artiodactyl Elements by Count (GR-145) 61

14. Mule Deer Elements by Count (GR-145) 61

15. Long-bone Elements as Fragmentation Measure (GR-145) 63

16. Distribution of Bones within the Matrix (GR-2) 65

17. Bone Classified by Mammal Size in Chronological Overlap (GR-2) 65

18. Plant Taxa Recovered from Macrobotanical Samples at GR-2 68

19. Pollen Counts and Percentages for 4 Hearthstone Samples (GR-2) 77

20. Bone-count Comparisons by Time Period (GR-2 \& GR-145) 80

21. Faunal Sort by Mammal Size (GR-2) 80

22. Distribution of Remains Above and Below the Overlap Horizon (GR-2) 81

23. Selected Early Dates for the Appearance of Maize in the Southwest U.S. 89 


\section{LIST OF FIGURES}

Figure Page

1. Map location of Ghost Ranch 6

2. Pueblos of the Northern Rio Grande 18

3. Map location of GR-2 28

4. GR-2 view from south 29

5. GR-2 in plan 30

6. GR-2 in profile 31

7. Map location of GR-145 32

8. GR-145 view from northeast 34

9. GR-145 view from southwest 34

10. Sample soil profile at GR-2 35

11. Sample soil profile at GR-145 36

12. Excavated bone from one unit-level at GR-145 40

13. Wide range of radiocarbon dates at GR-2 50

14. Comparative radiocarbon dates (GR-145 and GR-2) 51

15. Scatterplot distribution of radiocarbon dates at GR-2 52

16. Long-bone fragments from GR-145 57

17. Major hunt taxa at GR-145 60

18. Butchery anvil at GR-145 64

19. Double-burner hearth feature at GR-2 71

20. Human-modified bone at GR-145 74

21. Panel-1 petroglyphs near GR-2 78

22. Point technology at GR-2 and GR-145 84

23. Rock-mulch remains at Sapawe 93

24. Olivella shell bead from GR-145 97

25. Archaic flagstone floor at GR-2 104 


\section{INTRODUCTION}

New Mexico sits at the heart of one of the most productive regions of North American archaeology. Tucked away among the state's beautiful but rugged features is a diverse array of remains, ranging from simple lithic scatters to the magnificent architectural ruins of Chaco Canyon. The Land of Enchantment has benefited in this regard from the preservational quality of its environment and the liveliness of its human prehistory. Archaeologists have responded accordingly: their activity precedes by decades New Mexico's statehood (Ramenofsky \& Feathers 2002) and boasts critical contributions from pathfinders in the discipline, including Adolph Bandelier, Edgar Lee Hewett, Alfred Kidder, Nels Nelson, Florence Hawley, Emil Haury, and many others (Cordell 1997).

That said, not every archaeological region in New Mexico is equally well known.

Certain areas - the San Juan Basin of the Eastern Anasazi, the Middle Rio Grande Valley of the late prehistoric pueblos - dominate others, especially those without romantic, eyecatching ruins. The Piedra Lumbre Basin, adjoining the Middle Rio Chama Valley and home to Ghost Ranch, is one of those overlooked locations. Though noted for its contributions to Triassic paleontology (Lucas, et al, 2003), Ghost Ranch has contributed little to the archaeological record, despite abundant evidence for prehistoric use and habitation.

This oversight intrigues all the more when one considers the nature of the cultural remains in the area. The Piedra Lumbre Basin, and the broader Northern Rio Grande region in which it sits, give every indication of having been a borderland or buffer zone between a 
medley of cultures, especially late in prehistory, when the massive Anasazi footprint to the west left only a negligible impression in the area (Maxwell 2000, Whitten \& Powers 1980). The region witnessed a long arc of ephemeral presences, transitional cultures, experimental lifeways, and ethnogenesis events - a geographic margin where self-aware peoples came to be or to die, a zone of metamorphosis and change, a "between place" or "hinterland" like others in the ancient Southwest (Douglas 1995, Sullivan \& Bayman, eds., 2007). I propose to address archaeology's unfortunate neglect of the Piedra Lumbre region by:

- Using data from two archaeological sites at Ghost Ranch as the basis for original research and my master's thesis in anthropology at the University of Louisville.

- Addressing a critical research question that benefits from insights gained in seven years of field experience at Ghost Ranch, combined with knowledge derived from eight years of taking and teaching classes at the university.

- Drawing out the possible implications of this research, in the context of Northern Rio Grande prehistory, as it regards the role of economic agency in cultural evolution.

\section{$\underline{\text { Research question }}$}

"In fact, the Archaic can be compared to a first-year expansion franchise in professional sports - like player quality, data quality is often suspect; like fans, committed researchers are often few; and both face an uphill struggle to compile a good record."

- Bruce Huckell (in P. Fish \& Reid, eds., 1996:7)

One reason for the relative disinterest in Piedra Lumbre archaeology is the lack of landscape ruins. The cultural sites identified in surveys at Ghost Ranch have artifacts and features that we associate with the hunt-and-gather lifeways of the Archaic - a subtle array of lithic fragments, bone scraps, charcoal lenses, and fire-cracked rock. The two sites under 
excavation by the Ghost Ranch Archaeological Seminar, GR-2 and GR-145, have produced radiocarbon dates spanning from the earliest Archaic to the Formative and Historic periods. Most remains fall within the Archaic but even those traceable to more recent times (e.g., potsherds and arrowheads) are otherwise found in context with the remnants of a foraging subsistence, which persisted in the Middle Rio Chama Valley until the tardy appearance of agriculture during the Coalition Period (A.D. 1200-1325) (Post in Vierra, ed., 2013, Wendorf \& Reed 1955).

I have therefore chosen to focus my research on the contrasting cultural remains at GR-2 and GR-145, as indicative of differential food-collection strategies during the long transition from foraging to large-plot agriculture. The question that I am addressing is, given the commonalities of two close-together sites with overlapping usage in time, why did GR-2 and GR-145 produce distinctive archaeological profiles?

Thesis

I will answer this question by assessing the comparability of GR-2 and GR-145, based on geography, geology, soil chemistry, ecology, and chronology; executing intersite and intrasite analyses of faunal and other subsistence data, after evaluating appropriate statistical methods; and generating a thesis for the apparent difference in volume and nature of cultural assemblages at the two sites. My conclusion is that the critical explanatory factor is human agency, and that we can see at Ghost Ranch evidence for economic specialization that, at a later date, becomes one of the bases for agricultural society. Put another way, a hunter-gatherer strategy of "localization as specialization" represents a cultural preadaptation, by means of a division of labor, to the village-based, food-production economies of late prehistory. 
The Northern Rio Grande offers, in many ways, a special case of Southwestern archaeology. I provide a natural, cultural, and historic context for my thesis in the next section.

Note on place-names

Archaeology is a scale-sensitive discipline (Dincauze 2000, Stein in Stein \& Linse, eds., 1993), with implications extending to place-names. In the course of this paper, I will refer to a number of geographic locations, which can be related in the following manner:

Table 1: Place-names

\section{Place Description}

GR-2 \& GR-145 A pair of archaeological sites located on Ghost Ranch property

Ghost Ranch A privately held corporate entity located north of the Rio Chama and Abiquiu Reservoir, encompassing a wide range of potential archaeological sites

Piedra Lumbre Basin A physiographic region formed by the Rio Chama and its tributaries, in which Ghost Ranch is located. A/K/A: Chama Basin (Lucas, et al, 2003)

Middle Rio Chama Valley

Northern Rio Grande archaeological district
The middle segment of the Rio Chama, adjoining and roughly equivalent to the Piedra Lumbre Basin

The broader region in which the Rio Chama Valley sits, often defined as the segment of the Rio Grande drainage north of Santa Fe, New Mexico 


\section{RESEARCH CONTEXT}

"Imagine... where northern Rio Grande Archaic studies might be today if [archaeology's] talented pioneers had focused their keen interest on the charcoalstained soil lenses, chipped stone concentrations, and fire-cracked rock middens that dotted the landscape surrounding the pueblo ruins they knew so well."

- Stephen S. Post (in Schlanger, ed., 2002:33)

In prehistory, foraging peoples traveled or utilized nearly all the landscape, yet archaeologists invest a disproportionate amount of time on flagship locations, due to the dense remains or monumental nature of these sites. The North American Southwest offers a striking example of this pattern, with the late prehistoric aggregations of the Hohokam and the Ancestral Puebloans drawing major attention and the "between places" in which these and other peoples collected resources being relatively ignored (Douglas 1995). The Piedra Lumbre Basin is a prime example of a "between place." While archaeologically visible, it falls in a transitional landscape between different physiographic, ecologic, and culturehistoric regions and has heretofore avoided the kind of intensified study that we associate with Chacoan great houses, Classic-Period pueblos and cliff dwellings, or Mimbrean pottery. Geography

I want to start by providing a context for my research - "the fossilized structure of the total cultural system" (Binford 1964:425). Ghost Ranch sits in the Piedra Lumbre Basin of Rio Arriba County, in the north-central part of New Mexico (latitude 36 $19^{\prime} 47^{\prime}$, longitude 106²8'29”) (climate-charts.com <http://www.climate-charts.com $>$ ). The one-time dude ranch, now conference center, lies north of the Rio Chama, a major tributary of the Rio 
Grande, near the Abiquiu Reservoir, approximately 12 miles northwest of Abiquiu. Noted for its association with the painter, Georgia O'Keeffe, Abiquiu is the closest habitation of any size in a compelling, if largely empty, panorama of jumbled geologic formations and vaulting western skies (Figure 1).

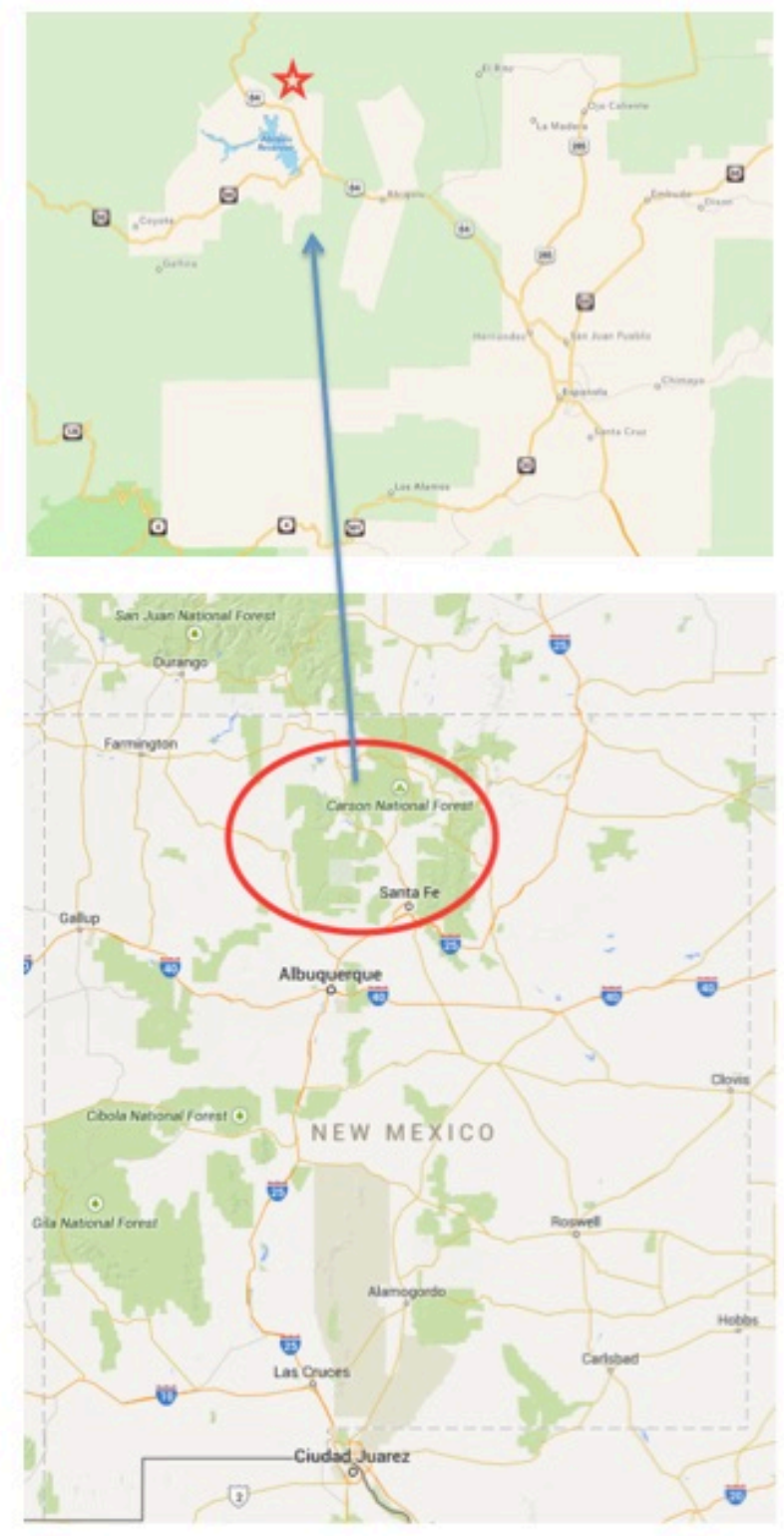

Figure 1. Ghost Ranch is located in the high desert country of north-central New Mexico, approximately one-and-a-quarter hours northwest of Santa Fe by car. The star indicates the site of the ranch. Source: Apple Maps (Feb. 10, 2015). 


\section{Geology}

An arid high desert hammocked between the southern Jemez Mountains and the San Juan Mountains to the north, the Piedra Lumbre Basin forms "the easternmost geologic expression of the colorful formations and land forms that characterize the Colorado Plateau..." (Schaafsma 2002:4). The study area and its surrounds, though lacking in spectacular ruins, are rich in remains: one survey documented 288 Archaic sites and 646 undiagnostic scatters in Rio Arriba County, the third-highest total in New Mexico (Vierra in Vierra, ed., 1994:19).

Despite its similarities with the geology of the Colorado Plateau, the Abiquiu region lies slightly east of the Plateau within the Southern Rocky Mountain physiographic province, a high-contrast zone "of badlands and dissected pediments" (Smith 1938:933), which intrudes along a narrow north-south axis west of the Rio Grande Rift. The Rio Chama, flowing southeast from its origins in the San Juan Mountains to its confluence near the town of Española, occupies one of several major breaks in the regional topography. The province has noticeable disparities in elevation, ranging from $1,524 \mathrm{~m}(\approx 5,000$ feet $)$ above sea level in the river valleys to $4,267 \mathrm{~m}(\approx 14,000$ feet) in the mountains (Cordell 1997). "A short 24 to 50 km trip could take an Archaic hunter from the lowest riparian zones into the heart of deer and elk country,” writes Stephen Post (in Schlanger, ed., 2002:34).

Ghost Ranch in particular is well known for its fossiliferous sedimentary rock dating back 100 to 300 mya. There are numerous river-deposited formations but some are attributable to the dunal systems, saline lakes, and shallow inland seas that occupied the area during the long prehistoric meander of the Mesozoic. The primary stratigraphic components, on display in the ranch's sheer-faced outcrops, include, from youngest to oldest, Jurassic- 
period Morrison Formation, Bluff Sandstone, Summerville Formation, Todilto Formation, and Entrada Sandstone units, deposited on a Triassic base of Chinle Group conglomerates (Lucas, et al, 2003, Price 2010).

More recently, the region was impacted by a mountain-building episode, the Laramide orogeny, which occurred between 30 and 70 mya. The Piedra Lumbre Basin formed gradually during this time, resulting from the long-term effects of erosion combined with faulting and folding events, moderated to a great extent by the stability of the Colorado Plateau (Baars 2000, Blakey \& Ranney 2008, Koning, et al, 2006). "Consequently, the rocks around Ghost Ranch are relatively flat-lying and are only mildly deformed by broad-scale folding and localized faulting with offsets of less than 120 feet," writes L. Greer Price (2010:113). One draw to the region for prehistoric peoples was the chert and obsidian they mined from the nearby volcanic peaks, Polvadera and Pedernal, for projectile points and other tools (GRAB 2009, Warren 1974). Lithic cultural debris is bountiful at Ghost Ranch. Climate

Long-term weather shows similarities with that of the broader Colorado Plateau, precipitation being limited to a bimodal pattern of midsummer monsoons and wintertime rains or snow (Cordell 1997, Vivian 1990). Total annual precipitation is minimal; during a 24-year period beginning in 1957, the Abiquiu area received, on average, only $35.5 \mathrm{~cm}(\approx 14$ inches) of rain and snow per year (Morris \& Haggard 1985). Rainfall reaching the ground rarely stays put. Pan evaporation rates in neighboring Fruitland are as much as eight times the mean annual precipitation for the same area (Allan in Reher, ed., 1977).

Temperature variations can be extreme, based on elevation, air currents, insolation, and other factors. For example, mean annual temperatures of $10^{\circ} \mathrm{C}\left(\approx 50^{\circ} \mathrm{F}\right)$ have been 
recorded at Abiquiu Dam (Gabin \& Lesperance 1977). But the National Park Service recorded mean annual temperatures in the $21.1-25.0^{\circ} \mathrm{C}\left(\approx 70-77^{\circ} \mathrm{F}\right)$ range at nearby Bandelier during the 30-year period of 1961-1990 (Davey, et al, 2006). Abiquiu averages about 140 frost-free days per year, insufficient for dry farming most agricultural staples (Moore 1992).

According to Vivian, "No major changes in climate have occurred in the past 10,000 years in the northern Southwest" (1990:19), but paleoclimatic data suggest lesser cycles of various duration for both temperature and precipitation. Though researchers agree that Ernst Antevs's Altithermal model is too simple to offer an entirely accurate picture of prehistoric climate, it does appear to be valid in a rough, rule-of-thumb sort of way for the Colorado Plateau and adjacent regions (Antevs 1955, Euler, et al, 1979, Irwin-Williams \& Haynes 1970, Johnson \& Holliday 1986, van Devender \& Spaulding 1979). As Brian Fagan notes, in the American Southwest, “[The Middle Holocene] was a period of constant change with generally drier conditions," consistent with the claims of the Antevs model (2005:304). Local research draws similar conclusions (Periman 2005).

Recent additions to the tree-ring record buttress the claim of regionally shared weather patterns over a 1,400-year span extending from the Late Archaic to the present day. Paleoclimatic analysis underscores the long-term resilience of the bimodal-precipitation regime, interrupted only once, by the severe drought conditions of A.D. 1250-1450 that helped bring Chaco to ruin. Comparative data from Chama, Jemez, and Arroyo Hondo near Santa Fe show regional synchronization of wet-dry fluctuations throughout the period covered by the tree rings (Rose, et al, 1981, Towner \& Salzer in Vierra, ed., 2013). 


\section{Ecology}

Just as the Piedra Lumbre Basin forms a geologic corridor between the Rio Grande Rift and the Colorado Plateau, it also acts as a transitional zone between two major biotic provinces: the Great Basin Conifer Woodland and the Plains and Great Basin Grasslands (Brown 1994, McBride 2008). Assigned originally to the Navahonian province by Dice (1943), the local ecology is defined by abundant piñon-juniper stands paired with an intermittent ground cover of xeric shrubs and grasses (Bailey 1980). Co-dominant deciduous trees, such as the Gambel Oak (Quercus gambelii), are also present in some locations (DickPeddie 1993). The piñon-juniper adaptation evolved out of the Great Basin to the north, as a response to the high-frequency temperature minima of winter and the thin, rocky soils covering the region (Brown 1994). ${ }^{1}$

The primary soil association in Rio Arriba County is Rock Land-TorriothentsHaplargids. Common to broken landscapes of weathered sedimentary rock, "[t]he soils of this association are used principally for grazing livestock and wildlife," according to Maker, et al (1978:79). As early as 1844, the American traveler and trader, Josiah Gregg, opined that the New Mexican uplands "must chiefly remain unproductive; owing, in part, to the sterility of the soil," absent irrigation or floodwater agriculture (in Moorhead, ed., 1974 [1844]:104).

A varied flora accompanies the interwoven stands of Piñon pine (Pinus edulus) and Juniper (Juniperus spp.) marking the region. Understory plants include Sagebrush (Artemisia tridentata), Rabbitbrush (Ericameria nauseosa), Winterfat (Krascheninnikovia lanata), Shadscale (Atriplex confertifolia), Banana yucca (Yucca baccata), and Cliffrose (Cowania Mexicana). Cholla (Cylindropuntia spp.) and Broom Snakeweed (Gutierrezia sarothrae) are

\footnotetext{
${ }^{1}$ The Ghost Ranch sites can also be classified as residing in C. Hart Merriam's Upper Sonoran life zone - "a verdant, high-desert bosque" (Poling-Kempes 1997:6).
} 
among the primary shrubby species. Grasses include the Grama grasses (Bouteloua spp.), Galleta grass (Hilaria jamesii), Indian ricegrass (Achnatherum hymenoides), Muhly grasses (Muhlenbergia spp.), and Dropseeds (Sporobolus spp.) (GRAB 2009, McBride 2008). Botanists have cataloged about 270 plant species in the Northern Rio Grande, roughly 50 percent of which are useful to humans and other animals (Post in Schlanger, ed., 2002).

The diversity of animal communities reflects the mixed wood- and grasslands in which they live. "The non-domestic mammalian fauna of the Colorado Plateau includes 126 natives and the introduced house mouse (Mus domesticus), and humans," write Zimmerman and Carr (in van Riper III \& Cole, eds., 2004:76). Traditional game animals consist of mule deer (Odocoileus hemionus), elk or wapiti (Cervus canadensis), bighorn sheep (Ovis canadensis), and pronghorn antelope (Antilocapra americana) at higher elevations and rabbits (Sylvilagus spp.), hares, and jackrabbits (Lepus spp.), rock and ground squirrels (Spermophilus spp.), pocket gophers (Thomomys spp.), and other small mammals at lower elevations (Cordell 1997, Kantner 2004). Ghost Ranch crews have also identified several mountain-lion tracks in streambeds near the archaeological sites, Puma concolor being the closest thing to competition Homo sapiens has as the region's apex predator.

Small reptiles, amphibians, and birds abound as well. William Degenhardt and colleagues record 123 species of herpetofauna for New Mexico, including salamanders, frogs, toads, turtles, lizards, and nearly 50 taxa of snakes (1996), many of which are present in the area. I myself have observed 30 species of birds while working at Ghost Ranch (Table 2). Fish are relatively scarce in the high desert, with certain exceptions. "Suckers, minnows, dace, and fresh water eels are present in streams," states Fred Wendorf (1953:3). The channel catfish (Ictalurus punctatus) is native to northern New Mexico, as is the cutthroat trout 
(Oncorhynchus clarki), lending credence to the state's reputation as a sport-fishing paradise

(Koster 1957, Page \& Burr 1991).

Table 2: Birds of Ghost Ranch and North-central New Mexico

\begin{tabular}{|c|c|}
\hline Common Name (Scientific Name) & Common Name (Scientific Name) \\
\hline 1. Lesser Goldfinch (Carduelis psaltria) & 16. Barn Swallow (Hirundo rustica) \\
\hline $\begin{array}{l}\text { 2. Broad-tailed Hummingbird (Selasphorus } \\
\text { platycercus) }\end{array}$ & $\begin{array}{l}\text { 17. Dark-eyed Junco (Oregon form) (Junco } \\
\text { hyemalis) }\end{array}$ \\
\hline $\begin{array}{l}\text { 3. Black-chinned Hummingbird (Archilochus } \\
\text { alexandri) }\end{array}$ & $\begin{array}{l}\text { 18. Western Wood-pewee (Contopus } \\
\text { sordidulus) }\end{array}$ \\
\hline 4. Rufous Hummingbird (Selasphorus rufus) & 19. Western Kingbird (Tyrannus verticalis) \\
\hline 5. Lark Sparrow (Chondestes grammacus) & 20. Canyon Towhee (Pipilo fuscus) \\
\hline 6. Tree Swallow (Tachycineta bicolor) & 21. White-winged Dove (Zenaida asiatica) \\
\hline 7. Mountain Bluebird (Sialia currucoides) & 22. Chipping Sparrow (Spizella passerina) \\
\hline 8. Western Bluebird (Sialia mexicana) & $\begin{array}{l}\text { 23. Red-shafted Northern Flicker (Colaptes } \\
\text { auratus) }\end{array}$ \\
\hline 9. Say’s Phoebe (Sayornis saya) & 24. Canyon Wren (Catherpes mexicanus) \\
\hline $\begin{array}{l}\text { 10. Violet-green Swallow (Tachycineta } \\
\text { thalassina) }\end{array}$ & 25. Cassin's Kingbird (Tyrannus vociferans) \\
\hline $\begin{array}{l}\text { 11. Pinyon Jay (Gymnorhinus } \\
\text { cyanocephalus) }\end{array}$ & 26. Steller's Jay (Cyanocitta stelleri) \\
\hline $\begin{array}{l}\text { 12. Ash-throated Flycatcher (Myiarchus } \\
\text { cinerascens) }\end{array}$ & $\begin{array}{l}\text { 27. Evening Grosbeak (Coccothraustes } \\
\text { vespertinus) }\end{array}$ \\
\hline 13. Killdeer (Charadrius vociferus) & $\begin{array}{l}\text { 28. Yellow-headed Blackbird } \\
\text { (Xanthocephalus xanthocephalus) }\end{array}$ \\
\hline 14. Common Raven (Corvus corax) & 29. Black-billed Magpie (Pica hudsonia) \\
\hline $\begin{array}{l}\text { 15. Cliff Swallow (Petrochelidon } \\
\text { pyrrhonota) }\end{array}$ & $\begin{array}{l}\text { 30. Western Scrub Jay (Aphelocoma } \\
\text { californica) }\end{array}$ \\
\hline
\end{tabular}

All birds observed by the author at Ghost Ranch or in the area, in order of first sighting.

Persistence of game patterns

Coarse-grained estimates of the region's carrying capacity for game are made feasible

by the long-term stability of paleoclimatic data, as noted above. Archaeological and early

historic evidence suggest that, under recent Holocene conditions, the Northern Rio Grande is 
naturally rich in game birds and mammals, allowing for periods of regeneration necessitated by overhunting, most likely by refugial mountaintop populations or, within memory, through scientific management techniques. This pattern of hunting, hunting pressure, and at least partial regeneration is evident at the Sand Canyon Pueblo III sites in the northern San Juan Basin (A.D. 1150-1300) (Driver in Varien \& Wilhusen, eds., 2002) and at Arroyo Hondo (A.D. 1300-1425), where mule deer "was the most significant animal resource" (Lang \& Harris 1984:128).

The pioneer accounts of Anglo-American traders and settlers are consistent with this pattern. Writing in the 1840 s, Josiah Gregg reported that an early visitor to the area, Elisha Stanley, witnessed an abundance of large game in northern New Mexico during the 1820s. But as Gregg himself observed, "Elk and deer are also to be met with, but not in large quantities" (in Moorhead, ed., 1974 [1844]:138). Shortly thereafter, S.W. Woodhouse, surgeon-naturalist of the Sitgreaves Expedition, noted that most large animals in northern New Mexico were domesticates, and that wild game was relatively scarce, with the exception of a scatter of pronghorn herds on the eastern prairie (in Wallace \& Hevly, eds., 2007 [1851]). The picture was bleaker still in 1931, when in his report on the mammals of New Mexico for the U.S. Department of Agriculture, Vernon Bailey documented the widespread disappearance of mule deer and other game species in the northern parts of the state:

"In the valleys, especially in the more settled part, they have become very scarce or have entirely disappeared through persistent hunting. In northwestern New Mexico, in the Navajo country, they are conspicuously absent, as are antelope and other game not protected by the religious beliefs of these hunting Indians" (1931:29).

Scientific assessments from the Neal Deal era are seconded by insights contained in New Mexico's rich ethnohistoric library: "The herds of deer of the old days have vanished," 
reported one 1939 informant on traditional Hispano-population hunting practices (in Rebolledo \& Márquez, eds., 2000:193).

The recent recovery of major game species - northern New Mexico is now a prime destination for elk hunting (Airhart 2012) - suggests not only the efficacy of conservation ideology and practice, but also the suitability of climate and ecology in the Northern Rio Grande for low-pressure game collection by small human populations (Findley 1987, Henderson \& Harrington 1914).

Culture as history: the Rio Chama Valley

Rightly or wrongly, human prehistory in New Mexico begins with Clovis, the North and Central American stone-tool complex named for artifacts discovered at the Blackwater Draw archaeological site near Clovis, New Mexico during the 1930s (Cordell 1997) and which dates to 13.5-12.9 kya (cal). Clovis peoples were hunter-gatherers, focused on the diminished megafauna of late Pleistocene America, as well as a grab bag of smaller game animals and mostly unprocessed plant resources (Fagan 2005). There is some evidence of both PaleoIndian and megafaunal presence in the Piedra Lumbre Basin, though never in conjunction (GRAB 2010, Haecker 2003). Later PaleoIndian cultures include Folsom and Cody, regionally centered traditions that targeted Bison antiquus and other plains game, while leaving behind lithic traces in northern New Mexico (Agogino \& Hibben 1958, IrwinWilliams in Ortiz, ed., 1979, Riley 1995).

Oshara Archaic

What followed the late Paleo cultures was a new adaptation, called Archaic today. Evident by 7,500 years ago, the Archaic adaptation evolved as a mixed plant-and-small-game subsistence in response to the gradually warming climate and extinction of the last 
mammoths, mastodons, camelids, and other supersized mammals. It can be viewed both as one part of a kin-centered, global adaptation of Homo sapiens during the early Holocene (Johnson \& Earle 2000) and as a region-specific Oshara Tradition, which Cynthia IrwinWilliams postulated as an in-migration to the northern Southwest following a post-Cody hiatus (in Ortiz, ed., 1979; contra Jennings \& Norbeck 1955). She went on to construct a five-stage Archaic chronology - Jay, Bajada, San Jose, Armijo, and En Medio - that continues in use in the Rio Chama Valley today (Vierra in Minnis \& Redman, eds., 1990).

Bracket dates for the Archaic, 5,500 B.C.-A.D. 400, are derived from features of the adaptation and therefore can vary from one culture-region to the next. ${ }^{2}$ Bruce Huckell defines the start point as the widespread appearance of grindstones in lithic assemblages, designating increased investments in plant processing, and the end point as the appearance of pit-house villages, signifying the sedentism of an expanding population. Alternately, the Archaic can be seen as the hunter-gatherer adaptation to a modern climate that begins with the Holocene and finishes with the rise of field-centered agriculture (Huckell in P. Fish \& Reid, eds., 1996, Huckell 1996, Vierra in Powers, ed., 2005). Hence, the story of the Southwestern Archaic is the story of humans gradually incorporating more and more plant resources into their subsistence, alongside the animal resources that they had hunted for millennia. The botanical innovation - achieved in a region with little or no promise for animal husbandry - had the single great advantage of biological efficiency: it collected food-energy closer to its ultimate source, the sun (Stuart 2009).

\footnotetext{
${ }^{2}$ More than one commentator has joked that the Archaic period, taken as a whole, is the long-awaited solution to the theoretically necessary but archaeologically invisible "BasketMaker I" conundrum of Alfred Kidder's Pecos Classification (Huckell 1996).
} 
Archaic lifeways were based on mobility. Hunter-gatherers chose investments in movement - to, from, and around resource patches, whether for food, fuel, or tools - over investments in place (Higgs \& Vita-Finzi in Higgs, ed., 1972, Jochim 1981). Sand dunes, canyon mouths, and cliff sides served as naturally occurring windbreak architecture. In the American Southwest, Archaic populations approximated a seasonal round that put them in lowland sites collecting plants and small game during spring and summer (or fall) months, and in upland locations during fall and winter (or spring), harvesting mast and large game (Huckell 1996, Vierra in Minnis \& Redman, eds., 1990). Recent research suggests that procurement ranges were larger than once suspected (Shackley in Roth, ed., 1996); nevertheless, as populations multiplied over time, territories contracted, creating resource pressure and incentives for intensification, innovation, and aggregation (Huckell in P. Fish \& Reid, eds., 1996, Kearns in Reed \& Reed, eds., 1992, Kohler, et al, 2008).

The seasonal round was dynamic in nature, and considerable variation can be glimpsed in the archaeological record (Upham 1984, Vierra, et al, in Bousman \& Vierra, eds., 2012, Young 1994). The Southwestern version appears to have evolved in place through time, moving from residential mobility in the Early Archaic to logistical mobility and quasisedentism in the Late Archaic, with the introduction of cultigens by 2000 B.C. or earlier (Simmons 1986, Wills in Price \& Gebauer, eds., 1995). The growth of the agricultural portion of Archaic subsistence, with its ties to sedentism, can be ascertained by using pit structures as a proxy measure for degrees of mobility and rootedness (Gilman 1997). The changeover to farming did not occur everywhere at once (Fagan 2005, Whalen 1994), but only at those sites that favored a cultural package involving stable climates, intensified food production, dominant crops, and storage technology - "a complex suite of adaptive practices" 
(Dean, et al, 1985:550). Hunt-and-gather behavior persisted in many areas, either as a majority lifeway or as the resource foraging of small task groups (Hudspeth in Acklen, ed., 1997, Szuter \& Bayham in Kent, ed., 1989). The Piedra Lumbre Basin is representative of these areas (Vierra \& Ford in Vierra, ed., 2007).

Late Prehistoric and Pueblo periods

By A.D. 400, peoples of the northern Southwest had become inhabitants of places rather than sojourners on landscapes. They grouped together in permanent structures on the San Juan Basin, leaving the Rio Grande region, with its tributaries, for Archaic remnants and intermittent resource collection. Evidence for Anasazi penetration of the Rio Chama Valley during the Developmental Period (A.D. $600-1200)^{3}$ is sketchy at best $-\mathrm{a}$ few projectile points, a bit of pottery (Doyel \& Lekson in Doyel, ed., 1992, Lister \& Lister 1981, Maxwell 2000). Populations grew in the $13^{\text {th }}$ - and $14^{\text {th }}$-centuries A.D. with the construction of small pueblos such as the Palisade Ruin (report to United Presbyterian Church, n.d.), the Riana Ruin near Abiquiu Dam (Hibben 1937), and the larger Leaf Water site in the Lower Rio Chama Valley (Luebben in Wendorf, ed., 1953).

Expansion peaked during the Classic Period (A.D. 1325-1600), combining local growth with Anasazi resettlement from the San Juan Basin, encompassing Chaco, Mesa Verde, and other locales in southern Colorado (Figure 2). The period sites excavated at Poshuouinge, Sapawe, Howiri, and other locations were likely home to Tewa-language populations (Hewett 1906, Jeancon 1923, Mera 1934, Ortman 2012, Skinner 1965, Wendorf in Wendorf, ed., 1953). "The Tewa...spread into a larger area that probably included the

\footnotetext{
${ }^{3}$ Introduced in the 1950s, Fred Wendorf and Erik Reed's Northern Rio Grande chronology has partially supplanted the Pecos Classification for a region with a somewhat different late prehistoric trajectory than the San Juan Basin (Cordell in Cordell \& Gumerman, eds., 1989).
} 
Chama region, Española Basin, and Pajarito Plateau, as well as much of the land surrounding Santa Fe," writes Severin M. Fowles (in Adams \& Duff, eds., 2004:18-9). A late florescence near Ojo Caliente was characterized by innovative hydrological techniques unique to the region (Buge in S. Fish \& P. Fish, eds., 1984, Maxwell \& Anschuetz in Killion, ed., 1992, Wiseman \& Ware 1996).

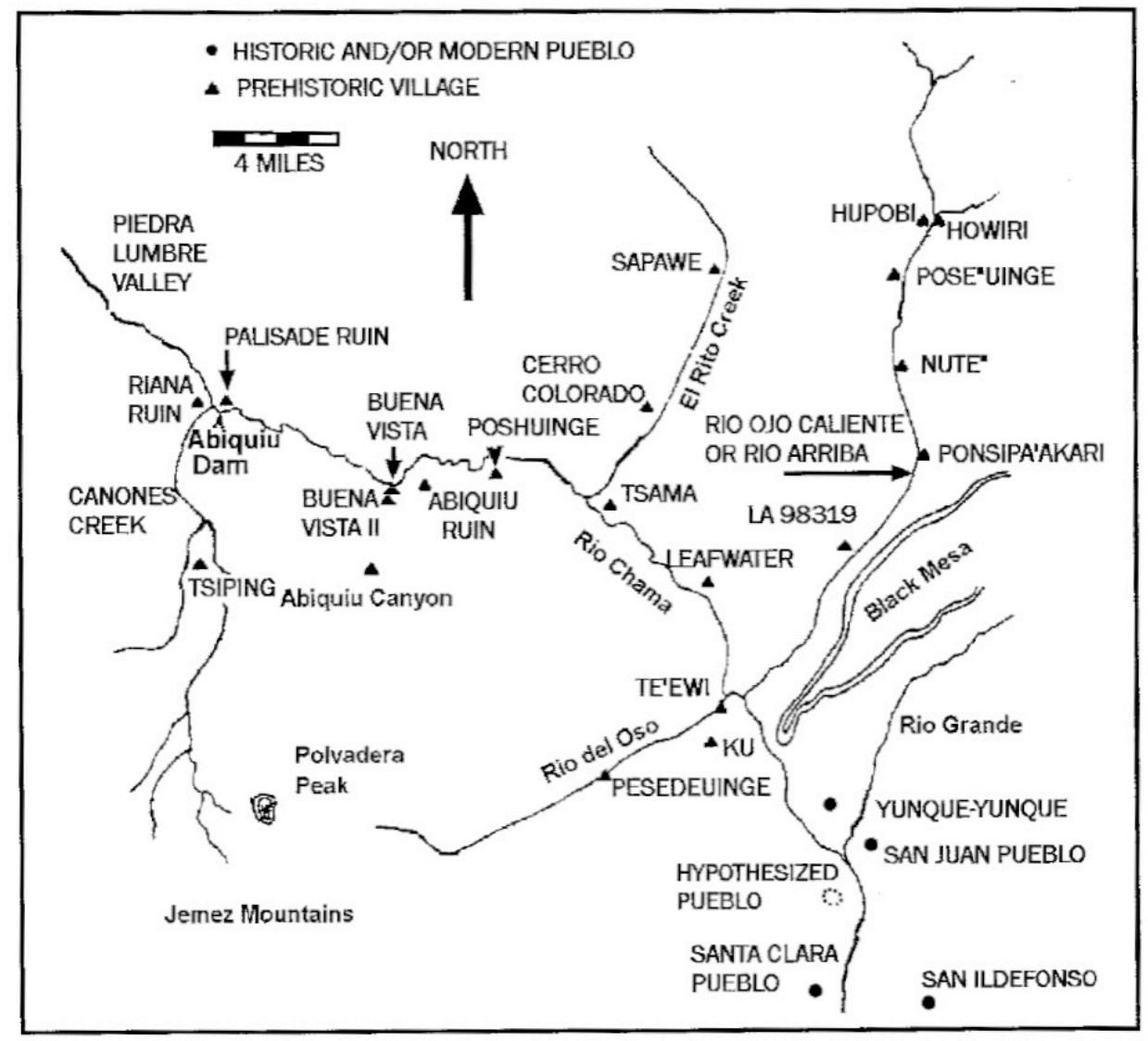

Figure 2. Pueblos of the Northern Rio Grande (ca. A.D. 1250-1500). Ghost Ranch is located northwest of the Palisade and Riana Ruins, in the Piedra Lumbre Valley. Source: Schaafsma 2002:192 (adapted from Beal 1987).

Tracing a pattern found elsewhere in the Four Corners region, the local inhabitants largely abandoned the Rio Chama Valley by moving downriver to the Rio Grande pueblos prior to the Spanish Entrada (Cordell in Cordell \& Gumerman, eds., 1989, Maxwell 2000, 
Varien in Kohler, et al, eds., 2010). "In the Chama River drainage...80 percent of the protohistoric villages appear to have been abandoned between about 1500 and 1525, judging from the surface ceramics and available tree-ring dates," write Haas and Creamer (in Vierra, ed., 1992:26). Populations in the nearby Valles Caldera and Pajarito Plateau followed broadly similar scripts (Anschuetz in Anschuetz \& Merlan 2007, Stuart \& Gauthier 1988). ${ }^{4}$

Three more episodes of culture-history in the Rio Chama region merit mention. Gallina settlements, excavated by Florence Hawley Ellis and Ghost Ranch crews at Turkey Springs and Rattlesnake Ridge, document a late prehistoric incursion of a descendent population originating from somewhere on the San Juan Basin. There is considerable disagreement about the cultural practices and affiliations of these people but less so about their ultimate disposition, as one element of the historic Towa culture at Jemez (Bremer \& Burns in Vierra, ed., 2013, Cordell in Ortiz, ed., 1979, Ellis 1988, Stuart \& Gauthier 1988).

Following Gallina and other large-scale abandonments, Southern Athapaskan peoples, including those who became the Navajo, entered the region (Wilshusen in Scheiber $\&$ Mitchell, eds., 2010). The salvage archaeology that preceded the construction of the Abiquiu Reservoir focused on sites dated to a putative Piedra Lumbre phase (A.D. 16401710) of the Navajo chronology. The attribution of these early sites to a pre- or early Navajo has not gone uncontested (Hogan 1989, Reed \& Horn 1990, Schaafsma 2002, Wilcox in Wilcox \& Masse, eds., 1981, Wozniak 1992). ${ }^{5}$

\footnotetext{
${ }^{4}$ Like most regional-scale phenomena, abandonment turns out to be more complex than it first appears (Cordell 1997). Ramenofsky and Feathers used luminescence dating of surface ceramics to show that a rump habitation may have remained in the Rio Chama Valley until A.D. 1680, the time of the Pueblo Revolt (2002).

${ }^{5}$ There is also evidence for Jicarilla Apache encampments in the area (Haecker 2003).
} 
Finally, the Piedra Lumbre Basin saw the livestock and horse-rustling activities of Ute raiding parties in the historic period, after the Navajo adoption of pastoralism (GRAB 2010, Opler in Linton, ed., 1940, Weisiger 2004). Writes Albert Schroeder:

“...[F]rom the early 1700 's to 1746 , Ute raids extended into Navajo country as far south as Canyon Largo and into Pueblo country south to Jemez and Cochiti and east to Taos. By the end of this period, Southern Utes had expanded their holdings in New Mexico, having displaced Navajos from the region north of Canyon Largo and having taken up residence in camps above Abiquiu on the Chama River" (1965:73).

Writing as history: Spanish arrival and aftermath

History in the vivid sense of contact with the outside world arrived with Coronado's expedition to the American South- and Midwest in A.D. 1540-42. The Spaniards and their native Mexican allies reached the Northern Rio Grande in 1540, where political division among local Pueblo Indian groups undermined efforts at dissuasion and resistance (Riley 1995). History in the mundane sense of documents and records began with Spanish writers such as Pedro de Castañeda, the chief chronicler of the Coronado expedition (ibid., Schaafsma 2002).

New Mexico became part of Spain's New World empire, a loosely governed periphery subject to fits of upheaval and revolt, until Mexico gained independence from Spain in 1821. Mexico's northern territories, including New Mexico, passed into American hands at the conclusion of the Mexican-American War in 1848. The U.S. conquest was presaged by the American penetration of the Northern Rio Grande by merchants and explorers such as Josiah Gregg, via the Santa Fe Trail (Moorhead, ed., 1974 [1844]).

Present-day New Mexico began rounding into form on its ascension into territorial status with roughly recognizable political boundaries in the years following the American Civil War. By 1900, Rio Arriba County had 13,177 inhabitants, 175 miles of railway, and 
significant commercial investments in mining, lumbering, and animal husbandry, as well as a 415,000-acre Jicarilla Apache Reservation "upon which are 830 Indians making rapid advance," according to Frost and Walter in a recruitment volume for the territory's Bureau of Immigration (1904:221). They also note that, "[The Northern Rio Grande] is one of the richest archaeological fields on this continent" (ibid.:127). In 1912, New Mexico entered the union as the $47^{\text {th }}$ and second to last state in the continental U.S.

\section{Archaeology at Ghost Ranch}

Ghost Ranch forms a special case of Piedra Lumbre archaeology. Privately owned by the Presbyterian Church (USA) in Louisville, Kentucky, the ranch has a long and colorful history that began more than one hundred years ago with the cattle-rustling Archuleta brothers (nicknamed "Los Animales"), ${ }^{6}$ and continued through the $20^{\text {th }}$ century as a dude ranch and vacation getaway for wealthy Easterners and Hollywood film stars, under the initial direction of Carol Bishop Stanley and, starting in 1935, magazine writer and editor, Arthur Pack. Along the way, it became noted as an inspiration for O'Keeffe's paintings and for the early dinosaur finds, such as Coelophysis bauri, of paleontologist, Edwin H. Colbert, and others. Pack donated the ranch to the Presbyterian Church in 1955, which has made it into a conference and education center (Pack 1979, Poling-Kempes 1997 \& 2005).

Florence Hawley Ellis founded the Ghost Ranch Archaeological Seminar in 1972, following the chance discovery of prehistoric pottery on a class outing to the Turkey Springs lava beds. The Archaeological Seminar is the longest-running educational program offered by the ranch, having celebrated its $40^{\text {th }}$ anniversary in the summer of 2011 (Ghost Ranch

\footnotetext{
${ }^{6}$ The brothers' idea of fraternal relations was apparently based on Cain and Abel, with one eventually killing the other in a fight over money. During their time at the ranch, it was known as el Rancho de los Brujos - Ranch of the Witches. Later occupants changed the name to Ghost Ranch (Poling-Kempes 2005).
} 
Journal n.d., Muceus, pers. comm., Poling-Kempes 2005). Participants survey, excavate, and curate archaeological finds, which are stored and publicly displayed at the ranch's museum facilities. The seminar was under the direction of Cheryl Muceus, until her retirement from Ghost Ranch in 2012.

Chronology and dates

In one of the reigning ironies of the Northern Rio Grande, culture-history nomenclature is more settled than the cultures themselves. In analyzing the remains from Ghost Ranch sites, I utilize standard archaeological timescales:

Table 3: Chronology

\begin{tabular}{|c|c|c|c|}
\hline Era & $\begin{array}{l}\text { Willey-Phillips } \\
\text { Equivalent }\end{array}$ & Phase & Dates \\
\hline PaleoIndian & Lithic & & $>5500$ B.C. \\
\hline \multirow[t]{5}{*}{ Oshara Archaic } & Early Archaic & Jay & 5500-4800 B.C. \\
\hline & & Bajada & 4800-3300 B.C. \\
\hline & Middle Archaic & San Jose & 3300-1800 B.C. \\
\hline & & Armijo & 1800-800 B.C. \\
\hline & Late Archaic & En Medio & 800 B.C.-A.D. 400 \\
\hline \multirow[t]{4}{*}{ Northern Rio Grande } & Formative & Developmental & A.D. $600-1200$ \\
\hline & & Coalition & A.D. $1200-1325$ \\
\hline & Classic & Classic & A.D. $1325-1600$ \\
\hline & Post-classic & Historic & A.D. 1600-present \\
\hline \multicolumn{4}{|c|}{$\begin{array}{l}\text { Oshara Archaic: Irwin-Williams in Ortiz, ed., 1979. Northern Rio Grande: Wendorf \& } \\
\text { Reed 1955. Willey-Phillips stages: Willey \& Sabloff 1993. For convenience's sake, I am } \\
\text { grouping the two-century gap between Oshara and Northern Rio Grande with Irwin- } \\
\text { Williams's transitional En Medio phase (Late Archaic). }\end{array}$} \\
\hline
\end{tabular}

GR-2 has produced a wide variety of dates, from late Paleo to recent historic, based on human script, dendrochronology, radiocarbon, and obsidian-hydration analysis. The most recent date is a graffito scratched into the site's sandstone cliff face that reads "Nikolas 
Lovato, Avril 1916.” The oldest date is 8065 BP (6115 B.C.), from a wood-charcoal sample excavated by Joe Wright and myself during the 2007 season. GR-145's range is considerably narrower: radiocarbon dates from the 1996,1998, and 2012 seasons span the period of 200 B.C.-A.D. 1660, the Late Archaic to the early Historic phase of the Northern Rio Grande timescale (Binggeli, et al, n.d., GRAB 2009, Hayden, pers. comm., Muceus, pers. comm., Wendorf \& Reed 1955).

Theoretical framework

Archaeological research requires a theoretical framework. Facts and theory - that is, data and an intellectual context for relating data in a meaningful way - cannot be considered in isolation, only to be forced together, in a kind of shotgun wedding, when the investigator finds it convenient to arrange one (Hodder 1999). "Theory is much more than the abstract ideas jawed over in a graduate seminar: It is the foundation for productive archaeological research," argue Black and Jolly (2003:21). I want to close this section by laying out a general theoretical framework for analysis and interpretation.

In recent decades, two major schools of thought have dominated American archaeology. The first, a mid- $20^{\text {th }}$ century movement called the New Archaeology or processualism, sought to place a discipline with deep roots in the liberal arts on a more scientific footing, by emulating natural-scientific methods in the study of cultural evolution. Processualism also had a negative agenda, rejecting as archaeology's purpose the fixing of culture phases and the collection of pretty objects in museums. Early advocates included Gordon Willey and Philip Phillips, whose 1958 work, Method and Theory in American Archaeology, is seminal. "They felt that explanation must lie in a complex interplay of diffusion, cultural-environmental interaction, demographic change... and psychological 
factors," write Willey and Sabloff (1993:216). Archaeological historian, Bruce Trigger, notes that, under the steady fire of Lewis Binford's polemics, the New Archaeology became firmly entrenched as American practice by the 1960s, with little sustained opposition (1989).

William Harvey Krieger describes as significant processualism's embrace of the philosophy of science, in the form of Carl Hempel's covering-law models (2006). The latter derived his approach, with modifications, from the Weltanschaunng of the 1920s Vienna Circle, which maintained "a belief in science as a unified enterprise, a desire to eliminate metaphysics, and a need for a new definition of philosophy" (ibid.:5). Hempel's ambitious plan to unite social sciences such as history with reductive disciplines such as physics proved vulnerable to the critiques of a later generation of philosophers, including W.V.O. Quine, Karl Popper, Hilary Putnam, and Thomas Kuhn, who demonstrated the epistemological, institutional, and other problems that lay at the heart of the logical-positivist initiative, including its heirs and epigones ("Vienna School," Stanford Encyclopedia of Philosophy, Feb. 15, $2015<$ http://plato.stanford.edu/entries/vienna-circle/\#VerCriMetClaPer $>$ ). At the same time, processualism in the field tended to produce trite generalizations rather than robust scientific insights, in the manner of physics or chemistry. Kent Flannery ridiculed such statements as the "Mickey Mouse laws" of archaeology (in Renfrew \& Bahn 2012:476).

The second major school, the post-processualism of the 1980s and 90s, was an agonistic response to its predecessor. Its best-known advocate was the British archaeologist, Ian Hodder. Hodder rejected the notion that the archaeological record "is grounded in a 'timeless past,' which, in eschewing culture history, seeks a processual explanation of human behavior...through concepts of utility, control, and adaptation" - dynamic but material, even mechanistic, relationships (Willey \& Sabloff 1993:299). Instead “[p]ost-processualism relies 
heavily on historical context and particularity for...it is only in such historical contexts that past behavior can be understood" (ibid.). ${ }^{7}$ Hodder presents the case for archaeology as an internally consistent, evidence-based narrative freed from the pretensions of scientism and a sclerotic devotion to middle-range causation (1999). He has also followed the French historian, Fernand Braudel, in arguing for the usefulness of total history - history plus archaeology - in comprehending the longue durée of cultural evolution (1987).

Post-processualism has generated problems of its own. Many of these derive from the overeager application of English philosopher R.G. Collingwood's method of 'history from inside,' that is, the idea that history can only be understood by entering into the psychological states of its agents and actors (Renfrew \& Bahn 2012). How archaeology can accomplish this feat, absent written records of a personal nature, remains an unanswered question. It becomes far too easy, pursuing this path, to read one's own preoccupations into the ostensible subject of inquiry. Archaeology becomes the backward projection of contemporary concerns, a conquest of the distant past by ideological modes of the present (Willey \& Sabloff 1993).

The fact is, archaeology carries on today as a social science, at a theoretical midpoint between the hard sciences and the humanities. Processualism remains a force, albeit softened by its turn away from Hempel's deductive-nomological method to Karl Popper's less stringent principle of falsification (Krieger 2006, Renfrew \& Bahn 2012). Post-processualism perseveres as well, combining traditional archaeological storylines with the specificity of

\footnotetext{
${ }^{7}$ An example of Hodder's critique is his analysis of Lewis Binford's middle-range theory, which the latter saw as providing causal links between scientifically observed phenomena and the material remains of the past, similar to the ethnographic parallels cited by cultural anthropologists. As Hodder notes, middle-range theory is an operating procedure, with an analogical structure empty of content, scalable to any particular set of archaeological problems. It is therefore unverifiable as a method, and is better described as hermeneutical rather than strictly scientific (1999).
} 
historical context. It is here that I want to suggest a new way of synthesizing their major strengths, as a narrative science in the key of cultural evolution.

Archaeology as narrative science

"Culture is passed down from one generation to another, or, it may be borrowed freely by one tribe from another. Its elements interact with one another in accordance with principles of their own. Culture thus constitutes a supra-biological, or extrasomatic, class of events, a process sui generis."

- Leslie White, The Science of Culture (1949:16)

Humans are unique among living species for exhibiting the hallmarks of complex culture. Following Alvard (2003), Henrich and McElreath (2003), and Richerson and Boyd (2005), I define complex culture as the sum of behaviors and technologies that make possible the intergenerational accumulation of social capital. In this context, "social" extends "capital" to non- or pre-financial assets. Human social capital existed long before the rise of markets, trade, coinage, or credit (e.g., the skills required to make stone or bone tools).

Richerson and Boyd have been persuasive in arguing that the complex culture of Homo sapiens, though founded by Darwinian processes, cannot be reduced to an epiphenomenon of biological evolution (ibid.). This distinctiveness gives culture the coherence of independent trajectory, which can be captured in narrative form, as a thin version of progress, ${ }^{8}$ without the encumbrances of a metaphysical or materialist teleology. I am proposing here that archaeology is uniquely suited to the study of complex culture and its multidirectional evolution among human societies. Archaeology is history by other means, a story with structure and meaning but no discernible orientation or ending. This framework forms the basis for my analysis.

\footnotetext{
${ }^{8}$ An anthropological equivalent is the notion of the expanding household or community base, as presented by Stephen Gudeman in The Anthropology of Economy (2001).
} 


\section{METHODS, MATERIALS, AND ANALYSIS}

Ghost Ranch partakes fully in the archaeological richness of the Piedra Lumbre Basin. Surveys have identified potential dig sites numbering in the hundreds, ranging from evidence for long-use prehistoric campsites to temporary structures built by local pastoralists, many preferentially preserved by the high-desert climate. But if Ghost Ranch offers considerable promise as an untapped archaeological resource, it also presents obstacles for making real that promise.

Ghost Ranch is "an interfaith education and retreat center" with a religiously centered mission of fostering spiritual growth (Ghost Ranch Web site $<$ www.ghostranch.org $>$ ). It has no formal affiliation with a university or scientific organization. Participants in the annual archaeological seminar - many of whom are repeat visitors - are intelligent and competent volunteers with strong feelings for the program and for bringing to life the ranch's remarkable prehistory. But they are amateur rather than professional archaeologists, learning technique on the fly, and are therefore operating without the advantages of academic or expert training in the discipline. This lack of rigorous training and education is sometimes reflected in the quality of data collection and field curation. It is also marks the variations in practice one sees between GR-2 and GR-145. Field crews have considerable leeway in their investigative methods, often playing hunches in the hope of finding interesting features and artifacts, rather than pursuing a standardized approach to data collection and documentation (for a related analysis, see Berggren \& Hodder 2003). 
The inspired but unpolished nature of Ghost Ranch archaeology has played a role in shaping my research. The asymmetrical data sets from GR-2 and GR-145 require an analytical method that takes discrepancies and lacunae into consideration. The method that I have decided on involves a historical approach to the data, combined with appropriate forms of statistical analysis, along the lines advocated by Ian Hodder in The Archaeological Process (1999). I begin with brief introductions to both sites.

\section{Overview of GR-2}

Ghost-Ranch 2, or LA 13674, is a south-facing rockshelter with evidence of intermittent, long-term use "located in...the east pasture of Ghost Ranch on the Bull Canyon drainage, at an elevation of 1,981 m" (Binggeli, et al, n.d.:41). It was one of several potential dig sites discovered by survey teams during the late 1980s, when the focus of the Ghost Ranch Archaeological Seminar shifted from offsite Gallina-culture excavations to the largely unexplored pre-agricultural remains common on ranch property.

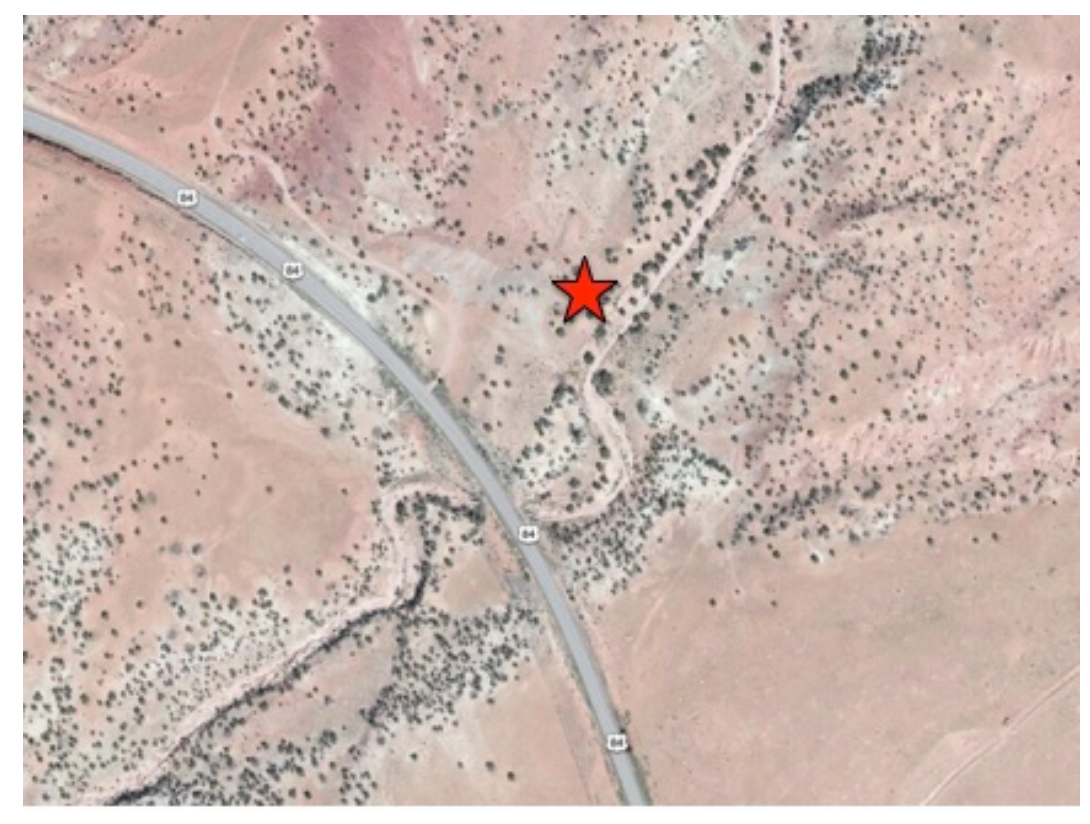

Figure 3. GR-2 is located on the north side of the Bull Canyon Arroyo, near highway 84, southeast of ranch headquarters. Source: Apple Maps (Feb. 18, 2015). 
GR-2 is situated on a plat measuring $18 \mathrm{~m}$ by $13 \mathrm{~m}$. A three- to five-meter high sandstone bench forms the site's northern boundary, which grades gently into the floodplain of Bull Canyon Wash, an intermittent, southwest-running stream in a deep-sided channel. A year-round seep is located nearby. GR-2 is fringed by stands of piñon and juniper, reduced by recent droughts, as well as Cholla, Pale Wolfberry (Lycium pallidum), and various drought-tolerant grasses (ibid., Dunmire \& Tierney 1995).

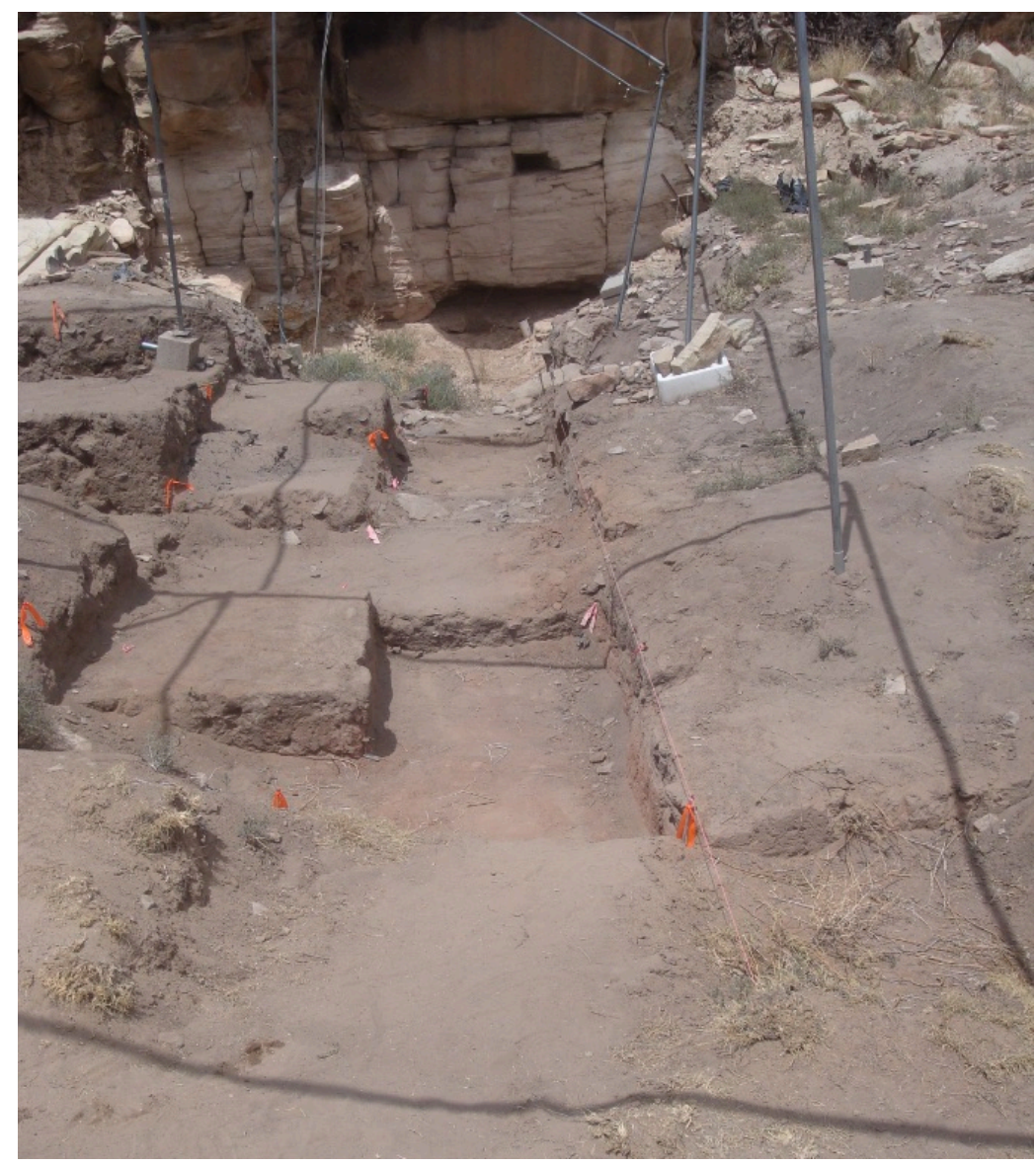

Figure 4. GR-2 viewed from the site's south end. Source: author photo.

Excavation at GR-2 began in 1990, and has been continual since that time. Early finds included the remains of what was likely a sheepherder's hut, with a flagstone floor and the burnt remnants of vigas (roof timbers). Since then, the site has produced a wealth of artifacts and features, including lithics, hearth structures, and ceramics reflective of the region's 
Classic-phase Tewa cultures. Deeper levels reach back to the Archaic; projectile points, lithic debris, grindstones, grinding slabs, fire-cracked rock, and fireplace charcoal are common. Far less common is animal bone (Binggeli, et al, n.d.:43).

In the first 21 seasons, Ghost Ranch crews excavated cultural remains from more than four meters of surface and soil in the site's deepest squares. The late Richard Binggeli was GR-2 crew chief every season that I dug there.

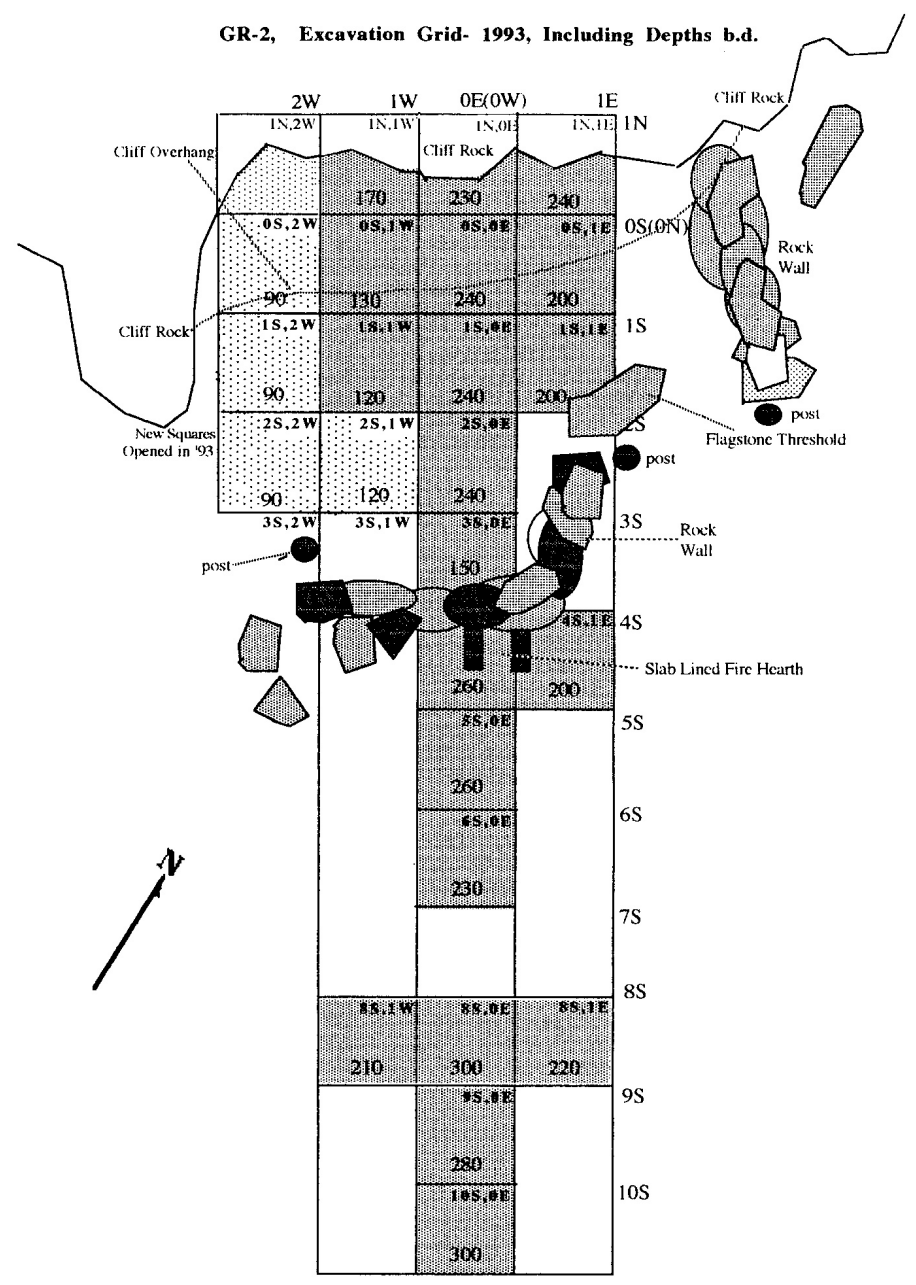

Figure 5, Excavation Grid of GR-2

Figure 5. GR-2 in plan. The excavation grid comprises $401 \mathrm{~m} \times 1 \mathrm{~m}$ squares. Source:

Shibley, et al, n.d. 


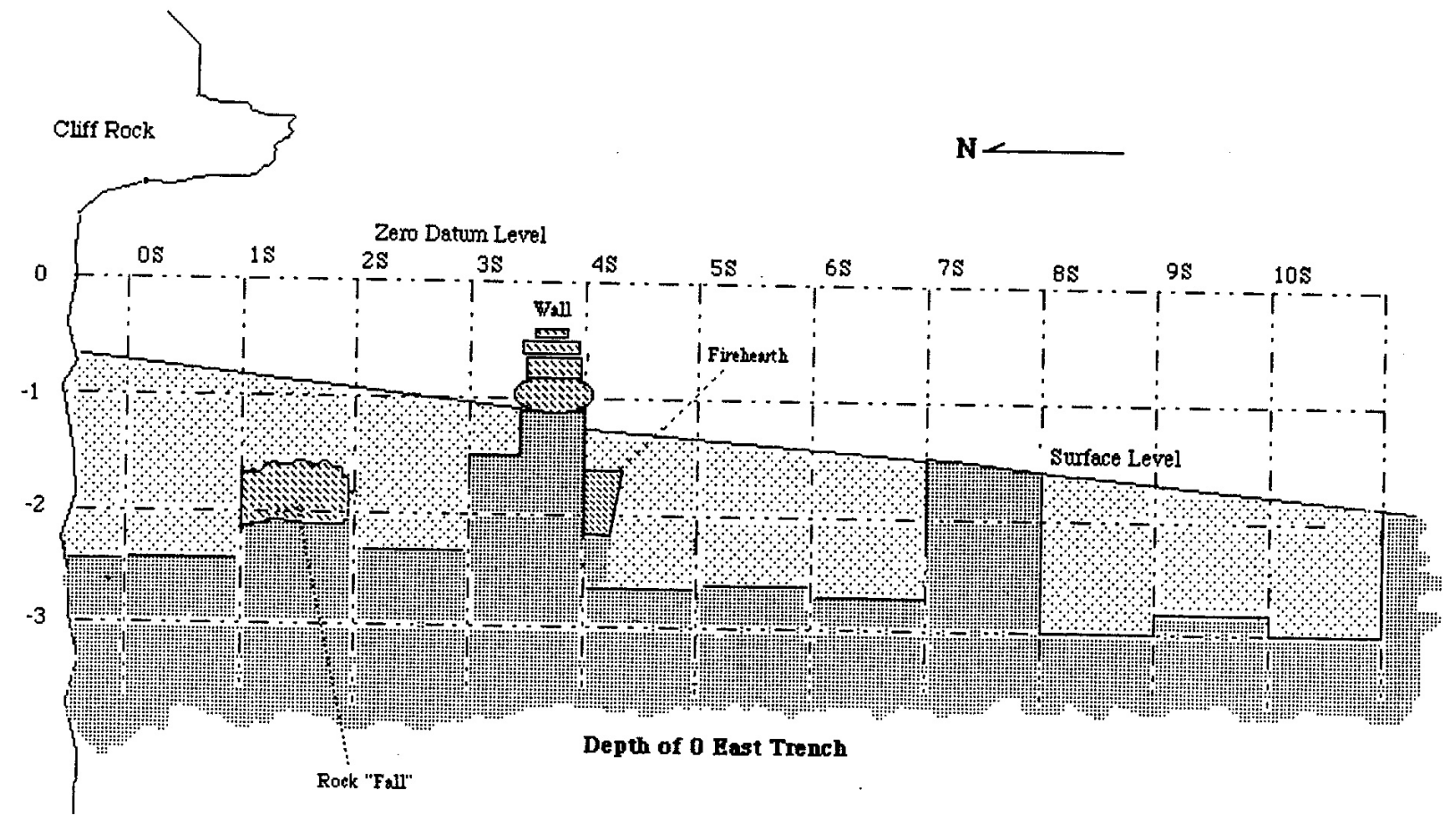

Figure 6. GR-2 in profile. Slope value from north to south boundary ( $L$ to $R)=-0.11(-1.25$ $m / 11.0 \mathrm{~m})$. Source: ibid.

Overview of GR-145

Ghost-Ranch 145, or LA 108340, is a south-facing rockshelter situated on a narrow bench in the Arroyo del Yeso, near ranch headquarters and about five km ( $\approx$ three miles) northwest of GR-2. Located in a high-energy stream channel and within the maximum flood level of the Abiquiu Reservoir, the "Doodlebug" site was selected for excavation in 1995, as a means of rescuing survey-evident cultural material from loss due to erosion, silting, and potentially catastrophic flooding. 


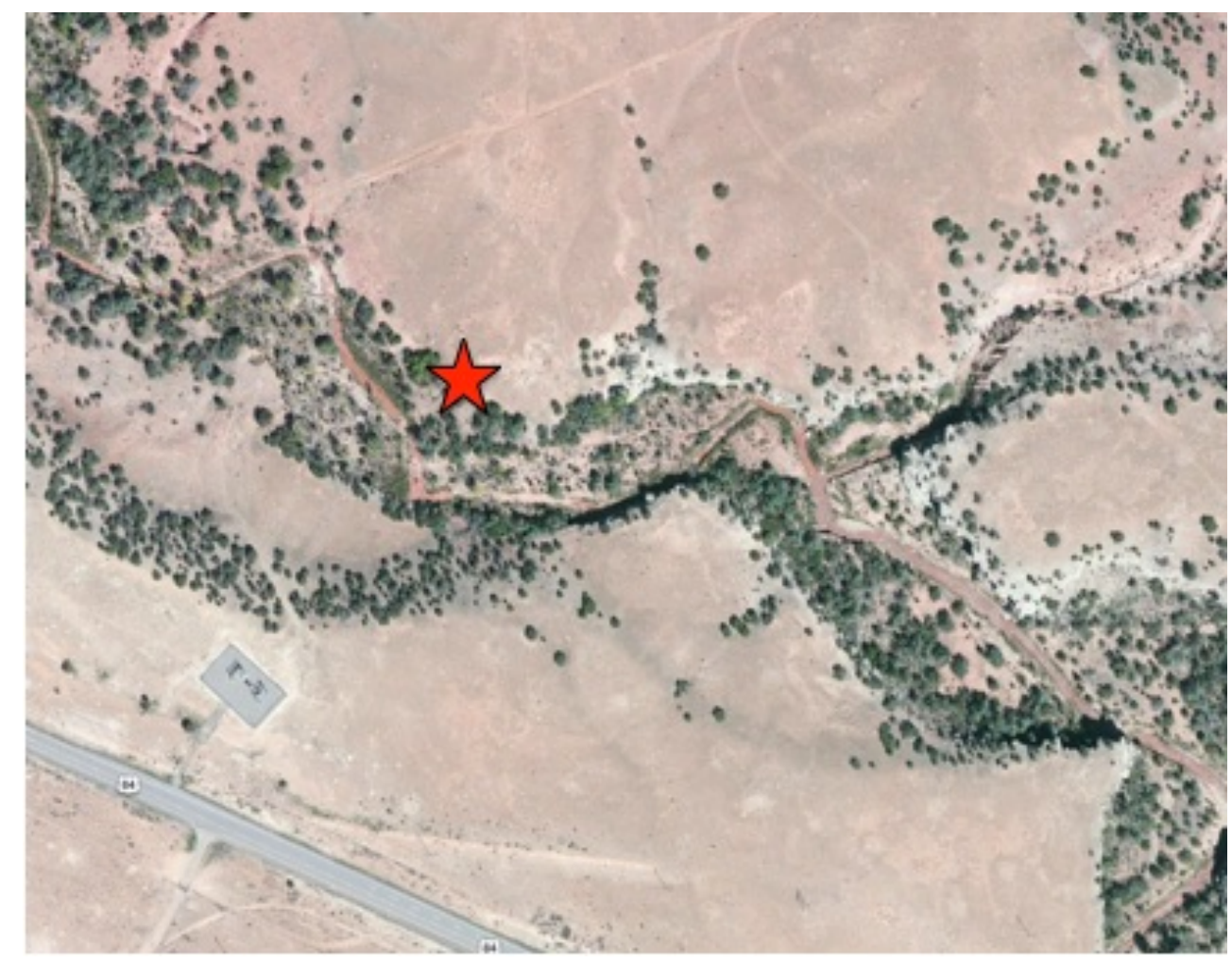

Figure 7: GR-145 is located in the Arroyo del Yeso stream channel near ranch headquarters, about 5 km (3 miles) northwest of GR-2. Source: Apple Maps (Feb. 18, 2015).

GR-145's elevation is equal to that of GR-2: 1,981 $\mathrm{m}(\approx 6,500$ feet $)$. The well-watered site is greener than GR-2, with abundant stands of piñon, juniper, and cottonwood species (Populus spp.) and a diverse array of shrubs, herbs, and grasses (Table 4). Possible cultural features, including tent rings and rock-mulch gardens, exist on the site-capping but unexcavated clifftop (Hayden, pers. comm.). John Hayden is crew chief at GR-145. According to Hayden:

"The site covers most of the surface of the remains of an elevated, dissected bench, that is some 13 feet ( 4.3 meters) above the present stream channel bottom. The long axis of the site parallels the base and face of the northeast to southwest trending sandstone cliff. The cliff provides a protective wall and a slight overhanging shelter along the north side. The site is approximately 110 feet (36 meters) long and 50 feet (16 meters) wide. The surface area of the bench is about 5,000 sq. ft. (290 sq. $\mathrm{m})$... The streamside edge of the bench terminates abruptly to a nearly vertical cut bank" (site report, Jul. 14, 2005). 


\section{Table 4: Botanical Ecology at GR-145}

\section{Tree Species: Common Name (Scientific Name)}

Colorado pine (Pinus edulis) (a/k/a Two- $\quad$ Rio Grande cottonwood (Populus deltoides needle pine) $\quad s s p$. wislizensi $=P$. fremontii $)$

\begin{tabular}{|ll|}
\hline One-seed Juniper (Juniperus monosperma) & Narrowleaf cottonwood (P. angustifolia) \\
\hline Rocky Mountain Juniper (J. scopulorum) & \\
\hline Shrub Species: Common Name (Scientific Name) \\
\hline Skunkbrush sumac (Rhus trilobata) & $\begin{array}{l}\text { Sandbar willow (Salix exigua) (a/k/a Coyote } \\
\text { willow) }\end{array}$ \\
\hline $\begin{array}{l}\text { Stretchberry (Foresteria pubescens) (a/k/a } \\
\text { New Mexico wildolive) }\end{array}$ & Broom snakewood (Gutierrizia sarothrae) \\
\hline $\begin{array}{l}\text { True mountain mahogany (Cercocarpus } \\
\text { montanus) }\end{array}$ & Tree cholla (Opuntia imbricata) \\
\hline Pale wolfberry (Lycium pallidum) & New Mexico locust (Robina neomexicana) \\
\hline $\begin{array}{l}\text { Rubber rabbitbrush (Chyrsothamnus } \\
\text { nauseosus) }\end{array}$ & $\begin{array}{l}\text { Invasive non-native: Saltcedar (Tamarix } \\
\text { ramosissima }=\text { T.pentandra) }\end{array}$ \\
\hline Grasses and Herbs: Common Name (Scientific Name) \\
\hline Blue grama (Bouteloua gracilis) & $\begin{array}{l}\text { Hairy goldenaster (Heterotheca villosa ssp. } \\
\text { villosa) }\end{array}$ \\
\hline Sideoats grama (B. curtipendula) & Galleta (Hilaria jamesii) \\
\hline Louisiana sagewort (Artemisia ludoviciana) & Plains blackfoot (Melampodium leucanthum) \\
\hline $\begin{array}{l}\text { Rose heath (Chaetopappa ericoides) (a/k/a } \\
\text { Baby aster) }\end{array}$ & \begin{tabular}{l} 
American licorice (Glycyrrhiza lepidota) \\
\hline Wild buckwheat (Eriogonum spp.)
\end{tabular} \\
\hline All taxa identified by John Hayden (ibid.). & Scouringbrush horsetail (Equisetum spp.) \\
\hline
\end{tabular}

Like GR-2, GR-145 has produced a multiplicity of features and artifacts associated with Archaic-Era foraging peoples though at shallower time-depths: hearth structures, fireplace charcoal, ashy lenses, lithic remains, and grindstones. That noted, GR-145 has vouchsafed a few unusual finds: two Olivella shell beads, a dacite spear point, and a butchery 
anvil. A significant difference between the two sites is the apparent greater volume of animal bone found at GR-145; neither location has produced any human bone.

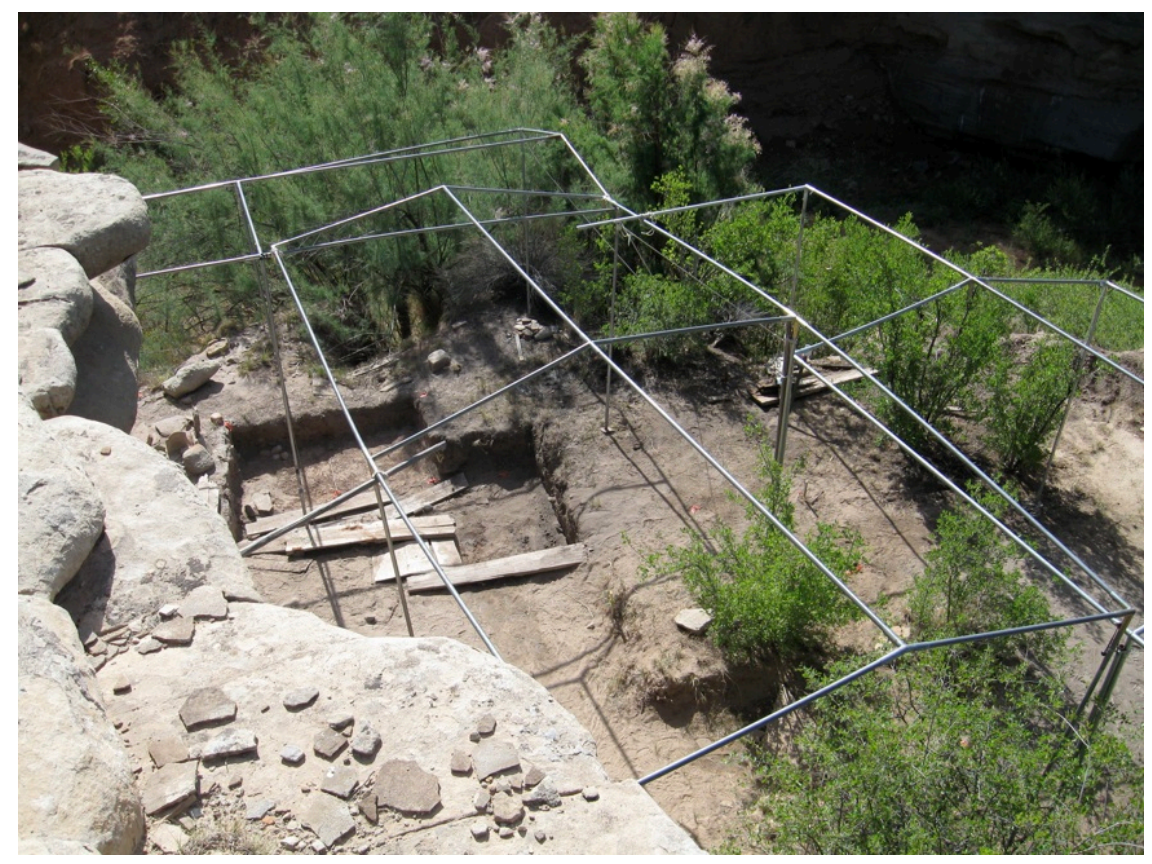

Figure 8: GR-145 viewed from the site's northeast end, atop the cliff. Source: author photo.

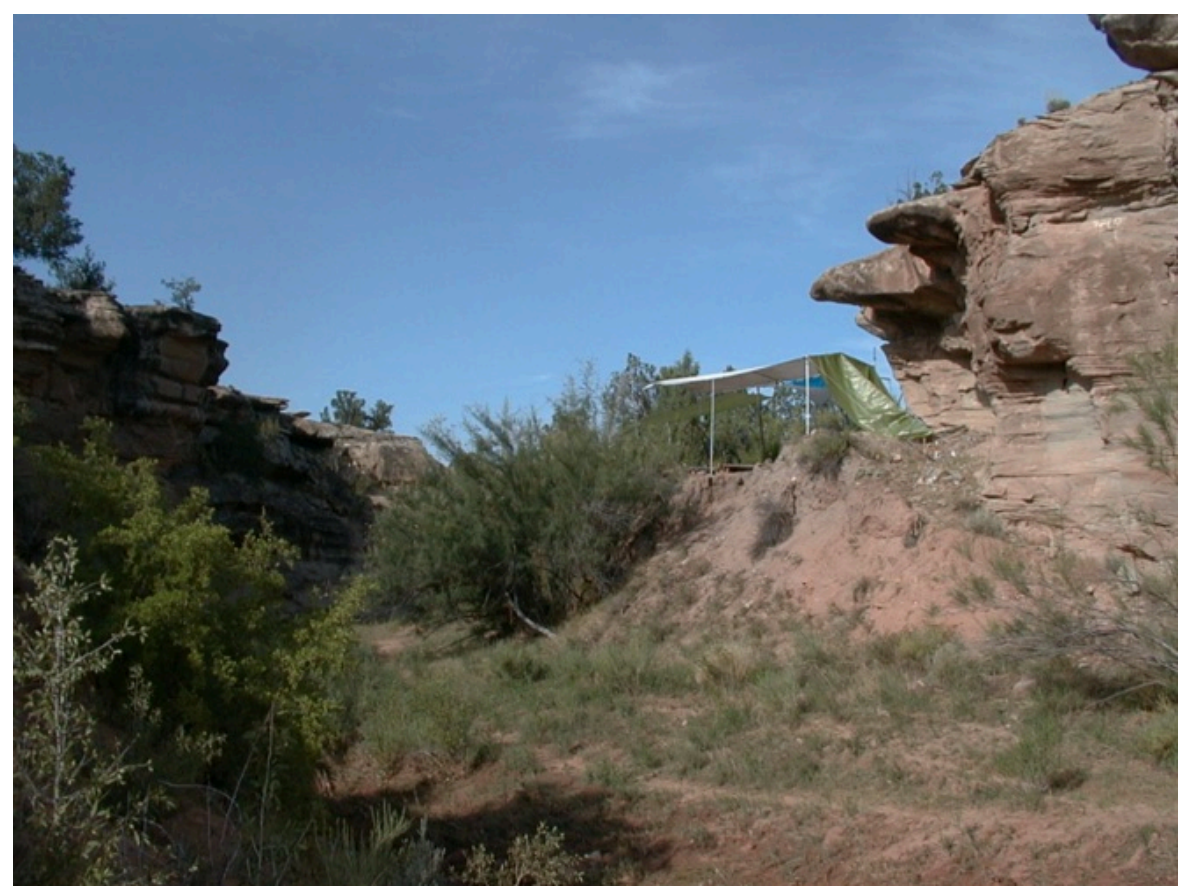

Figure 9: GR-145 viewed from the southwest, in the Arroyo del Yeso streambed. Source: author photo. 
Crews at GR-145 have removed approximately three meters of matrix from the deepest squares at the site since work began in 1995.

Soil description and stratigraphy

No extensive analysis of soil composition or layering has ever been performed at GR2. In place of a detailed investigation, GR-2 field crews have developed an informal understanding of the site's cultural matrix - a kind of "folk stratigraphy." As described by Jim Shibley and colleagues:

"The soil throughout the site [is] soft and ashy in color. The surface soil [is] tan in color...the soil beneath the tan surface layer [is] gray to a depth of somewhat over a meter...At the deepest portion of the excavation, the soil [changes] to a reddish tan, matching the sandstone cliffs of the upper Bull Canyon drainage" (Shibley, et al, n.d.).

This two-part division of gray and reddish soil shot through with charcoal lenses - in essence, a pair of stratigraphic units - is interpreted as cultural soil atop a previous flooddeposited layer (though cultural remains continue to be found in the older alluvial material, albeit in lesser quantities). Dr. Les McFadden, of the University of New Mexico Earth Sciences Department, had confirmed this general impression on visits to GR-2 (pers. comm.).

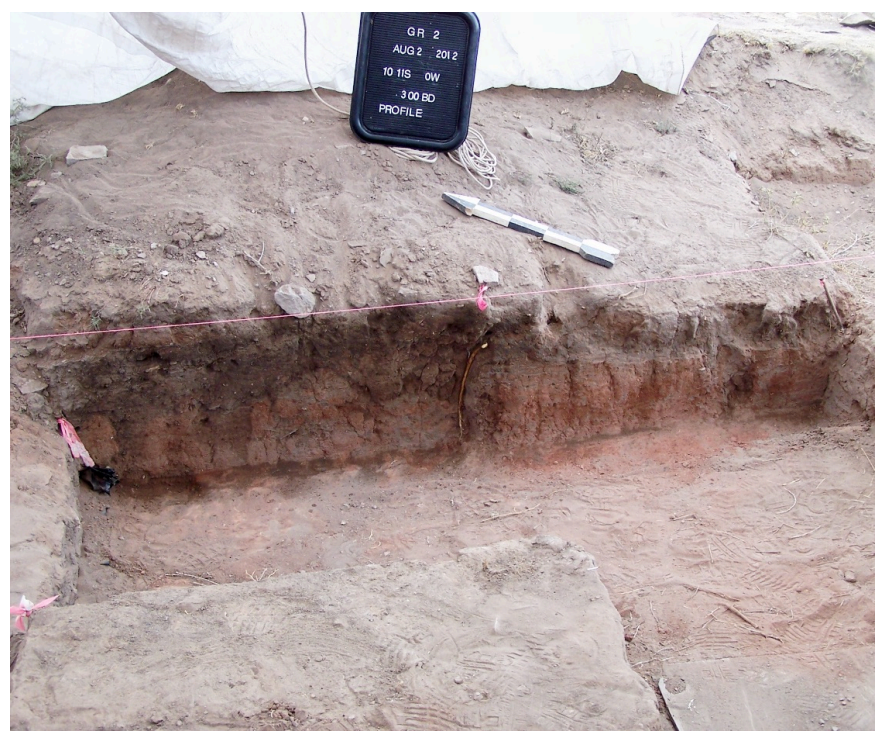

Figure 10. Sample soil profile at GR-2. Source: author photo. 
Stratigraphic information on GR-145 is also slight but John Hayden has provided the

following observation regarding the upper units of the matrix:

"The upper levels (surface to about $30 \mathrm{~cm}$ below) [are] principally sandy alluvial/colluvial soils with occasional evidence of staining and presence of ash and charcoal, which suggest [the] presence of thermal features and activity centers. These [are] often shallow informal basins $20 \times 70 \mathrm{~cm}$ o.a. to $50 \times 100 \mathrm{~cm}$ o.a...The next lower layers ( 31 to $120 \mathrm{~cm}$ below the surface) have definite strata. In these layers at least two activity levels have been identified. An activity level is a surface (uppermost part of a stratum) that exhibits the effects of compacting, staining, littering, or other modification due to human activities. The two activity levels are located approximately $30 \mathrm{~cm}$ and $50 \mathrm{~cm}$ below the surface. Major features, in our case thermal features, are believed to be directly associated with the levels" (site report, Jul. 14, 2005).

Hayden also notes the dynamic nature of site-formation and -deformation processes at GR-145, which balances colluvial deposition from clifftop runoff with the mixed alluvial and wrecking action of midsummer monsoonal torrents in the Arroyo del Yeso (ibid.).

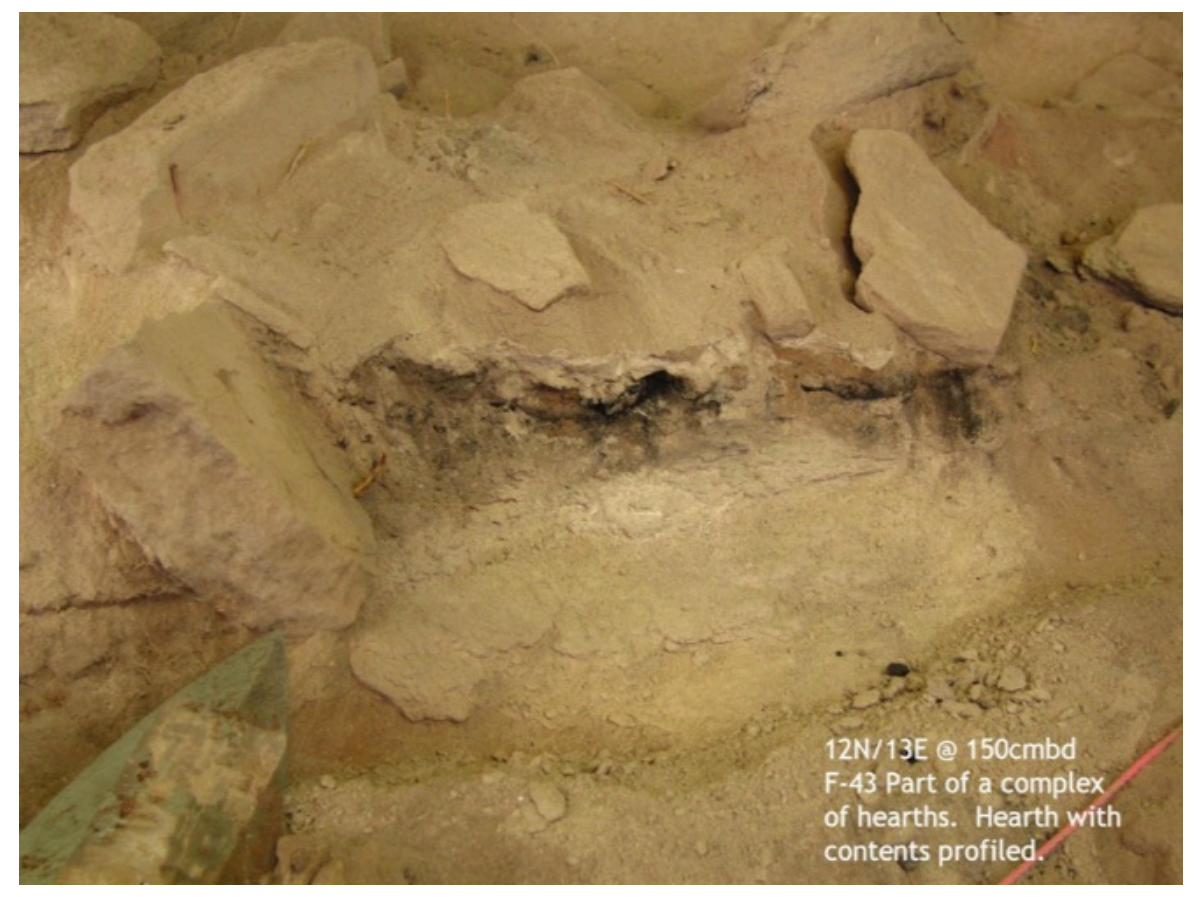

Figure 11. Sample soil profile at GR-145. Charcoal lenses, often categorized as "thermal features," are common at the site, which has fewer structured hearths than GR-2. Source: John Hayden photo. 
Soil tests: $\mathrm{pH} \&$ phosphates

Soil is the primary medium of archaeological inquiry, creating both the preservative environment and associational context required for prehistoric investigation (Banning 2000). "Soil science... and archaeology are closely allied in temporal and spatial scales," writes Vance T. Holliday, seeing in pedology the geologic discipline most in harmony with human culture making (in Stein \& Linse, eds., 1993:29). Pedologists define soil "as an organized natural body" with diverse and dynamic impacts on the objects that it supports, transports, or surrounds (Fanning \& Fanning 1989:2). Characterizing archaeological soils can be critical to understanding issues of differential preservation (Banning 2000, Stiner, et al, 2001).

In 2011 and 2012, I performed two types of tests on soil samples from the Ghost Ranch sites. The first involved identifying the degree of alkalinity or acidity in 15 samples from GR-2 and GR-145 - an estimate of preservational quality. "pH is a measure of the concentration of hydrogen ions in the sediment, along a scale from 0 to 14 such that numbers less than 7 indicate acidity and ones higher than 7 indicate basic (alkali) material," writes E.B. Banning (ibid::241). Acid soils are especially destructive of bone; alkaline soils much less so (Gordon \& Buikstra 1981). To conduct my tests, I purchased and calibrated a pH meter from a scientific-supply firm (Banning 2000, Lambert 1997, Sobolik 2003).

The results of the $\mathrm{pH}$ tests are shown in Table 5:

Table 5: GR-2 pH Test Results

\begin{tabular}{lllll}
\hline \multicolumn{2}{l}{ Field Specimen \#/Year } & Grid Location & Depth (cmbd) & $\mathrm{pH}$ \\
1. & FS \#15-2012 & $7 \mathrm{~S} / 1 \mathrm{~W}$ & $190-220$ & 9.4 \\
2. & FS $\# 74-2011$ & $6 \mathrm{~S} / 2 \mathrm{~W}$ & 180 & 8.4 \\
3. & FS $\# 72-2011$ & $5 \mathrm{~S} / 0 \mathrm{~W}$ & 260 & 8.2 \\
4. & FS $\# 75-2011$ & $8 \mathrm{~S} / 0 \mathrm{~W}$ & $260-270$ & 8.9 \\
5. & FS \#26-2012 & $7 \mathrm{~S} / 1 \mathrm{~W}$ & $220-250$ & 9.2 \\
\hline
\end{tabular}




\begin{tabular}{|c|c|c|c|}
\hline 6. $\mathrm{N} / \mathrm{A}-2012$ & $7 \mathrm{~S} / 3 \mathrm{~W}$ & $210-220$ & 9.5 \\
\hline 7. FS \#28-2012 & $18 \mathrm{~S} / 0 \mathrm{~W}$ & 270 & 9.5 \\
\hline \multirow[t]{2}{*}{ 8. FS \#73-2011 } & $12 \mathrm{~S} /-1 \mathrm{~W}(1 \mathrm{E})$ & $260-270$ & 8.5 \\
\hline & Range: 8.2-9.5 & Average: 8.95 & Total: 71.6 \\
\hline \multicolumn{4}{|l|}{ GR-145 pH Test Results } \\
\hline Field Specimen \#/Year & Grid Location & Depth (cmbd) & $\mathrm{pH}$ \\
\hline 1. N/A-2012 & $3 \mathrm{~N} / 11 \mathrm{E}$ & 205 & 8.9 \\
\hline 2. FS \#75-2011 & $3 \mathrm{~N} / 11 \mathrm{E}$ & 190 & 9.5 \\
\hline 3. FS \#106-2011 & $2 \mathrm{~N} / 10.5 \mathrm{E}$ & 200 & 8.9 \\
\hline 4. FS \#72-2012 & $4 \mathrm{~N} / 12 \mathrm{E}$ & $220-230$ & 8.4 \\
\hline 5. FS \#69-2012 & $3 \mathrm{~N} / 11 \mathrm{E}$ & 230 & 9.4 \\
\hline 6. FS \#74-2012 & $2 \mathrm{~N} / 2 \mathrm{E}$ & 0 (surface) & 8.4 \\
\hline \multirow[t]{2}{*}{ 7. FS \#73-2012 } & $7 \mathrm{~N} / 13 \mathrm{E}$ & 210 & 8.4 \\
\hline & Range: 8.4-9.5 & Average: 8.84 & Total: 61.9 \\
\hline
\end{tabular}

The averaged results reveal little difference in the $\mathrm{pH}$ profiles of the two sites. Ranges are similar as well.

My second test was conducted to detect possible elevated phosphate levels at GR-2, which may indicate the presence of decayed bone or feces. According to Joseph Lambert:

"[P]hosphate forms highly insoluble compounds with iron, aluminum, and manganese, which are widely present in soils, particularly clays. These elements help to lock up the phosphate for considerable periods of time, providing a useful chemical residue of human activity that the archaeologist can exploit in searching for and understanding sites of human habitation" (1997:34).

This information is particularly relevant for GR-2, where the diminished presence of animal bone may be partly attributable to higher rates of disintegration, caused by soil chemistry or other natural processes (Banning 2000, Lambert 1997). 
I conducted my test with a common gardener's soil-test kit purchased in a retail nursery. The results are shown in Table 6:

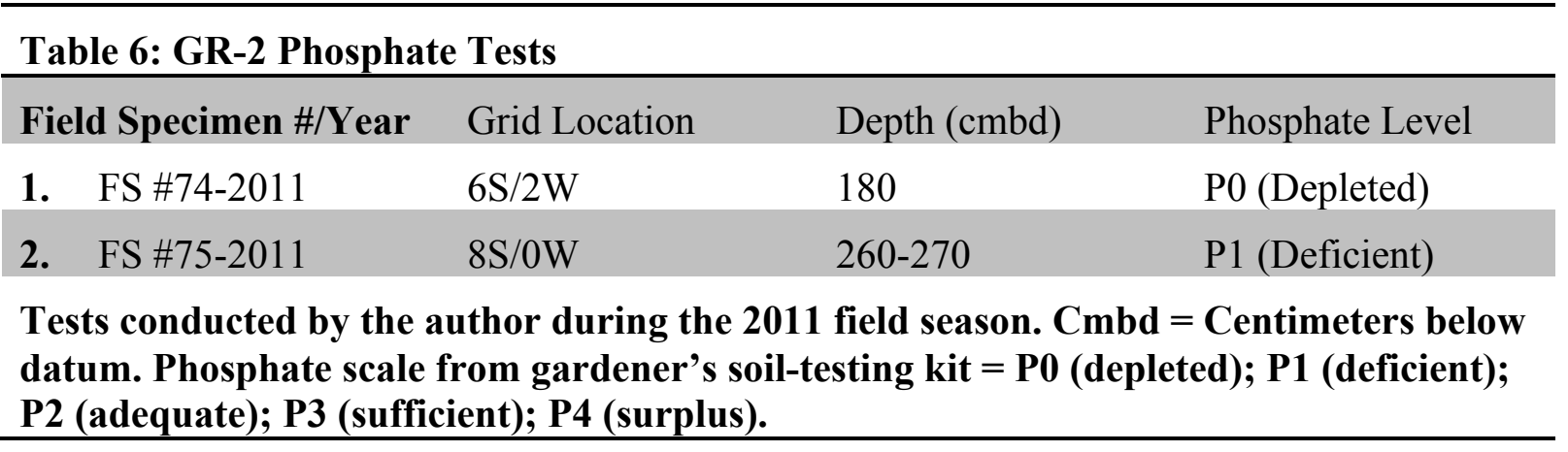

There is little or no evidence for phosphate in either of the GR-2 soil samples. Investigative methods

"We think of ourselves as social scientists first and natural scientists second. Thus, we view bones as artifacts, and our primary interest is to make them inform on the activities of past cultures."

- Brian Hesse \& Paula Wapnish (1985:v.)

One of the more frequent observations of seminar participants who work at both Ghost Ranch sites is the disparity in the number and condition of faunal remains. Remarks to this effect are made in passing, as uncontroversial instances of shared knowledge. Casual investigation of comparative remains supports this generalization. In recent years, diggers have been recording cultural-bone counts of greater than 100 for single unit-levels excavated at GR-145, while identifying only occasional fragments or slivers at GR-2 (Figure 12). Furthermore, specimens collected at GR-145 are often larger and more easily identified, suggesting differences in processing or preservation between the two sites. 


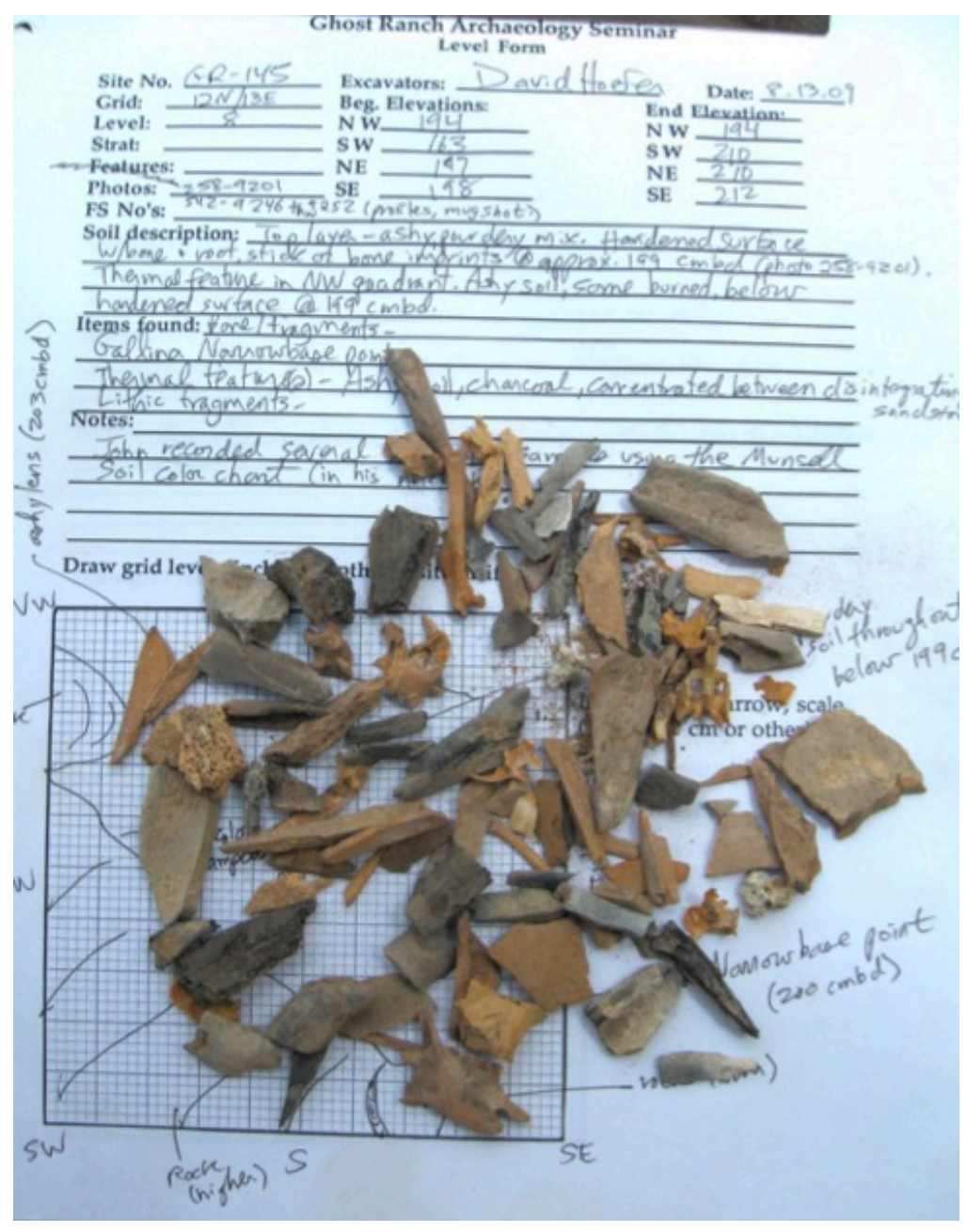

Figure 12. Excavated bone from one unit-level at GR-145. There is no equivalent instance of this at GR-2, which has been under excavation since 1990. Source: author photo.

This apparent discrepancy in bone counts creates an opportunity for archaeological inquiry. If, on further analysis, this discrepancy remains intact, why would two prehistoric campsites a mere five kilometers apart, in mostly similar ecologies, and with otherwise closely matching assemblages, diverge so completely with regard to one taxon of data? Are the reasons cultural, relating to manifestations of human agency in a world of collection economies and transitory places? Or are the reasons found in nature, in the taphonomic vehicles of soil and weather, and in the ultimate consumption of all living things by the passage of time? 
I have undertaken a two-part investigation to find an answer. The first part is an intersite comparison of the volume of bone found at GR-2 and GR-145. This comparison involves a closer inspection of the data than has occurred to date to confirm the discrepancy in assemblage size. The second part is an intrasite analysis at both locations, making allowances for the asymmetrical nature of the data. With this I hope to shed further light on the contrasting patterns of bone deposition.

Data and data sources

My interest in Ghost Ranch archaeology began in 2006, the first year I attended the seminar. I ultimately participated in seven consecutive, two-week field seasons, from 20062012, working at both GR-2 and GR-145. Ghost Ranch crews excavate in arbitrary units of 1 $\mathrm{x} 1 \mathrm{~m}$, to $10-\mathrm{cm}$ depths, in teams of two. Every volume of extracted soil is sifted in screens with one-quarter-inch mesh. As a result, the assemblages are likely biased against smallanimal remains, including mice, voles, toads, snakes, and other burrowing or denning creatures (James 1997, Watson in Clason, ed., 1975).

Curation of artifacts begins in the field, with on-site check-ins and temporary packing of lithics, potsherds, bone, charcoal, and debitage, and the recording of features such as hearths. Documentation includes counts, measurements, illustrations, and photography. Specimen numbers are assigned to each taxon from a unit-level, regardless of quantity. In other words, a unit-level producing one potsherd, two bones, six lithic fragments, and no other cultural remains would be assigned three specimen numbers.

The Ghost Ranch lab crew, under the direction of Maisie Morris, completes the curation process. The lab crew stabilizes artifacts for permanent storage, using archivalquality plastic bags, and corrects errors in labeling, identification, and measurement that 
occur during field curation (GRAB 2010). Besides fieldwork, I have volunteered in the lab, which has provided me with additional perspective on the artifacts, with better tools and conditions for analysis.

With the cooperation of Cheryl Muceus, former Director of Museums at Ghost Ranch, I have enjoyed favorable, though not unlimited, access to the faunal collections kept at the Florence Hawley Ellis Museum of Anthropology, the on-site facility for curation and public display of the ranch's archaeological projects. Below is a capsule description of the two primary assemblages:

- GR-145. I have in my temporary possession eight boxes of faunal material from GR145. The total unadjusted count on the eight manifests is over 5,000 pieces. Dig seasons 1997-2001 and 2003-2008 are represented. All this bone has been field and museum curated. Material from more recent seasons has not undergone curation at the museum and is therefore unavailable for study.

- GR-2. I do not have access to the faunal material excavated at GR-2, which remains in storage at the Florence Hawley Ellis Museum of Anthropology. In its place I have been provided with a copy of the database compiled by Richard Binggeli, which includes every artifact and feature recorded at GR-2 between 1990 and 2012, and their associated unit-levels. The database indicates a total faunal specimen count of 2,504 for GR-2. Some of this bone has yet to undergo museum curation.

\section{$\underline{\text { Analytical approach }}$}

In determining an analytical approach for the Ghost Ranch sites, it is critical to take into account inherent limitations on knowledge. Of considerable importance is the fact that archaeological excavation and sieving typically produces faunal and other samples that are 
unreflective of the actual total content of cultural material at an archaeological site (Davis 1987, O'Connor 2000, Payne in Higgs, ed., 1972). This is certainly the case at GRs 2 and 145, which are long-term educational projects that retain, untouched by trench or trowel, ample sections of their original plans.

The plans themselves likely represent only a fraction of theoretically complete "sites." GR-145 is salvage archaeology: It sits on a low-lying bench in a high-energy stream channel and is subject to frequent bouts of erosion (site report, Jul. 14, 2005). GR-2 occupies a floodplain location that, for economy's sake, was singled out for excavation among a smorgasbord of potential sites with surface scatters, hearths, petroglyphs, and other features. Put another way, GR-2 may be an artificial construct in a palimpsest environment of dozens or hundreds of temporary, overlapping habitations. At both locations, complete recovery of faunal material is impossible. ${ }^{9}$

A second issue is the size of the current assemblages, which have an adjusted combined count of nearly 8,000 pieces, with more coming on an undetermined schedule, following laboratory curation. The volume of this material makes sampling a necessary feature of analysis (Banning 2000, Drennan 1996, Fletcher \& Lock 2005).

Finally, a third concern: the divergent nature of data collection and documentation at the two sites. The GR-2 database offers a comprehensive, if superficial, overview of an entire cultural assemblage. The GR-145 faunal material creates opportunities for in-depth analysis

\footnotetext{
${ }^{9}$ The GR-145 plan is more or less contiguous with the secondary bench on which it sits. Of course, an indeterminate portion of the bench has melted away over time, as colluvial slump in the streambed. There is a case for GR-2 as a coherent site, based on a presence/absence analysis of cultural remains (Banning 2000). In 2011 and 2012, Chris Crews dropped test pits in squares to the east, west, and south of the current grid, looking for additional evidence of habitation. He found little worth recording, minus a potsherd or two. It is highly likely, however, that GR-2's cultural remains extend, to an unknown degree, beyond the present grid.
} 
of cultural bone independent from other components of the site. This is not ideal for archaeology, which generates meaning through history inferred from associations of cultural objects (Hodder 1999 \& 2006).

I have kept these limitations in mind while constructing my approach. The available data, partial but voluminous, and lacking context beyond unit-levels and associated timedepths, are best interpreted at a general scale. Individual persons and acts fall below the threshold of visibility at Ghost Ranch, which offers instead the broad contours and enduring rhythms of the hunter-gatherer lifeway. As such, the intersite component of my investigation quantifies the differential presence of bone at GR-2 and GR-145, as a means of addressing long-cycle cultural processes rather than specific instances of use or habitation. The intrasite components deal with related issues of taxonomy and taphonomy, to the extent possible under the mismatching data sets.

Intersite analysis: quantification

Quantification has been controversial among archaeologists since the late 1960s, when paleoecology, population estimates, meat yields, and subsistence strategies began to replace taxonomic lists as the primary interest of zooarchaeology (Reitz \& Wing 1999). Customary measures, including number of identified specimens (NISP), minimum number of individuals (MNI) and minimum number of elements (MNE), have endured repeated critiques of their many shortcomings (e.g., Plug \& Plug 1990), while taphonomy and site-formation studies have emphasized the role of process and context in the creation of (statistically problematic) faunal assemblages. The literature on quantification is numerous, if not always luminous. Relevant general sources include Banning (2000), Davis (1987), Grayson (1984), Lyman (1994 \& 2008), O’Connor (2000), Rackham (1994), Reitz \& Wing (1999), and 
VanPool \& Leonard (2011). Older, still-useful volumes are Brothwell (1981) and Cornwall (1974). Hesse \& Wapnish (1985) are good on the advantages of intrasite analysis; Klein and Cruz-Uribe (1984), on the case for intersite comparisons. An excellent recent addition is Beisaw (2013).

Following Grayson (1984), Lyman (2008), and VanPool \& Leonard (2011), I have selected NISP as my standard of comparison for the presence of bone at GR-2 and GR-145. For all its flaws - e.g., a tendency to misstate taxonomic abundance due to unknown rates of fragmentation - NISP remains essential to faunal quantification if, for no other reason, counting is fundamental to mathematical reasoning (Derbyshire 2006). NISP has other strengths as well: it is simple to derive, is widely recognized, and is consistent within analytical units but additive across them. Its chief competitor, MNI, does not share its scalability, being sensitive to the aggregation of analytical units that it describes. Perhaps more importantly, MNI is statistically dependent on NISP, as the lower boundary of an estimate of taxonomic abundance. Between the two, says Lyman, NISP is better suited than MNI as an indicator of ordinal-scale relationships. "NISP is to be preferred over MNI as the quantitative unit used to measure taxonomic abundances," he writes (2008:81).

NISP's utility in ranking the Ghost Ranch sites is critical to my analysis because I have bone counts for both locations but no means of determining MNIs for the GR-2 material. In my time at Ghost Ranch, I found that seminar participants were skillful in identifying bone in the generic sense, without being able to add much in the way of taxonomic information (which would be necessary to compute MNIs). This held true in the lab as well as in the field. 
Intrasite analysis: quantification and identification

Intrasite analysis focuses on the GR-145 faunal material. I selected about one-third of the on-hand specimens for evaluation (roughly 1,900 pieces), typically from the older seasons and upper units of the site, where there is a greater likelihood of chronological overlap with the faunal material at GR-2. Besides comparing NISP counts, I explore two additional measures of archaeological significance:

- NISP:MNE ratio. Like MNI, MNE is statistically related to NISP. Nevertheless, the NISP:MNE ratio is a valuable measure of fragmentation for particular (long bone) elements. However, Lyman does not view MNE favorably as a quantitative unit, sharing as it does many of the same weaknesses as MNI. ${ }^{10}$

- Ubiquity. With ubiquity, I can provide a presence/absence analysis that is independent of the flawed measures of taxonomic abundance. It serves as a general indicator of concentration or diffusion within a sample, and, as a measure of siteformation processes, is good at ferreting out the tendency of cultural remains to be grouped together on a site, rather than randomly dispersed among the units (Banning 2000).

Another stage of my intrasite analysis involves taxonomy, or the categorization of data by naming. Taxonomy stages data for further analysis (Hesse \& Wapnish 1985, Payne in Higgs, ed., 1972, Reitz \& Wing 1999). There are two broad categories involved: Linnean and anatomical. Linnean identification reflects the degree of diagnostic detail in each specimen, whether at the level of species, genus, family, or order. Anatomical identification names whole bones from complete or fragmented samples, plus long-bone elements: proximal end,

\footnotetext{
${ }^{10}$ In fact, MNI is a special case of MNE, in which all elements are present in a unified whole and fragmentation equals zero (Lyman 2008).
} 
shaft, and distal end. In some instances, I record age and side (left vs right) data, in addition to visual observations such as cut marks, burns, or preservation status. I use a coding system that I developed for recording Linnean, anatomical, and other forms of data in spreadsheets.

Taxonomic precision and accuracy is made possible by reference to comparison collections and high-quality illustrations. I relied, to some extent, on the faunal collections in the University of Louisville Archaeology Lab, as well as numerous reference works including Olsen on North American species anatomy (1964, 1968, 1978 [with R. Wheeler] \& 1979), Hillson on dentition (1992 \& 2005), Gilbert on mammalian osteology (1990), and Elbroch on skulls and cranial elements (2006). I also referenced works on species biology, with a focus on the zoology of New Mexico (for example, Degenhardt, et al, 1996, Findley 1987, Hall 1981, Koster 1957, Miller, Jr., \& Kellogg 1955, Rostlund 1952, Wheeler \& Jones 1989, and Williams 2000).

Where possible given its lack of detail, I also use the GR-2 database for intrasite analysis. Investigation centers on questions of ubiquity, with the added interest of associational links between faunal and other cultural remains.

$\underline{\text { Intersite comparison }}$

The intersite analysis of GR-2 and GR-145 focuses on the comparative presence of animal bone, as measured by NISP. In all cases, NISP refers to bone excavated in archaeological contexts. ${ }^{11}$ The value of this comparison, which can be stated as a ratio, lies in the glimpse that it provides of possibly divergent uses for these locations by prehistoric

\footnotetext{
${ }^{11}$ This assumption removes the difference between human-transported and naturally occurring faunal deposits (usually small mammals). My concern, however, is to characterize cultural space rather than to stockpile cultural acts.
} 
humans. Other explanations are possible, of course, and will be considered in the next section.

The GR-2 database and the GR-145 inventory include raw NISP data. The resultant 2.00:1 ratio for the GR-145/GR-2 specimen counts was surprisingly low, given the frequent assessment by seminar participants that one location was bone bountiful while the other was bone bereft. One factor skewing the counts was clerical errors in the GR-145 manifests, which tended to underrepresent the actual number of specimens. Nevertheless, corrected counts altered the ratio only slightly (Table 7). ${ }^{12}$

\section{Table 7: Comparative Bone Counts at GR-2 and GR-145}

\begin{tabular}{lcccc}
\hline Site & $\begin{array}{l}\text { Unadjusted NISP } \\
\text { GR-145 }\end{array}$ & $\begin{array}{c}\text { Unadjusted Ratio } \\
\text { (GR-145:GR-2) }\end{array}$ & Adjusted NISP & $\begin{array}{c}\text { Adjusted Ratio } \\
\text { (GR-145:GR-2) }\end{array}$ \\
\hline GR-2 & 5,002 & $2.00: 1$ & 5,467 & $2.18: 1$ \\
\hline & 2,504 & 2,504 & \\
NISP refers to the number of bone specimens in an archaeological context. Adjusted \\
NISP incorporates corrections to clerical errors, as recorded on the site inventory.
\end{tabular}

There was, however, a second and more significant factor at work. As previously noted, the radiocarbon dates determined from fireplace charcoal at both sites show human habitation of GR-2 to be of greater time-depth than GR-145. To eliminate time as a wasting variable in comparing bone volumes at the two sites, it was necessary to determine which portion of the GR-2 faunal assemblage was attributable to the period when both sites were in use, by the same or different groups of people. In other words, for my comparison to be consistent, I had to identify the overlapping time segments of the two soil columns.

\footnotetext{
${ }^{12}$ The gain in counts was somewhat offset by the apparent fragmentation of some specimens during shipping, falsely inflating NISP.
} 
$\underline{\text { GR-145 dates }}$

GR-145 crew chief, John Hayden, began collecting fireplace charcoal during the 1996 archaeological seminar. Early evidence suggested at least three periods of high use for the site, associated with activity levels and thermal features: A.D. 700-1025, A.D. 1290-1345, and A.D. 1435-1660 (site report, Jul. 14, 2005). In recent years, I pressed the site's diggers to go deeper for (presumably) older datable material. Table 8 displays the results of the four most recent analyses. Specimen 145 from the 2012 season, at $2150 \pm 30$ BP ( $\approx 200$ B.C.), is the oldest date produced by GR-145, at its lowest extremity:

Table 8: Recent GR-145 Radiocarbon Dates

\begin{tabular}{lllll}
\hline Specimen \# & Year Collected & Grid Location & Depth $(\mathrm{cmbd})$ & Date Range \\
$\mathbf{1 7 8}$ & 2009 & 12N/13E & 195 & $1720 \pm 30 \mathrm{BP}$ \\
$\mathbf{2 8 2}$ & 2009 & $6 \mathrm{~N} / 7 \mathrm{E}$ & $160-170$ & $1550 \pm 30 \mathrm{BP}$ \\
$\mathbf{1 6 3}$ & 2010 & $9 \mathrm{~N} / 13 \mathrm{E}$ & 210 & $1670 \pm 30 \mathrm{BP}$ \\
$\mathbf{1 4 5}$ & 2012 & $2 \mathrm{~N} / 10 \mathrm{E}$ & 289 & $2150 \pm 30 \mathrm{BP}$
\end{tabular}

Dates reported in radiocarbon years before present, where present $=$ A.D. 1950. Source: Beta Analytic, Inc., report (Oct. 1, 2012).

\section{$\underline{\text { GR-2 dates }}$}

GR-2 crews have utilized several absolute-dating methods from early in the site's excavation history, including radiocarbon, tree-ring, obsidian-hydration, and one example of human writing (the April-1916 date in Nikolas Lovato's cliff-face graffito). Because of the large number of hearths discovered at GR-2, radiocarbon dating has been emphasized. By 2007, site crews had collected 174 charcoal samples, 43 of which had been dated in professional laboratories using a calibrated-radiocarbon method (GRAB 2008). More has been collected since then. GR-2 has generated a broad sweep of dates, especially rich in the 
Oshara Archaic (5500 B.C.-A.D. 400). The oldest date remains late-Paleo 8065 BP ( $\approx 6115$

B.C.), suggesting on-and-off human use of GR-2 for more than eight millennia.

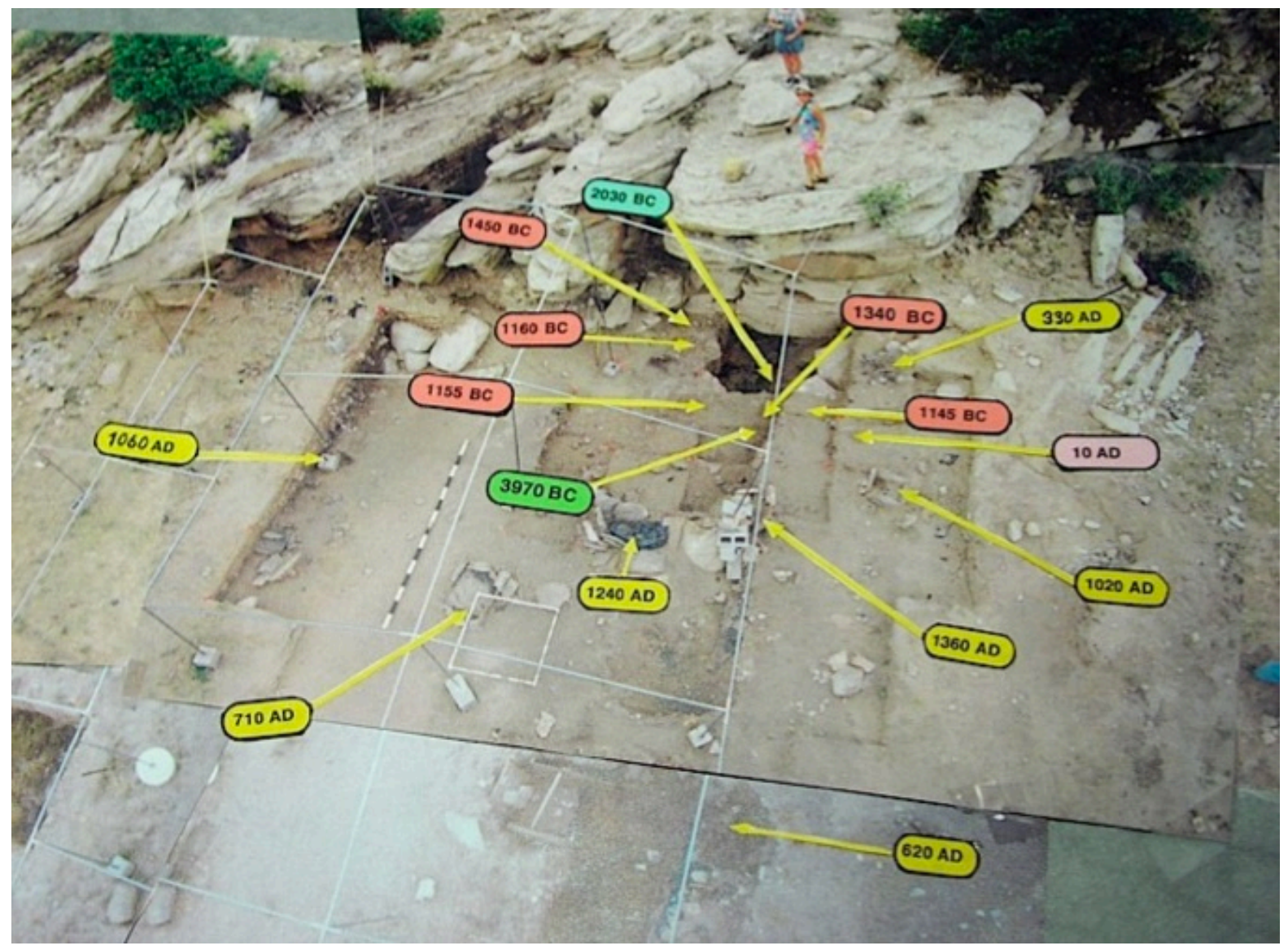

Figure 13. GR-2 has produced a wide range of absolute, mostly radiocarbon dates, starting from late Paleo all the way to the $20^{\text {th }}$ century A.D. Source: Richard Binggeli photo.

Figure 14 provides a visual summary of the chronometric relationship of GR-2 and GR-145, based on a partial listing of radiocarbon dates. Overlap occurs late in the Archaic (En Medio phase), and continues intermittently through the Formative and Historic eras, as viewed through the traditional Pecos chronology, rather than the Northern Rio Grande variant (A.D. 600-present): 


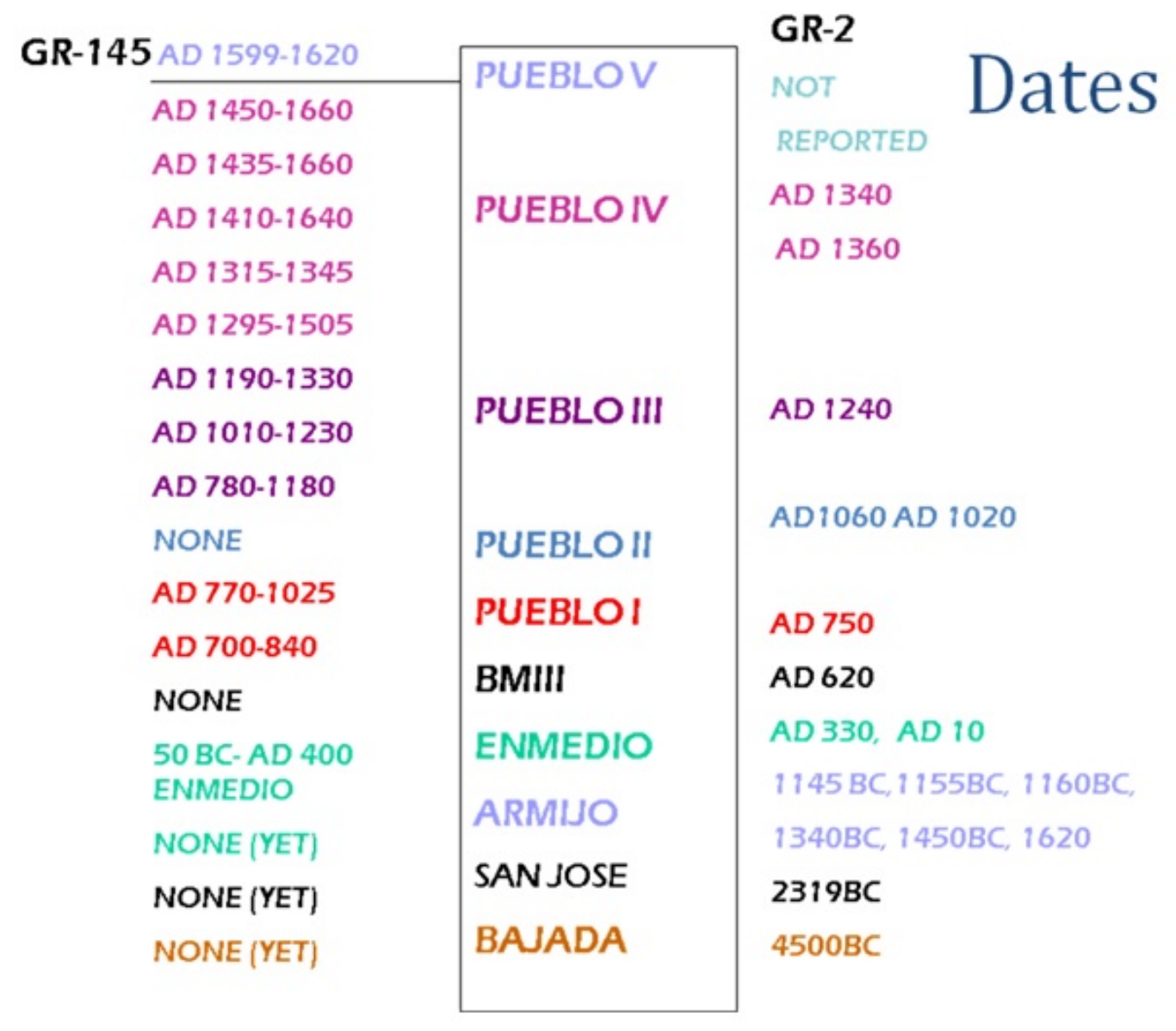

Figure 14. A partial list of comparative radiocarbon dates, correlated with standard culturehistoric periods of the northern Southwest. Source: John Hayden graphic.

The oldest available date at GR-145, from the deepest point on the site, is 200 B.C. For comparison's sake, I assume that the entire current faunal assemblage, with an adjusted NISP of 5,467, was deposited at various times between that date and A.D. 1950. (This seems reasonable, considering the fact that many of the excavated bones are associated with hearth features dated by radiocarbon to more recent time periods.) What portion of the GR-2 assemblage can be assigned to a similar time period (between 200 B.C and A.D. 1950)? 


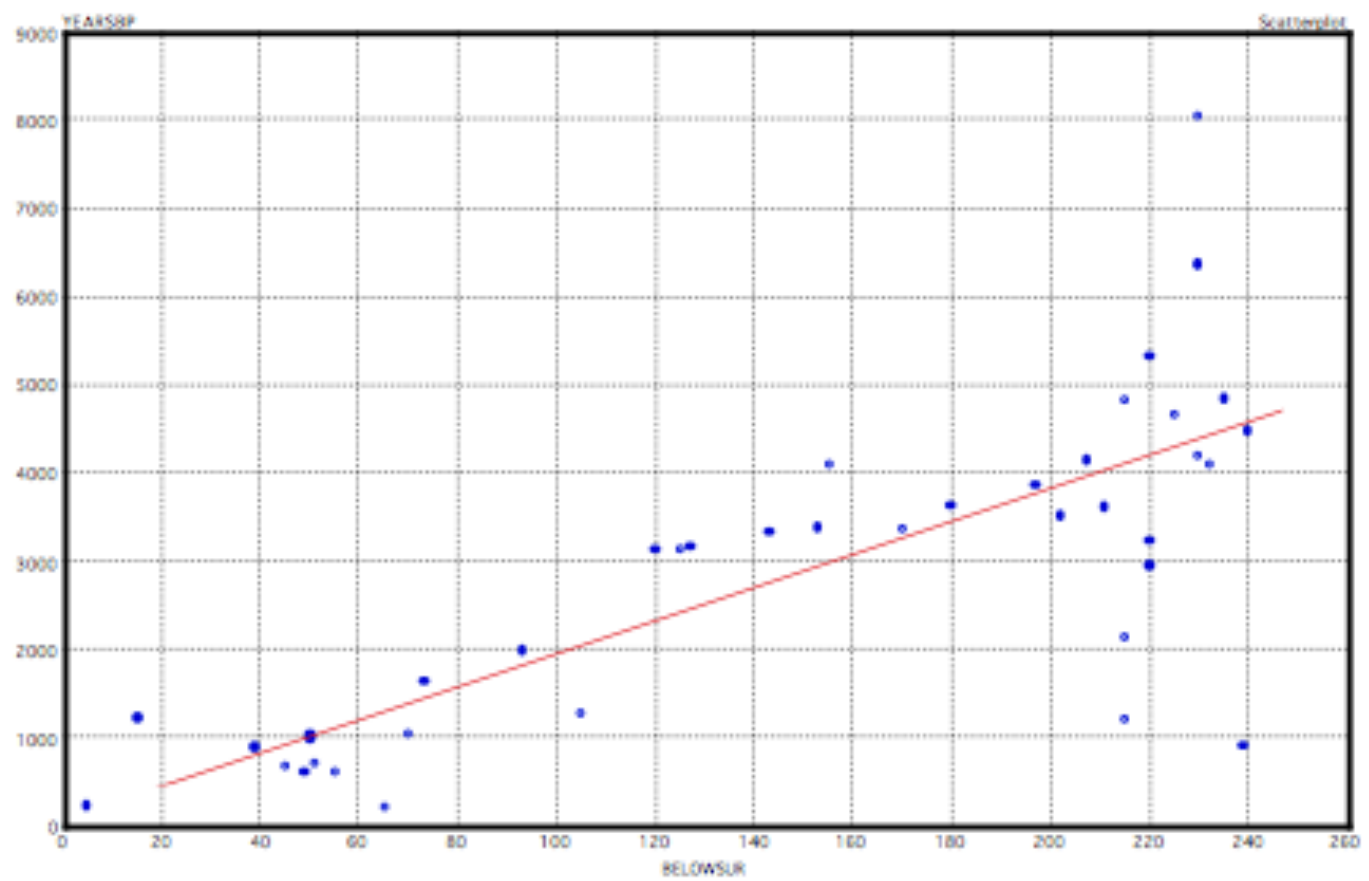

Figure 15. Scatterplot distribution of radiocarbon dates by depth below surface

(BELOWSUR) at GR-2 versus the age of the samples in years before present (YEARSBP).

The red line shows the mathematical relationship between the two factors. The correlation

coefficient is a strongly positive 0.7685. Source: Richard Binggeli graphic (in GRAB 2008).

An intriguing linear function first noted by GR-2 crew chief, Richard Binggeli,

provides an answer (Figure 15). When graphing the distribution of radiocarbon dates against

their depth of excavation, Binggeli discovered that the relationship between the two is

described in a surprisingly straightforward manner:

"A regression analysis of the depth and age factors shows that the two are highly correlated over time, despite some exceptional outliers. The analysis also suggests that their relationship is linear, with every vertical meter of soil corresponding to a period of roughly two thousand years. In other words, when excavators remove ten centimeters of soil from a ten-by-ten square - the standard unit of digging - they go back in time 200 years...GR-2's depth-age function also indicates that the site was in relatively continuous use by Archaic-Indian groups for thousands of years. At least one sample from 2007, dated to 8065 BP, reaches back to the Paleo-Archaic boundary. Furthermore, these long periods of on-again, off-again occupancy saw consistent rates for the deposition and burial of human cultural remains" (GRAB 2008). 
The outliers noted above occur largely at the depths of $220-240 \mathrm{cmbd}$. The most plausible explanation for these is bioturbation, which is more prominent at GR-2 than at GR145 (Muceus, pers. comm.). In the early years of excavation, crews laid down tarps at season end, to protect the site from weathering and infill until the following summer. In subsequent years, crews would find bits of tarp in newly opened levels, transported there by burrowing animals. A likely candidate is the pocket gopher (Thomomys spp.), which has been observed on site, and which builds a complex web of underground tunnels and chambers, to a depth of about two meters (Findley 1987). Regardless, it is apparent that animal denning has had relatively little impact on the time-depth correlation at GR-2.

A similar finding for ceramic remains bolsters the case for the existence of a timedepth relationship at GR-2. Archaeological consensus sees the introduction of pottery in the Northern Rio Grande occurring around A.D. 400 (e.g., Irwin-Williams in Ortiz, ed., 1979). By the method outline above, GR-2's ceramic horizon sits at $\approx 80 \mathrm{cmbd}$ throughout the site. A data sort reveals that, in fact, more than 90 percent of all recorded sherds - 444 out of 490 specimens - have been excavated from the eight topmost unit-levels of GR-2. ${ }^{13}$ Comparative counts in the overlap

With this information, we can determine what portion of the GR-2 faunal assemblage occurred in the overlapping time period with GR-145, from 200 B.C. to A.D. 1950, or 2,150 years. If we divide 2,150 by 200 years/unit-level - the age-depth linear function at GR-2 we get 10.75 unit-levels, which I am rounding to 11 . This means that the first 11 unit-levels

\footnotetext{
${ }^{13}$ Additional support for the integrity of GR-2's site-formation process - that is, a high proportion of primary context - is provided by ceramic typologies spanning the late prehistoric and early historic eras, according to ceramicist, Heyward Franklin. Also, for what it's worth, obsidian-hydration dates, obtained during that method's brief heyday, support this reading as well (Binggeli, et al, n.d.:44).
} 
excavated at GR-2 - that is, the uppermost $110 \mathrm{~cm}(1.10 \mathrm{~m})$ of matrix from anywhere on the site - covers roughly the same time period as the entire sequence excavated to date at GR145. It is the GR-2 faunal specimens recovered from this portion of the soil column that should be compared to the corresponding bone count at GR-145.

A sort operation linking faunal remains in the GR-2 database to excavated depths $\leq$ $110 \mathrm{~cm}$ generates a revised NISP of 1,085 . The modified GR-145/GR-2 NISP ratio is 5,467:1,085, or 5.04:1. Put differently, for every unit of cultural bone excavated at GR-2 in the overlapping time segment, five-plus units have been excavated at GR-145. This is a significant disparity in bone counts, considering the many similarities of the two sites. Furthermore, the ratio is understated, because the GR-2 database is a comprehensive record of all GR-2 artifacts through 2012, whereas the GR-145 count is missing several seasons due to a backlog of work in museum curation. ${ }^{14}$

Intrasite analysis: GR-145

The intuitive understanding of seminar participants, that GR-145 boasts rich faunal remains compared to GR-2, is validated by the intersite assessment of bone counts. The next step in analysis is to look for additional on-site support of the main conclusion, as well as reinforcing the cultural nature of both locations. As we shall see, the sister sites of Ghost Ranch show evidence of differentiated subsistence behaviors by late-prehistoric foragers on the verge of agriculture - a time when annual spaces were becoming permanent places.

\footnotetext{
${ }^{14}$ This analysis has another implication: the accelerated rate of site formation at GR-145, when compared to GR-2 (2.89 m vs. $1.10 \mathrm{~m}$ at 2,150 years, assuming GR-145's oldest radiocarbon date is in primary context). If true, this may be explained by the primary sources of sedimentation at GR-145, overbank flooding and colluvial runoff, as amplified by the site's location within the stream channel (Leopold 1994).
} 
As previously noted, GR-145 data is largely based on in-hand faunal material. I

analyzed 1,910 pieces of bone out of the total, drawn from boxes 4,5 , and 8 . These samples cover the dig seasons of 1997, 1998, 1999, and 2005, are mostly high in the soil column, and are therefore more likely to overlap chronologically with upper-level material from GR-2, allowing for the possibility of post-depositional disturbance and artifact movement within the soil column at GR-145.

\section{Ubiquity}

Ubiquity indicates presence/absence of data within sampled spaces, which is potentially useful for interpreting that data. The human tendency to organize space as a resource means that, in stable media, artifacts, including cultural bone, tend to remain densely located, rather than dispersing more widely from activity centers - hearths, butchery sites, and so on (Banning 2000). ${ }^{15}$ This variation in density appears to hold true for bone at GR-145, when comparing concentrations within the 77 unit-levels of Box 4 material $(\mathrm{NISP}=485)$ :

\section{Table 9: Distribution of Bones within the Matrix (GR-145, Box 4 Only)}

\begin{tabular}{|lcc|}
\hline Assemblage Totals & $\begin{array}{c}\text { Specimens Per Unit- } \\
\text { level }\end{array}$ & $\%$ of Total NISP \\
\hline $\mathbf{3 1}$ unit-levels: 409 NISP & 13.19 & 84.33 \\
\hline $\mathbf{4 6}$ unit-levels: $\mathbf{7 6}$ NISP & 1.65 & 15.67 \\
\hline $\begin{array}{l}\text { Unit-level }=\mathbf{1} \mathbf{m} \times \mathbf{1} \mathbf{m} \mathbf{x} \mathbf{1 0} \mathrm{cm} \text {. Unit-levels sorted into groups with bone counts } \geq \mathbf{5} \text { vs. } \\
\text { those with bone counts }<\mathbf{5} \text {. No individual specimens or unit-levels are counted more } \\
\text { than once. }\end{array}$ \\
\hline
\end{tabular}

\footnotetext{
${ }^{15}$ GR-145 likely saw the rapid burial of bone and other cultural materials, based on the primary sources of sedimentation, cliff runoff, and streambed flooding. Buried remains, insulated from the caprices of weather, are exposed to subtler forms of taphonomic disintegration than surficial deposits (Ashmore \& Sharer 2014, Lyman 1994).
} 
About 40 percent of the sampled unit-levels contain nearly 85 percent of the total NISP. At a minimum, this type of non-random result suggests a relatively stable depositional environment. This stability is further supported by a second means of measuring ubiquity, involving unit-level fractions rather than unit-levels per se:

\section{Table 10: Distribution of Bones within the Matrix (GR-145, All Boxes)}

\begin{tabular}{|lcc|}
\hline Assemblage Totals & $\begin{array}{c}\text { Specimens Per Unit- } \\
\text { level Fraction }\end{array}$ & \% of Total NISP \\
\hline $\mathbf{3 7}$ unit-level fractions: 913 NISP & 24.67 & 47.80 \\
\hline $\mathbf{2 0 1}$ unit-level fractions: 997 NISP & 4.96 & 52.20 \\
\hline $\begin{array}{l}\text { Unit-levels sorted into groups ("fractions") with bone counts by common element } \geq \mathbf{5} \text { vs. } \\
\text { those fractions with bone counts } \\
\text { counted more than once. }\end{array}$ & . No individual specimens or unit-level fractions are \\
\hline
\end{tabular}

Unit-level fractions consist of common Linnean-anatomical elements within a unitlevel. In Table 10, about 16 percent of all unit-level fractions contain almost half of the sampled NISP, dominated by Artiodactyla remains. I developed this measure in response to the prevalence of long-bone shards and splinters in the Box 4 ubiquity analysis. The colocation of what appears to be shattered long-bone remains, regardless of unit-level, points to the creation of cultural spaces by humans, organized for animal processing and consumption (Cornwall 1974, Hesse \& Wapnish 1985). ${ }^{16}$

\footnotetext{
${ }^{16}$ Unit-level fractions arguably discern spatial autocorrelations rather than mere cluster effects, in which the analyzed samples are dependent on some characteristic of the physical location (e.g., the butchery discard pattern at a hunting site) (Banning 2000). If not spatial then cultural autocorrelation?
} 


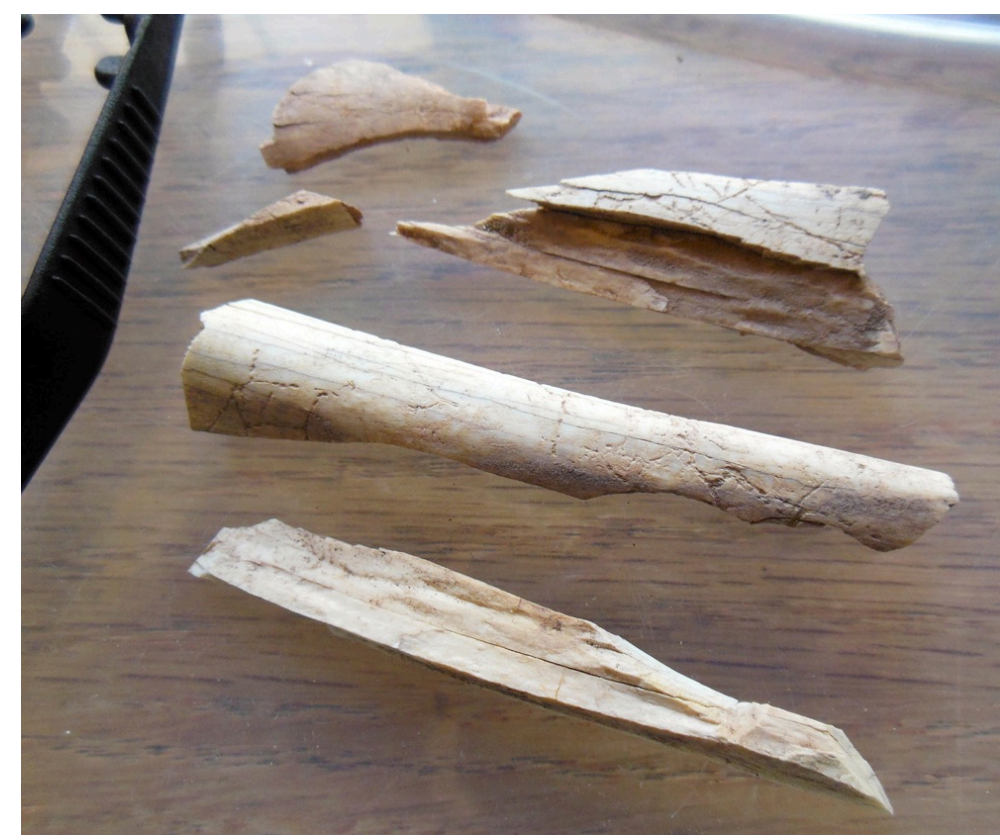

Figure 16. Long-bone fragments from GR-145. Source: author photo.

Human-modified Bone

Though suggestive, mere concentrations of animal bone do not prove human intervention or involvement. Natural animal deaths and predatory consumption occur on sites occupied only intermittently by humans, and can bleed into the cultural record, thanks to siteformation and related processes (Davis 1987, O’Connor 2000, Reitz \& Wing 1999). The case for human authorship of faunal transformation is strengthened by evidence of certain acts visited by persons on the bones themselves, including cutting, burning, and modification for future use:

\section{Table 11: Human-modified Bone (GR-145)}

Type of Modification

NISP

Bones with cut-marks or evident disarticulation

Bones with evidence of burning 805

Human-shaped bone, possibly tools

Total: $832 *$

* Represents $43.56 \%$ of total NISP sample. No bone is counted more than once. 
At GR-145, 43.56 percent of the sample, or three bones in seven, show evidence of human-caused change. Most common is burning, in 805 blackened or calcined pieces.

Cooking seems a more likely explanation than natural or human-started wildfires, because of the mix within unit-levels of burned and unburned bone. Direct-contact roasting may have been employed (Stiner, et al, 1995). Stone-tool incisions or wrenching damage appears on 25 pieces, though that number may underrepresent the actual level of cutting and twisting, due to the degree with which burning obscures surface detail. ${ }^{17}$ Only two examples of humanshaped bone are recorded, possibly picks or awls. Portability is characteristic of collectioneconomy tools; it is possible that GR-145's inhabitants produced additional pieces on site that were discarded at other locations in a far-flung operational sequence (Ingold 2000). Faunal identification

I analyzed every bone in the GR-145 sample for anatomical and Linnean identity. Many of the bones were fragmentary remains offering little in the way of diagnostic landmarks ("indets" - 29 percent overall). I categorized a second group, which provided osteological information but no apparent Linnean form, by size, based on length or thickness of bone, as tiny/small/medium/large (e.g., vole/squirrel/rabbit/deer for mammals, with a related progression for birds). 597 specimens linked to some level of Linnean identity - 31 percent of the sample. Table 12 lists these specimens by taxa:

\footnotetext{
${ }^{17}$ Also evident is root etching, small-mammal tooth marks, and a very few carnivore dental punctures.
} 


\section{Table 12: Animal Bone by Linnean Taxa (GR-145)}

Taxa

Total NISP

$\%$ of Total

LEP/Leporidae

28

4.68

M021/cf. M021: "Lepus"

2

0.34

M022/M022.3/cf. M022.3: "Sylvilagus"

49

Total Lagomorpha: NISP=79 (13.23\% of assemblage)

Rodentia

39

6.52

ARV/Arvicolidae

2

0.34

SCU/Sciuridae

3

0.50

Heteromyidae

13

2.18

M023: "Sciuris"

0.17

M033: "Dipodomys"

0.17

M046.2: "Montane vole (M. montanus)"

2

0.34

Total Rodentia: NISP=61 (10.22\% of assemblage)

Cf. M065: "Bobcat (L. rufus)" 1

Total Carnivora: NISP $=1$ ( $0.17 \%$ of assemblage)

Artiodactyla

BOV: domestic goat or sheep (post-Entrada)

0.17

CER/Cervidae

M067.1: "White-tailed deer (O. virginianus)"

M067.2: "Mule deer (O. hemionus)"

38

6.37

M069.1: "Pronghorn antelope (A. americana)"

2

0.34

M070.1: "Bighorn sheep (O. canadensis)"

8

Total Artiodactyla: NISP=365 (61.14\% of assemblage)

Aves/cf. Aves

88

14.73

Cf. Passeriformes: "Songbirds"

1

0.17

B057.1: "Wild Turkey (M. gallopavo)"

2

0.34

Total Aves: NISP=91 (15.24\% of assemblage)

Totals:

597

100.00

Taxonomic codes are based on a system I developed for my thesis. Rounding errors possible. 
Identifiable specimens fall primarily into four broad taxa: Artiodactyla, Aves, Lagomorpha, and Rodentia. The first three are traditional hunting categories, as reflected in the standard faunal indices used by Southwestern archaeologists today (Driver in Varien \& Wilshusen, eds., 2002). GR-145's NISP percentage by hunt taxon is shown below:

Percent of Total NISP, Major Hunt Taxa

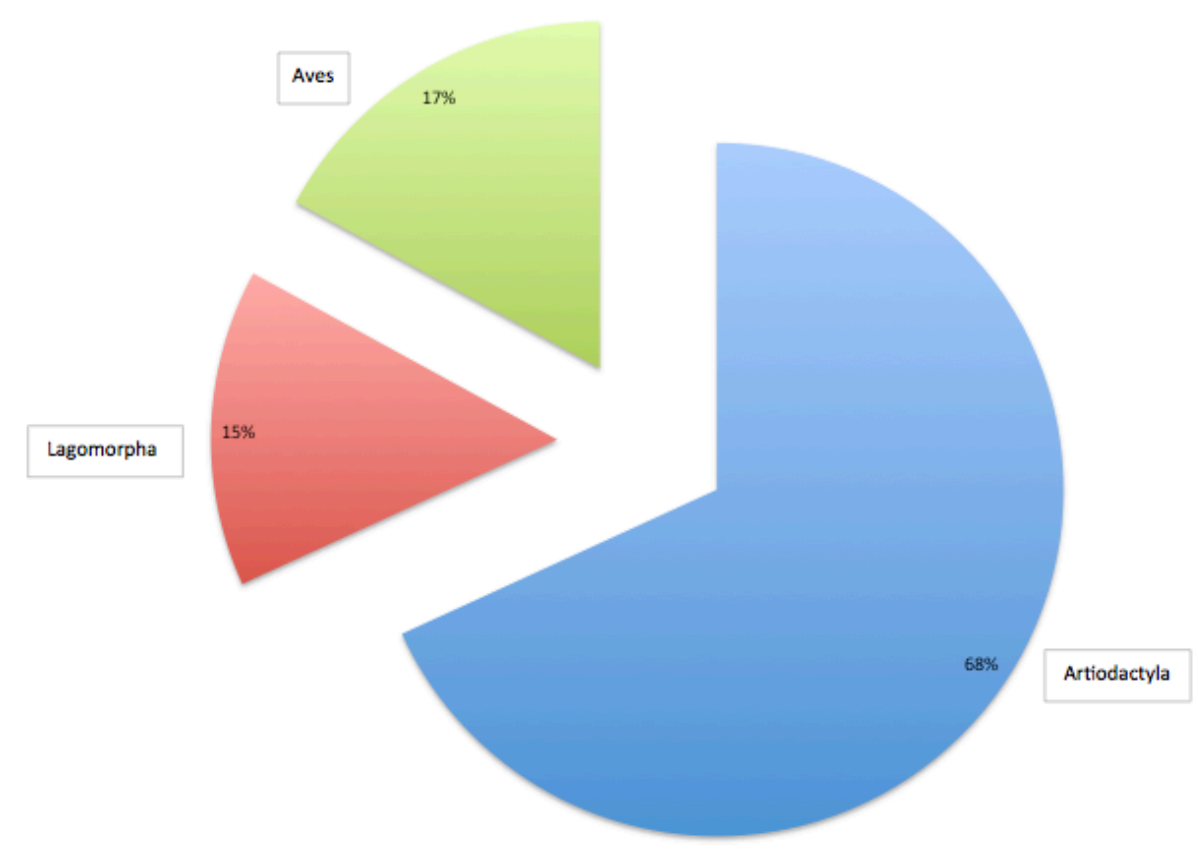

Figure 17: Artiodactyla specimens, especially mule deer (O. hemionus), dominate the GR145 faunal assemblage. There is also on-site evidence for rabbit (likely the desert cottontail, Sylvilagus audubonii) and a variety of birds, including Wild Turkey (Meleagris gallopavo). Source: GR-145 faunal data.

Element identification

Tables 13 and 14 display element counts from two Linnean categories, Artiodactyla and mule deer (O. hemionus). Dental and long bone fragments largely define the Artiodactyla count: 


\section{Table 13: Artiodactyl Elements by Count (GR-145)}

\begin{tabular}{|lr|}
\hline \multicolumn{1}{c}{ Element } & Count \\
\hline Calcaneus & 1 \\
\hline Femur & 2 \\
\hline Humerus & 1 \\
\hline Innominate & 2 \\
\hline "Long bone" & 224 \\
\hline Metatarsus & 2 \\
\hline Phalanx & 3 \\
\hline Rib & 2 \\
\hline Scapula & 3 \\
\hline Tibia & 2 \\
\hline Tooth & Total: \\
\hline Ulna & 53 \\
\hline & 296 \\
\hline
\end{tabular}

Though smaller in number, the mule deer sample contains more identified elements (15 to 12), pointing at a correlation between greater anatomical detail and Linnean precision:

\section{Table 14: Mule Deer Elements by Count (GR-145)}

\begin{tabular}{|lr|}
\hline \multicolumn{1}{|c}{ Element } & Count \\
\hline Axis & 1 \\
\hline Cf. humerus & 1 \\
\hline Calcaneus & 1 \\
\hline Cranium & 1 \\
\hline Cervical vertebra & 1 \\
\hline "Long bone” & 3 \\
\hline Mandible & 5 \\
\hline Metatarsus & 2 \\
\hline Phalanx & 2 \\
\hline Radius & 3 \\
\hline
\end{tabular}




\begin{tabular}{|c|c|}
\hline Radius-ulna & 1 \\
\hline Talus & 2 \\
\hline Tibia & 2 \\
\hline Tooth & 11 \\
\hline Ulna & 2 \\
\hline & 38 \\
\hline
\end{tabular}

The Artiodactyl assemblage appears highly processed, suggesting human involvement, but might also result from differential perseveration. The mule-deer assemblage hints at whole-carcass processing for meat, marrow, and grease - an interpretation that is consistent with the presence of GR-145's butchery anvil. Most deer parts have nutritional utility and at least some of the ethnographic literature records whole-animal transport and/or processing of deer, wapiti, and pronghorn, especially among hunting parties (Beaglehole \& Sapir 1936, Buskirk 1986, Heffelfinger 2006). But transport and butchery practices diverge widely according to culture and circumstance, so the taphonomic implications of the identified elements remain uncertain (Reitz \& Wing 1999).

Degree of fragmentation

Ubiquity analysis, human-modified bone, and a high incidence of game taxa all support the interpretation of GR-145 as an intermittently occupied hunting camp. A fourth line of evidence is the high degree of fragmentation evident in long-bone remains. Whole bones constitute less than three percent of the analyzed sample. Epiphyseal ends are poorly represented. Broken shaft fragments dominate the long-bone assemblage, as more than 80 percent of aggregate NISP (shaft-only count $=652$ ): 


\section{Table 15: Long-bone Elements as Fragmentation Measure (GR-145)}

$\begin{array}{lccc}\text { Total long-bone } & \text { Part or Whole Bone } & \% \text { of Total Count } & \text { Long-bone Elements } \\ \text { NISP } & \text { Present } & \text { Represented } & \text { Present (P, S, or D) }\end{array}$

\begin{tabular}{|c|c|c|c|}
\hline 812 & Part $=791$ & 97.41 & $\mathrm{P}=29$ \\
\hline & & & $\mathrm{S}=652$ \\
\hline & & & $\mathrm{D}=19$ \\
\hline & & & $\mathrm{PS}=51$ \\
\hline & & & $\mathrm{SD}=40$ \\
\hline & Whole $=21$ & 2.59 & $\mathrm{PSD}=21$ \\
\hline
\end{tabular}

Mammalian and avian long bones: femur, humerus, radius, radius-ulna, tibia, tibiafibula, tibiotarsus, ulna, and "long bone." Long-bone elements: $P=$ proximal end, $S=$ shaft, $D=$ distal end. No element-configuration is counted more than once.

Though some Southwestern predators with a powerful maxillofacial apparatus - the mountain lion ( $P$. concolor), for instance - prey on mule deer and similar species, the scarcity of puncture wounds within the sample is telling. The presence of hearths, projectile points, hammerstones, and a butchery anvil in close association with GR-145's fragmented remains underscores the role played by humans in the creation of the faunal assemblage (Figure 18). 


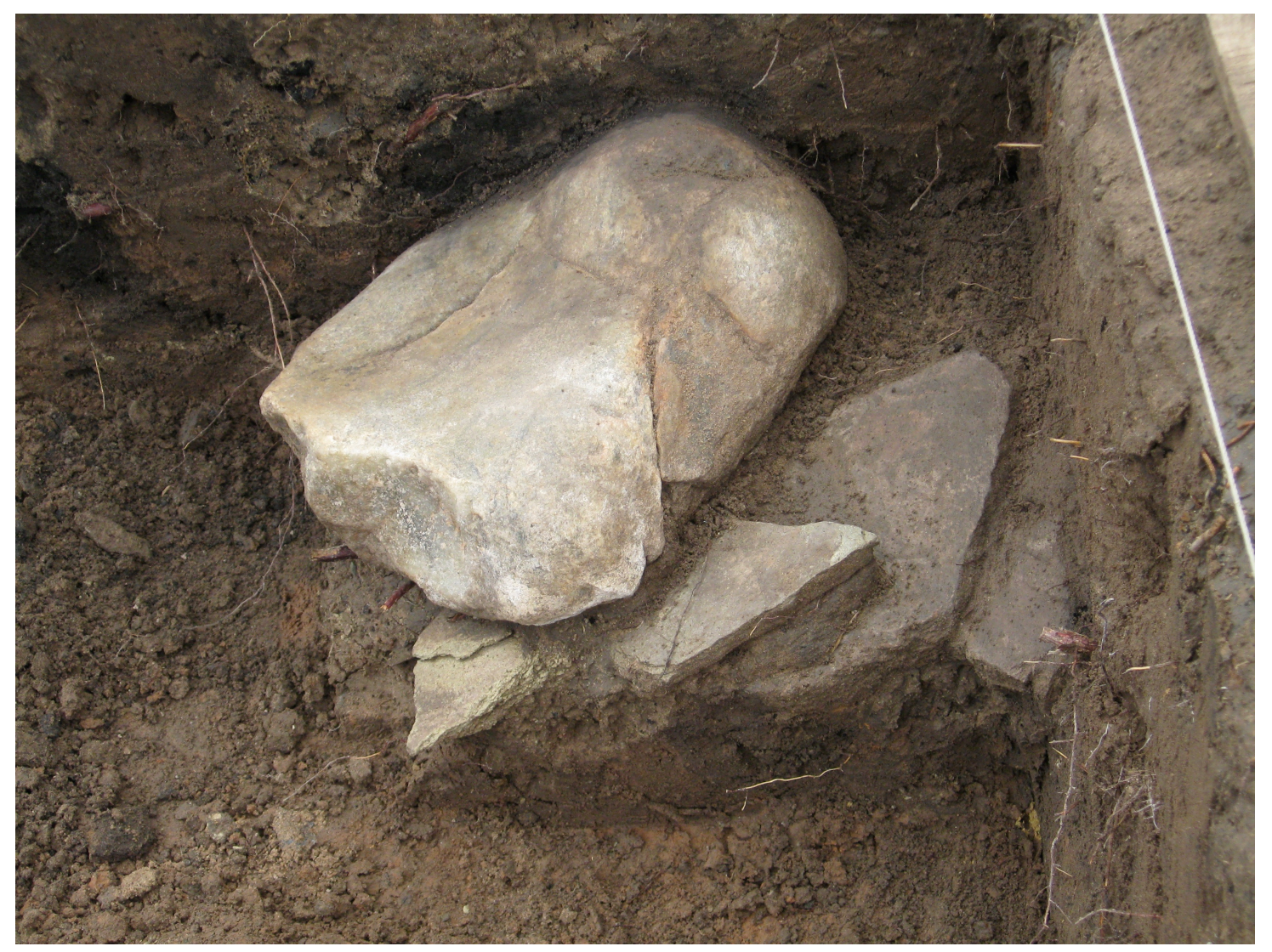

Figure 18. A butchery anvil unearthed by excavators during the 2009 dig season at GR-145. Evidence suggests that it was used for marrow extraction, grease rendering, and possible tool manufacture. Source: author photo.

$\underline{\text { Intrasite analysis: GR-2 }}$

Intrasite analysis of GR-2 is limited by the quality of the database and the low bone count of 1,085 in the chronological overlap with GR-145. Despite this, it is possible to root out some evidence of clustering, which might at least suggest a degree of human involvement with the animal remains on site. Ubiquity data is presented in Table 16 below. As with GR145 , the faunal assemblage is concentrated in a relatively small number of unit-levels (62 out of 321 , roughly 19 percent): 


\section{Table 16: Distribution of Bones within the Matrix (GR-2)}

\begin{tabular}{|lrc|}
\hline Assemblage Totals & Specimens Per Unit-level & \% of Total NISP \\
\hline 62 unit-levels: 661 NISP & 10.66 & 60.92 \\
\hline 259 unit-levels: 424 NISP & 1.64 & 39.08 \\
\hline
\end{tabular}

Unit-level $=1 \mathrm{~m} \times 1 \mathrm{~m} \times 10 \mathrm{~cm}$. Unit-levels sorted into groups with bone counts $\geq 5 \mathrm{vs}$. those with bone counts $<5$. No individual specimens or unit-levels are counted more than once.

The specimens per unit-level at GR-145 track those at GR-2 on the low end (Table 9).

The ratio is significantly less at GR-2 on the high end (10.66 versus 13.19 , a roughly 19percent decrease). The greater rate of dispersal could be attributed to a number of factors, human or natural. Without the artifacts themselves, I cannot confirm human involvement, based on cultural modifications of bone. ${ }^{18}$

There are no Linnean designations in the GR-2 database. Some effort was made to classify mammals by size, in three taxa: small, medium, and large. Nearly one quarter of the specimens were left uncategorized. The taxonomic distribution in Table 17 suggests the possible presence of Artiodactyla among GR-2 fauna, but may be dependent on the visibility bias inherent in large animals (and large animal bone), as compared to smaller on-site fauna:

\section{Table 17: Bone Classified by Mammal Size in Chronological Overlap (GR-2)}

\begin{tabular}{|lcr|}
\hline Mammal Class Size & NISP & \% of Total \\
\hline Large & 258 & 23.78 \\
\hline Medium & 331 & 30.51 \\
\hline Small & 236 & 21.75 \\
\hline Uncategorized fragments & 260 & 23.96 \\
\hline \multicolumn{4}{c}{ Total: } & 1,085 & 100.00 \\
\hline Examples by size-class: Large=deer. Medium=rabbit. Small=squirrel. \\
\hline
\end{tabular}

${ }^{18}$ There are records of burned bone (NISP=32), and of bone associated with features (NISP=37), in the GR-2 database. These are likely incomplete. Of course, bone and other forms of cultural debris have often been excavated from the same unit-level. 
The density of artifacts and features within the excavated portions of GR-2 make clear the longtime, if episodic, presence of humans on site. But the small number of bones in comparison to other cultural remains casts doubt on the GR-2's utility as a hunting camp. Of the 4,099 records in the GR-2 database, only 591 - fewer than 15 percent - mention bone. A mere eight percent of all records fall within the chronological overlap. On the other hand, lithic records - tools, cores, flakes, and debitage - equal 1,267 in the period of 200 B.C.-A.D. 1950. The lithic total is nearly four times the bone count for the same timespan.

Also worth noting is the fact that, while seminar participants have photographed hundreds of unit-levels, lithic and ceramic artifacts, and variously constructed hearths, there is no photographic record for cultural bone at GR-2. The infrequent occurrence and bland appearance of bone fragments militates against picture taking. Prehistoric humans frequented GR-2 for reasons other than animal-resource collection.

Supplementary data: GR-2 macrobotanical analysis

If GR-2 was not primarily a hunting site, then what value did it offer to the humans who camped there periodically for nearly eight millennia? Answering this question is complicated by the fact that the site's economic advantages may have changed over time, based on a variety of unknowable factors. One consistent attribute of GR-2's cultural assemblage is the presence of stone tools and debris. The nearby mountain peaks of Polvadera and Pedernal almost certainly provided the obsidian and chert for many of the lithic artifacts found at the site's every level (Price 2010, Warren 1974). But lithic scatters are common throughout Rio Arriba County, and there are knapping sites more favorably located in relation to local tool-stone sources (GRAB 2009). 
A second possibility is directly related to subsistence. During the Archaic, and into late prehistory, Chenopodium spp. (or "goosefoot") was a primary food plant for the inhabitants of the Northern Rio Grande, who used ground-stone technology for processing seeds. This fact is well attested in the archaeological literature. For example, Bradley Vierra presents ubiquity data for plant remains at archaeological sites in three regional locations spanning a 1,500-year period, starting in 1000 B.C. In each case, cheno-ams ${ }^{19}$ outrank other major forage or domestic plants, including maize, cucurbits, dropseeds, and Indian ricegrass (in Webster \& McBrinn, eds., 2008). Other works that cite evidence for chenopods include Anschuetz and Merlan (2007), Cully and Clary (in Hogan \& Winter, eds., 1983), and M. Toll (in Hogan \& Winter, eds., 1983, in Vierra, ed., 1992). Notes Toll, “...goosefoot seeds are by far the most common economic weed type" found at the prehistoric sites under consideration (in Hogan \& Winter, eds., 1983:334).

This appears to be true at Ghost Ranch as well, based on a macrobotanical study performed by Pamela McBride, an archaeobotanist with expertise in the Rio Chama Valley. McBride analyzed the macrobotanical remains of six flotation samples collected at GR-2 during the 2007 and 2008 dig seasons. She notes that, "The six samples are from strata twoand-a-half to three meters deep in a midden close to a south-facing rock wall and overhang. The samples were associated with fire hearths or cooking platforms...that date to between 4,000 and 6,000 years BP” (2008:2). Economic weeds, especially chenopods, dominate the assemblages: "Plant remains from Archaic layers at [GR-2] indicate a focus on weedy annual seeds and collecting firewood from the piñon-juniper woodland surrounding the shelter"

${ }^{19}$ Chenopodium macrobotanicals are sometimes difficult to distinguish from the remains of a related weedy annual, Amaranthus spp., or "pigweed." As such, they are often grouped together in paleoethnobotanical analyses (Moore 2003, Muceus, pers. comm.). 
(ibid::8). This implies a mid-summer habitation of GR-2 during the period represented by the specimens: "The archaeobotanical record suggests occupation at least from mid-summer, possibly through the fall, although along with spring-ripening grasses and mustards, seeds that could have been harvested in the fall like yucca, prickly pear, and piñon are also absent from the record" (ibid.). Table 18 summarizes the plant taxa identified by McBride:

\begin{tabular}{|c|c|c|}
\hline Scientific Name & Common Name & Plant Part \\
\hline \multicolumn{3}{|c|}{ Annuals } \\
\hline Chenopodium & Goosefoot & Seed \\
\hline Cheno-Am & Cheno-Am & Seed \\
\hline Corispermum & Bugseed & Seed \\
\hline Portulaca & Purslane & Seed \\
\hline \multicolumn{3}{|c|}{ Grasses } \\
\hline Poaceae & Grass family & Culm \\
\hline \multicolumn{3}{|c|}{ Other } \\
\hline Monocotyledonae & Monocot & Stem \\
\hline TBD & Indeterminate & Plant part \& seed \\
\hline \multicolumn{3}{|c|}{ Perennials } \\
\hline Cryptantha & Hidden flower & Fruit \\
\hline Juniperus & Juniper & Twig, seed \& wood \\
\hline Pinus & Pine & $\begin{array}{l}\text { Barkscale, cf. needle spindle } \\
\text { gall, umbo, \& wood }\end{array}$ \\
\hline Pinus edulis & Piñon & Needle \& wood \\
\hline Sphaeralcea & Globemallow & Seed \\
\hline Atriplex/Sarcobatus & Saltbush/greasewood & Wood \\
\hline TBD & Unknown conifer & Wood \\
\hline
\end{tabular}


The collection of summer-ripening seeds suggests an alternative use for GR-2, in the absence of persuasive evidence for specialized hunting. A cautionary note applies: McBride's analysis draws on plant remains dating primarily to the Middle Archaic, in a period prior to GR-2's habitation overlap with GR-145. ${ }^{20}$ As we shall see, it is likely that the site's value to visitors evolved through time, in response to a variety of push and pull factors.

In the next section, I evaluate the data presented here, in the context of the foragingto-farming dynamic of the Northern Rio Grande.

${ }^{20}$ That is, the late Bajada and San Jose phases of the Oshara chronology. There is no indication during this time that foraging peoples of the northern Southwest were domesticating any of the region's economic weeds (Adams \& S. Fish in B. Smith, ed., 2011, Woodbury \& Zubrow in Ortiz, ed., 1979). 


\section{DISCUSSION}

To this point, I have provided a general overview of two Ghost Ranch archaeological sites, GR-2 and GR-145. This overview has been historical in nature, in the sense that it has relied on an eclectic assortment of written records and personal communications from participants in the Ghost Ranch Archaeological Seminar. These first-person accounts have been supplemented with statistical analyses drawn from primary data sources, including a sample of the GR-145 faunal assemblage. Here I start making sense of this information, as a story of economic behaviors in a people transitioning from Archaic to agricultural lifeways, in a late-settled region of the Northern Rio Grande.

Our story so far

As previously described, GR-2 and GR-145 are south-facing rockshelters located five $\mathrm{km}$ apart near intermittent streams or washes in the high-desert country of north-central New Mexico. The sites share strikingly similar socionatural inventories. Excavations at GR-2 have uncovered hundreds of projectile points spanning much of the Oshara Archaic, as well as plant-processing tools, debitage, datable charcoal, late-sequence pots and potsherds, ${ }^{21}$ and a variety of fireplace-types ranging from simple thermal features, to slab-lined pits and "bowl hearths," like those recorded by the archaeologist, Curtis Schaafsma, in the nearby Abiquiu Reservoir District, prior to the Chama River's final impoundment during the 1980s (Figure 19) (Schaafsma 1978). GR-145 has produced similar assemblages, with fewer structured

${ }^{21}$ Ceramic types include Bandelier Black-on-gray, San Juan Red-on-tan, and Potsuwi'i Gray, which indicate possible ties to the protohistoric Pajarito Plateau (Binggeli, et al, n.d.). 
hearths but plenty of fireplace charcoal, stone tools, and lithic and ceramic debris. Excavation at both sites has proceeded along analogous trench-and-transverse lines.

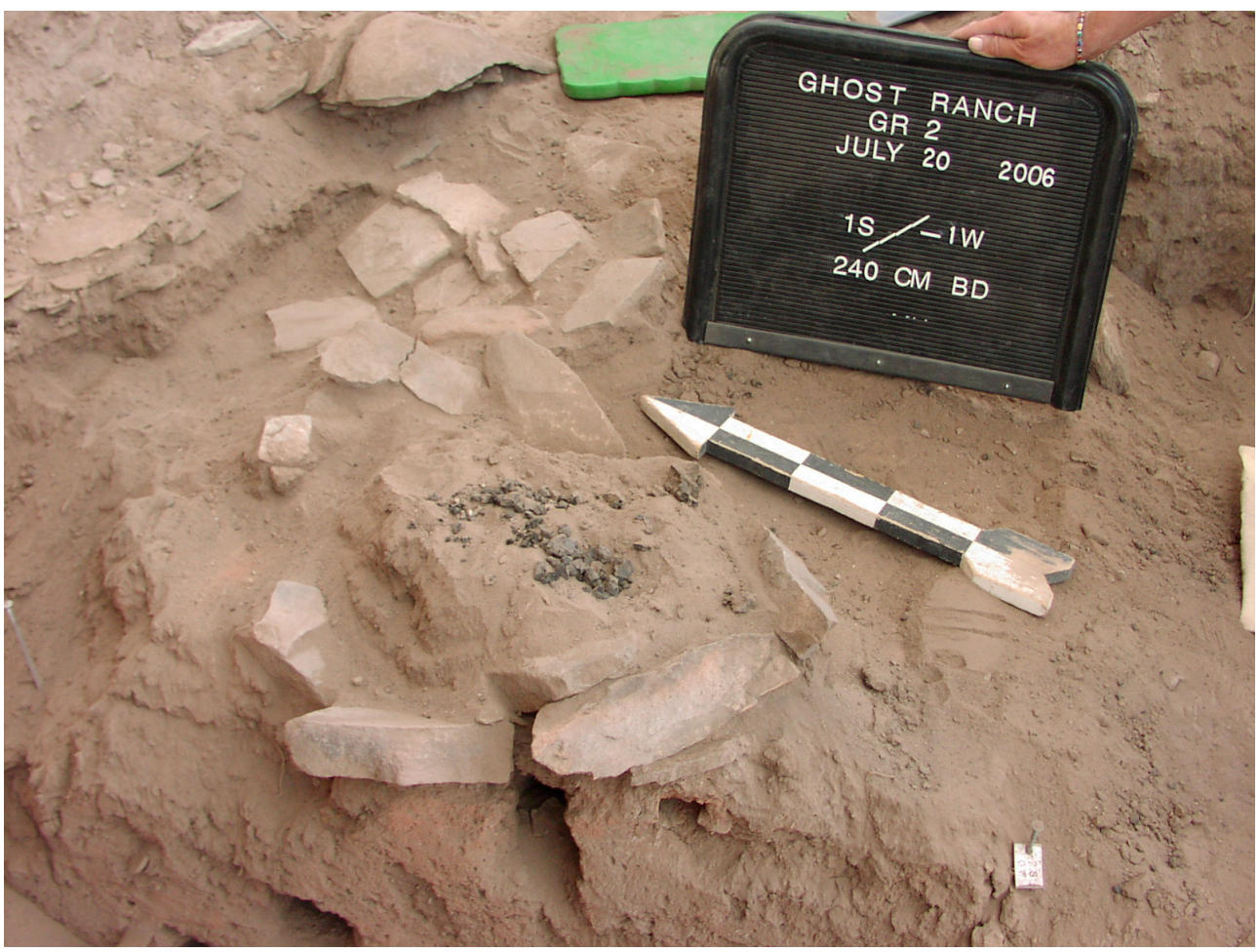

Figure 19. The so-called "double-burner" hearth feature excavated by the author during the 2006 Ghost Ranch dig season. The double burner is a good example of the bowl-hearth phenomenon common in Middle Archaic levels at GR-2. Source: author photo.

The most notable difference in cultural remains at GR-2 and GR-145 is the anomalous bone counts. In light of the evidence, what is the best explanation for this disparity?

\section{Culture or nature}

In archaeology, explanation can be broadly characterized as natural or cultural. That is, the components of archaeological sites are, in some non-trivial sense, determined principally either by people or by natural processes. I do not mean by this that humans are somehow in opposition to the world in which we live. Rather, the long, slow rhythms of site 
formation encompass periods of both habitation and abandonment. Cognitive agency marks the former; unimpeded physical law, the latter. The resulting blend of human presence and absence - the palimpsest environment - is particularly keen in the prehistoric record of hunter-gatherers, for whom transience and seasonality were the defining pulse of existence (Allen 2008, Ingold 2000, Kelly 2007).

It follows from this that demonstrating a significant role for human agency at the Ghost Ranch sites involves disentangling various causal factors, and eliminating competing explanations based on natural processes. The evidence that I have presented makes this possible.

Evaluating natural causes

The first, and most obvious, variable for explaining divergent bone counts at GR-145 and GR-2 is preservation factors related to time. Evidence for habitation at GR-2 extends more than 8,000 years into the past. Corresponding evidence for GR-145, at roughly twothirds the centimeter-depth below datum, reaches back no further than 200 B.C., even with repeated attempts by site crews to find cultural remains dating to the Middle Archaic. Despite this fact, and in the face of more casual assessments regarding the nature of the Ghost Ranch sites, the unadjusted NISP ratio for bone was an underwhelming two to one, GR-145 to GR-2 (Table 7). Might the difference in periods-of-use explain the uninspiring gap in counts? Or was the intuitive assessment of the two sites mistaken, based on greater rates of attrition for bone at GR-2, in post-depositional transport, or in physical and chemical weathering?

Addressing these alternatives was the reason for estimating bone counts in the levels of each site with a common chronology - a period of time when both locations were being exploited by one or more groups of humans. The 5.04:1 ratio of bone, GR-145 to GR-2, that 
occurs in the overlap cannot be explained away purely on the basis of time in the ground, for the simple reason that both sites were in regular use for an identical period.

A second possible cause of the bone-count disparity might be contrasting soil regimes, with markedly different preservative qualities (Banning 2000, Behrensmeyer 1978, Lambert 1997). In other words, is the soil chemistry of GR-2 more taphonomically active with regard to deposited bone than that of GR-145? The $15 \mathrm{pH}$ tests that I conducted at GR-2 and GR-145 appear to preclude this possibility (Table 5). Both sites are composed of alkaline soils separated, on average, by a pH result of 0.11 . In fact, GR-2 is a bit more alkaline than GR-145, which, in theory, makes it a slightly better environment for preserving bone (Lyman 1994). The two sites' $\mathrm{pH}$ ranges are also similar.

A related possibility is that GR-2's bone counts are understated, based on the degree of dissolved bone present in the matrix. Soil tests for elevated phosphate levels can sometimes produce evidence for this type of "invisible bone" (Drewett 2011, Lambert 1997). I found no evidence for biodegraded fauna at GR-2, in two assays that registered only depleted amounts of soil phosphate (Table 6 - admittedly a small sample).

In none of these instances do natural causes appear to be responsible for the difference in bone counts between the Ghost Ranch sites.

\section{Contextual factors}

A second set of factors should be considered - the environmental and geomorphological settings of GR-2 and GR-145. Is it possible that some characteristic of landscape or ecology, affecting site formation or resource collection, served as a constraint on the subsistence options of the groups that visited the sites? 
To a certain extent, this question is chicken-and-egg unanswerable. Humans might willingly choose a resource patch with a reduced menu of options, depending on the value they placed on a particular resource at a particular point in the seasonal round (Jochim 1981, Kelly 2007). ${ }^{22}$ Which is determinative - environmental factors or the human assessment of those factors? Furthermore, in a lifeway of serial relocation, of rounding rather than rootedness, it makes little sense to see, in the selection of a single short-residence campsite, the knuckling-under of humans to a dictatorial environment. Mobility is agency.

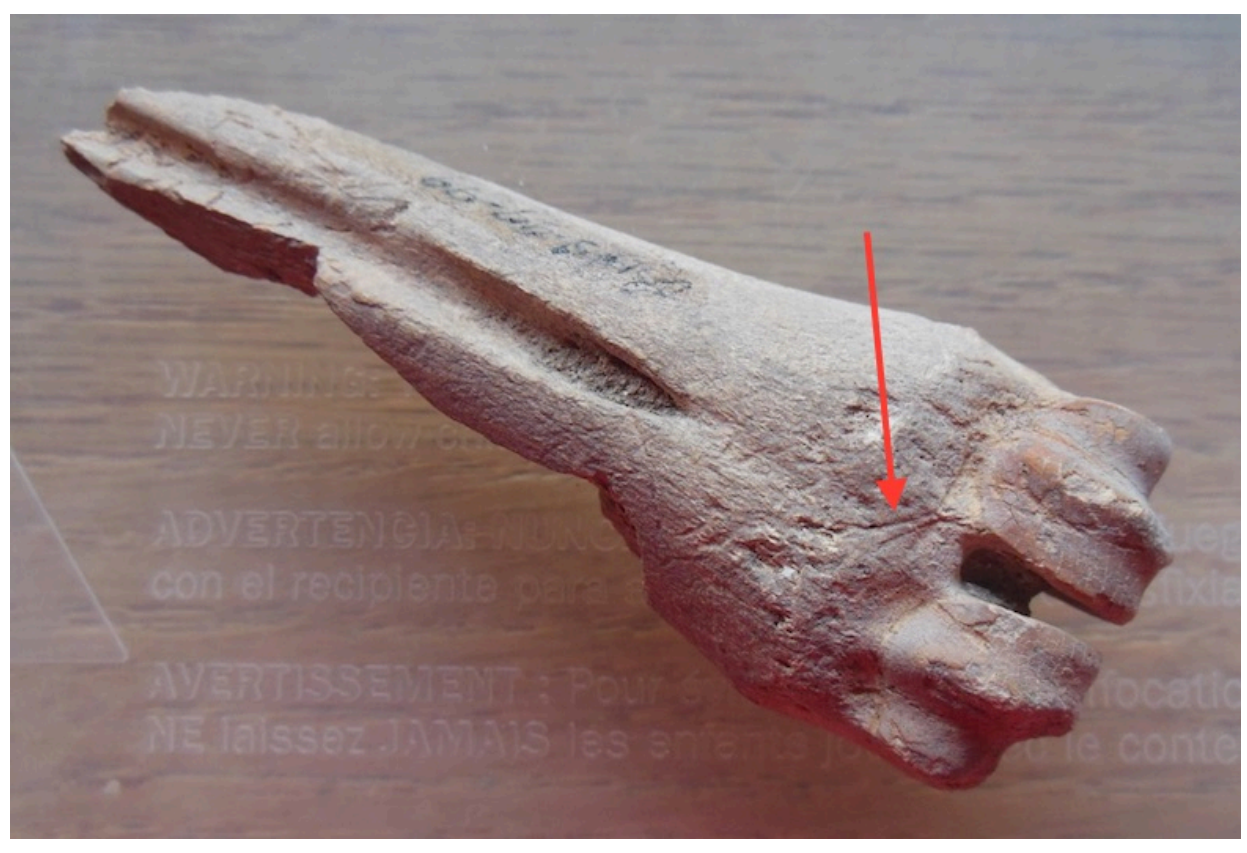

Figure 20. Human-modified bone at GR-145. The red arrow indicates a likely pair of cut marks on the distal end of a fractured artiodactyl metatarsus. Source: author photo.

For all that, there is little in the broader setting that distinguishes the two Ghost Ranch locations. Site-formation processes at GR-2 and GR-145 appear regular if dynamic, as evidenced by the time-depth linear function at GR-2 and the rapid deposition of cultural remains at GR-145. The chief difference between the two sites is related to the downslope

${ }^{22}$ Intensified food collection anticipates the intensified food production of agriculture. 
approach to the primary water source - gradual at GR-2, severe at GR-145. But other than the eroding edge of the GR-145 bench, there is little that is distinctive in this difference. The excavation grid at GR-2 is $12 \mathrm{~m}$ in length, trending away from the bench toward the southeast, but the site itself is a mere $30 \mathrm{~m}$ due east from Bull Canyon Wash, the presumptive source of water. To see this minute inconvenience as influencing behavior, among people who traveled landscapes for a living, is absurd.

The ecological nuances of the two sites can be addressed in a similar fashion. Midsummer GR-145 is wetter and greener than GR-2 - because it sits like a raised beach in the stream channel of the Arroyo del Yeso. Crew chief, John Hayden, describes a riparian botanical community, common along the Rio Grande and its many tributaries, as enveloping GR-145 (site report, Jul. 14, 2005). Many of these same plants, as well as the animals depending on them, are found in the immediate vicinity of the Bull Canyon stream channel. GR-2 is drier partly because it lies at a short remove from the wash. ${ }^{23}$

The failure of various alternative explanations makes it likely that cultural factors the products of human cognition - are behind the divergent bone counts at GR-2 and GR145. Before we consider the implications of these at greater length, I want to touch on an independent line of evidence supporting this conclusion - and some possibly contradictory data as well.

$\underline{\text { Additional evidence for culture: Bull Canyon II }}$

GR-2 is not the only archaeological site being excavated in the Bull Canyon Arroyo. Chris Crews, a doctoral student at Texas A\&M University, has for several seasons been

\footnotetext{
${ }^{23}$ In economic terms, these nuances in landform and ecology generate little marginal utility for site visitors.
} 
digging a site he named Bull Canyon II, in honor of nearby GR-2. Bull Canyon, or BC, II is a third south-facing rockshelter on Ghost Ranch property, lying closer to the wash than its neighbor. Located about $200 \mathrm{~m}(\approx 220$ yards $)$ south of GR-2, it has yielded datable remains from the Developmental Period of the Northern Rio Grande chronology (A.D. 600-1200). The cultural assemblage at BC II suggests the occasional presence of either local huntergatherers or resource-collection parties from population centers located outside the Rio Chama Valley (GRAB 2010) - possibly horticultural groups from the Rio Grande Valley, which were settled between Piedra Lumbre's forager remnants and the bison-hunting inhabitants of northeastern New Mexico (Glassow 1980, Lakatos \& Wilson in Wilshusen, et al, eds., 2012).

To better understand the nature of cooking technology at BC II, Crews analyzed several charcoal samples from fireplace contexts. He discovered that the site's occupants showed a marked preference for firewood from the piñon pine (P. edulis), rather than burning opportunistically any flammable material on hand. This result was unexpected in a highdesert environment of scarce resources, especially considering the close association of piñon pine and juniper species in the forested slopes of the mountainous Southwest. Writes Crews, "Rather than using whatever dried wood was lying around, the prehistoric inhabitants appear to have had a preference for piñon over juniper" (2012:7). He concludes that this preference was cultural, based on knowledge of the burning properties of both tree genera, acquired socially and reinforced through trial-and-error experimentation (2012).

In a similar vein, Crews undertook a microbotanical analysis on the underside residuum of four hearthstones dug by the author at GR-2. The specimens produced the following pollen counts and percentages: 


\section{Table 19: Pollen Counts \& Percentages for 4 Hearthstone Samples (GR-2)}

\begin{tabular}{|lllllrlrrrr|} 
Sample & Pine & $\%$ & Grass & $\begin{array}{l}\% \\
\text { Grass }\end{array}$ & Cheno-ams & $\%$ Cheno-ams & Juniper & $\%$ Juniper & Total \\
\hline 1A & 86 & 18.3369 & 8 & 1.7058 & 1 & 0.2132 & 2 & 0.4264 & 97 \\
\hline 1B & 24 & 5.1173 & 4 & 0.8529 & 5 & 1.0660 & 0 & 0.0000 & 33 \\
\hline 2A & 90 & 19.1898 & 4 & 0.8529 & 1 & 0.2132 & 2 & 0.4264 & 97 \\
\hline 2B & 30 & 6.3966 & 5 & 1.0660 & 0 & 0.0000 & 0 & 0.0000 & 35 \\
\hline 3A & 82 & 17.4840 & 1 & 0.2132 & 0 & 0.0000 & 0 & 0.0000 & 83 \\
\hline 3B & 40 & 8.5288 & 1 & 0.2132 & 0 & 0.0000 & 1 & 0.2132 & 42 \\
\hline 4A & 80 & 17.058 & 0 & 0.0000 & 0 & 0.0000 & 2 & 0.4264 & 82 \\
\hline Total: & 432 & 92.1109 & 23 & 4.9040 & 7 & 1.4925 & 7 & 1.4925 & 469 \\
\hline
\end{tabular}

GR-2's microbotanical data buttresses the firewood findings at Bull Canyon II. In the samples above, piñon-pine specimens outnumber juniper by a wide margin (432:7). Even allowing for some level of impact by airborne pine pollens, this data offers additional support for the presence of cultural behaviors based on human agency at GR-2 (Crews, pers. comm., GRAB 2011-12).

\section{Counter-evidence?}

As I was starting to write my thesis, I discovered a short report, entitled "East Pasture Rock Art," that I had previously overlooked in the Ghost Ranch archives. In it, author Gordon Page, a participant in the archaeological program during its early years, describes a welter of petroglyphs recorded by the 1990 seminar during a survey of a canyon in the vicinity of GR-2. In a key paragraph, Page summarizes the findings thusly: 
"The dominant theme... is hunting. Four-legged animals, birds, [and] arrow representations are dominant. Only two human stick figures were observed among the twenty-three figures. The hunting symbols suggest, in association with the lithic sites below [the panels], that the area may represent a prehistoric hunting shrine" (Jan. 1991:2-3).

Page goes on to further interpret the petroglyphs according to late-prehistoric ethnographic parallels extant at Canyon De Chelly, in the Navajo realm of northeastern Arizona (ibid.).

Though interesting, Page's reading of the petroglyphs is potentially problematic for my thesis. Yes, it verifies the ability of the ancient inhabitants of Ghost Ranch to inscribe their culture on a landscape. However, by raising the possibility that area sites, including GR2, were primarily hunting camps, Page promotes unintentionally a stereotype regarding collection-economy peoples that devalues material evidence located on the sites themselves.
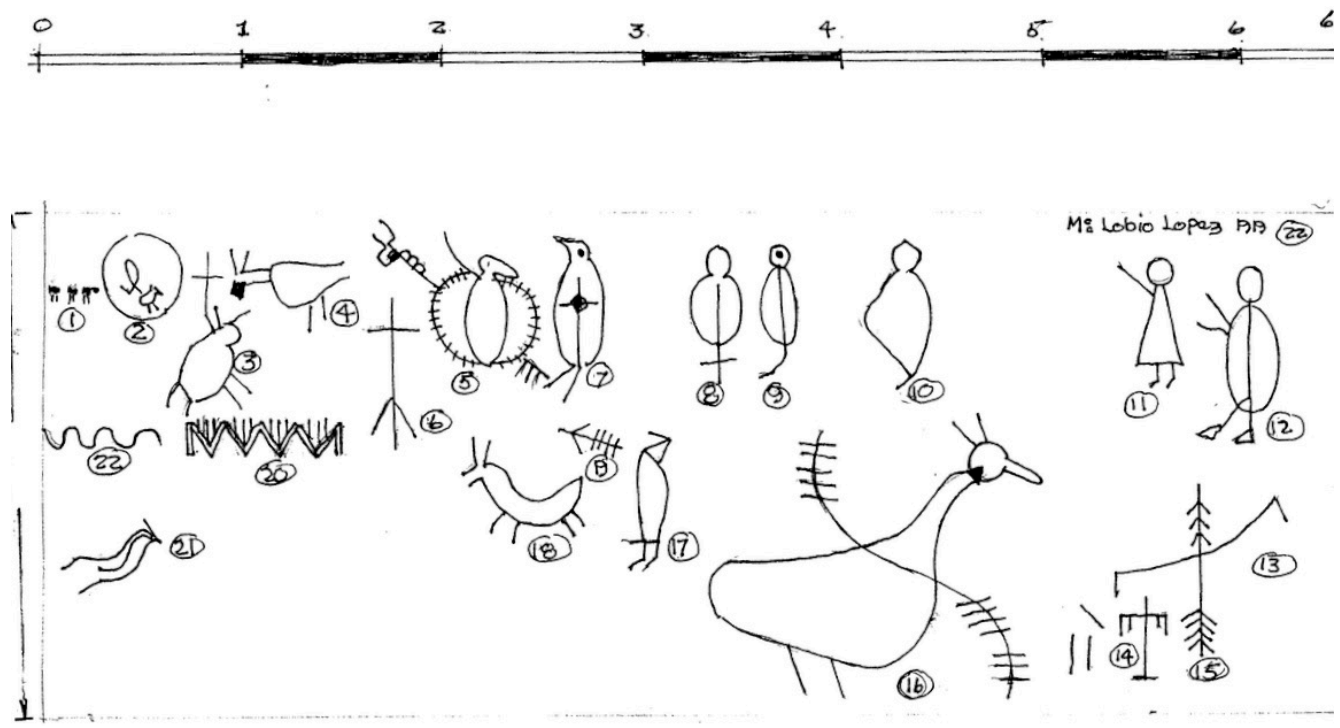

PANEL 1

Scale $4 \mathrm{~cm}=1,0 \mathrm{~m}$.

G.Page-De1. 1/91.

Figure 21: A detailed illustration by Gordon Page of "Panel 1," from a 1990 rock-art survey in the East Pasture of Ghost Ranch, near Bull Canyon Arroyo. Source: Page (1991:6). 
Based on Page's written and visual descriptions, do the Ghost Ranch petroglyphs imply the existence of specialized hunting camps in the Bull Canyon area? Possibly, but there are several reasons for skepticism. First, contra Page, there is no obvious evidence for hunting armories or activities depicted in his reproduction of Panel 1 . The highly abstracted figures are isolated voyagers, in symbolic rather than natural spaces. ${ }^{24}$ Second, the site's lack of dating and ethnographic affiliation means that only the roughest typological comparisons can be asserted. Third, to the extent that real animals are suggested, they do not reflect the traditional game patterns of the prehistoric Southwest. This discontinuity between hunted and depicted animals has been noted elsewhere; for example, in the Upper Paleolithic cave art of southern France and northern Spain (Curtis 2006, White 2003). The recent practice has been to attribute shamanistic rather than hunting-magic qualities to wall-art figures (LewisWilliams 2002, Whitley 2000).

One other difficulty in linking the purview of symbols to a specificity of place comes from the vaguely cited location of the rock-art panels, as described in Page's report (possibly to defend against vandalism). Nevertheless, by using Google Maps, I have prized out the likely location, in a slot canyon to the west of GR-2, at the boundary of the ranch's East Pasture. If I am correct, the rock art is remote enough from Bull Canyon to call into question any facile connection between it and GR-2.

\section{A deeper perspective}

Additional insight on resource use is available from the GR-2 database. The database contains records of all excavated bone through the 2012 season, including specimens from depths predating the chronological overlap. Table 20 compares the bone counts of the

\footnotetext{
${ }^{24}$ The pecked-sandstone medium in which the figures appear is better suited for symbolic representations than subtler, more naturalistic ones.
} 
overlap at both Ghost Ranch sites, with those of the period at GR-2 preceding the overlap, stated in two ways - with and without an early date corresponding to the early date of Pamela McBride's macrobotanical analysis. Despite a longer period of exposure to the elements, bone counts at GR-2 are higher before than during the overlap (albeit at lesser rates of accumulation):

\section{Table 20: Bone-count Comparisons by Time Period (GR-2 \& GR-145)}

\begin{tabular}{lcccr} 
Site & Chronological Period & $\begin{array}{r}\text { Time Span in } \\
\text { Years }\end{array}$ & Bone NISP & $\begin{array}{r}\text { Bone-to-year } \\
\text { Ratio }\end{array}$ \\
\hline GR-145* & 200 B.C.-A.D. 1950 & 2,150 & 5,467 & $2.54: 1$ \\
\hline GR-2* & 200 B.C.-A.D. 1950 & 2,150 & 1,085 & $0.50: 1$ \\
\hline
\end{tabular}

Pre-overlap Period (Earlier Than 200 B.C.)

\begin{tabular}{llccr|} 
GR-2 & Before 200 B.C. & N/A & 1,419 & N/A \\
\hline GR-2 $\$$ & $4000-200$ B.C. & 3,800 & 1,375 & $0.37: 1$ \\
\hline
\end{tabular}

*Chronological overlap. §Early date corresponds with early date of period covered by GR-2 macrobotanical analysis (McBride 2008).

Is it possible that the practice of resource collection at GR-2 changed over time? The database provides a second clue, summarized below:

\section{Table 21: Faunal Sort by Mammal Size (GR-2)}

\begin{tabular}{|c|c|c|c|c|}
\hline Mammal Size & Pre-200 B.C. & $\%$ of Total & $\begin{array}{r}200 \text { B.C.-1950 } \\
\text { A.D. }\end{array}$ & $\%$ of Total \\
\hline Large & 376 & 26.50 & 258 & 23.78 \\
\hline Medium & 409 & 28.82 & 331 & 30.51 \\
\hline Small & 405 & 28.54 & 236 & 21.75 \\
\hline Undetermined & 229 & 16.14 & 260 & 23.96 \\
\hline Totals & 1,419 & 100.00 & 1,085 & 100.00 \\
\hline
\end{tabular}


When the faunal remains from both periods at GR-2 are sorted by mammal size, the data suggests that GR-2 may have been a general-purpose resource-collection camp during the summer months of the Middle Archaic, with evidence for small- and medium-game hunting, occasional large-game hunting, and midsummer harvesting of economic weeds, that gradually fell out of favor as a game-collection site. This interpretation is consistent with the presence of the bowl hearths, which are generally seen as basket holders for cooking meatand-vegetable stews, using water from rainy-season Bull Canyon Wash and fire-heated cobbles (Binggeli, pers. comm., GRAB 2007 \& 2009, Muceus, pers. comm., Schaafsma 1978). It is also consistent with the mix of ground- and chipped-stone tools found on site, including 233 grindstones and 450 Oshara-style projectile points (Figure 22).

Another take is provided by the data in Table 22, which shows the incidence of cultural remains by taxon above and below the overlap horizon at GR-2. A majority of bone dates to the period prior to 200 B.C. -56.67 percent. However, with the sole exception of grindstones (and that only slightly), lithic remains are primarily found in the upper levels of the site:

\section{Table 22: Distribution of Remains Above and Below the Overlap Horizon (GR-2)}

\begin{tabular}{|lrrrr|}
\hline & $\begin{array}{c}\text { At or Above } \\
\text { Overlap Horizon }\end{array}$ & $\begin{array}{c}\text { Below Overlap } \\
\text { Horizon }\end{array}$ & NISP & $\begin{array}{c}\text { Percent Above } \\
\text { Horizon }\end{array}$ \\
\hline Bone & 1,085 & 1,419 & 2,504 & 43.33 \\
\hline Grindstones & 116 & 117 & 233 & 49.79 \\
\hline Lithic flakes & 15,712 & 10,795 & 26,507 & 59.27 \\
\hline $\begin{array}{l}\text { Projectile } \\
\text { points }\end{array}$ & 331 & 119 & 450 & 73.56 \\
\hline Lithic cores & 295 & 97 & 392 & 75.26 \\
\hline \begin{tabular}{l} 
Overlap horizon $=\mathbf{2 0 0}$ B.C. \\
\hline
\end{tabular}
\end{tabular}


The stone-bone disparity argues for long-term change at GR-2, from a generalized resource-collection camp to a stage in a widely distributed operational sequence for stonetool production in the Rio Chama Valley. This is somewhat surprising, given the relatively remote location of GR-2 from the sources of Pedernal chert or Polvadera obsidian. It may be significant that only the grindstones - a plant-processing tool - are evenly distributed above and below the overlap horizon. Also of note is the fact that an increase in projectile points occurs during the period when overall evidence for animal capture declines.

GR-145 tells a different story. It is a hunting camp rooted in the Late Archaic, during the period shortly preceding agriculture's arrival in the Piedra Lumbre Basin. The highvolume bone counts and butchery anvil argue for the onsite practice of hunting expertise game capture, processing, and consumption. A fall and wintertime occupation is suggested by large quantities of intensely worked artiodactyl long bone (Tables 10-15; see also Osborn 1993). Thanks in part to limited rainfall and short growing seasons, foraging trumped farming in the Middle Rio Chama Valley until the last years of prehistory (Post in Vierra, ed., 2013). "As a result, many groups relied more on hunting artiodactyls to provide for their subsistence needs," writes Nancy J. Akins (in Vierra, ed., 2013:226).

There are other reasons for seeing the sites as differentiated by use. GR-145 is smaller than GR-2, limited to the dimensions of the bench where it is situated. A narrow footprint would have curtailed its usefulness for any group larger than a highly mobile hunting party. On the other hand, GR-2 shows a greater diversity of material remains in a larger footprint, with more elaborately constructed hearths than GR-145, implying season-long occupations. This suggests residence by family groups engaged in wide-ranging resource collection. 
The two sites together, similar in setting but differentiated in use, trace the development through time of specialized economic behaviors that anticipate the divisions of labor and productions of surplus that characterize sedentary farming societies. Ghost Ranch archaeology offers a window, however slight, into one of the defining episodes of modern humanity.

A purpose for culture

"The cornerstone of the scientific method is the postulate that nature is objective. In other words, the systematic denial that 'true' knowledge can be got at by interpreting phenomena in terms of final causes - that is to say, of 'purpose'."

- Jacques Monod, Chance and Necessity (1972:21)

The hunter-gatherer sites of GR-2 and GR-145 offer evidence of differentiated use through time, resulting from cultural rather than natural factors - human decisions rather than environmental constraints. As the final step in my analysis, I plug this data into a larger story about the coming of agriculture to the prehistoric Rio Chama Valley. I see in the practice of specialized activities at discrete locations the formation of a psychological predisposition essential to the rise of food-production societies. Spatially separated skill sets were a necessary precondition for the increasingly complex divisions of labor that we associate with a field-and-village lifeway. I start here by exploring the divergent paths of culture and biology in human affairs.

Exaptation vs. pre-adaptation

The onetime common use by evolutionary biologists of the concept of pre-adaptation has come under fire in recent decades. Originally, a pre-adaptation was any phenotypic trait that appeared to deliver a Darwinian advantage by anticipating future shifts in environment. By suggesting a kind of preparedness for change, pre-adaptation hinted at design in natural 


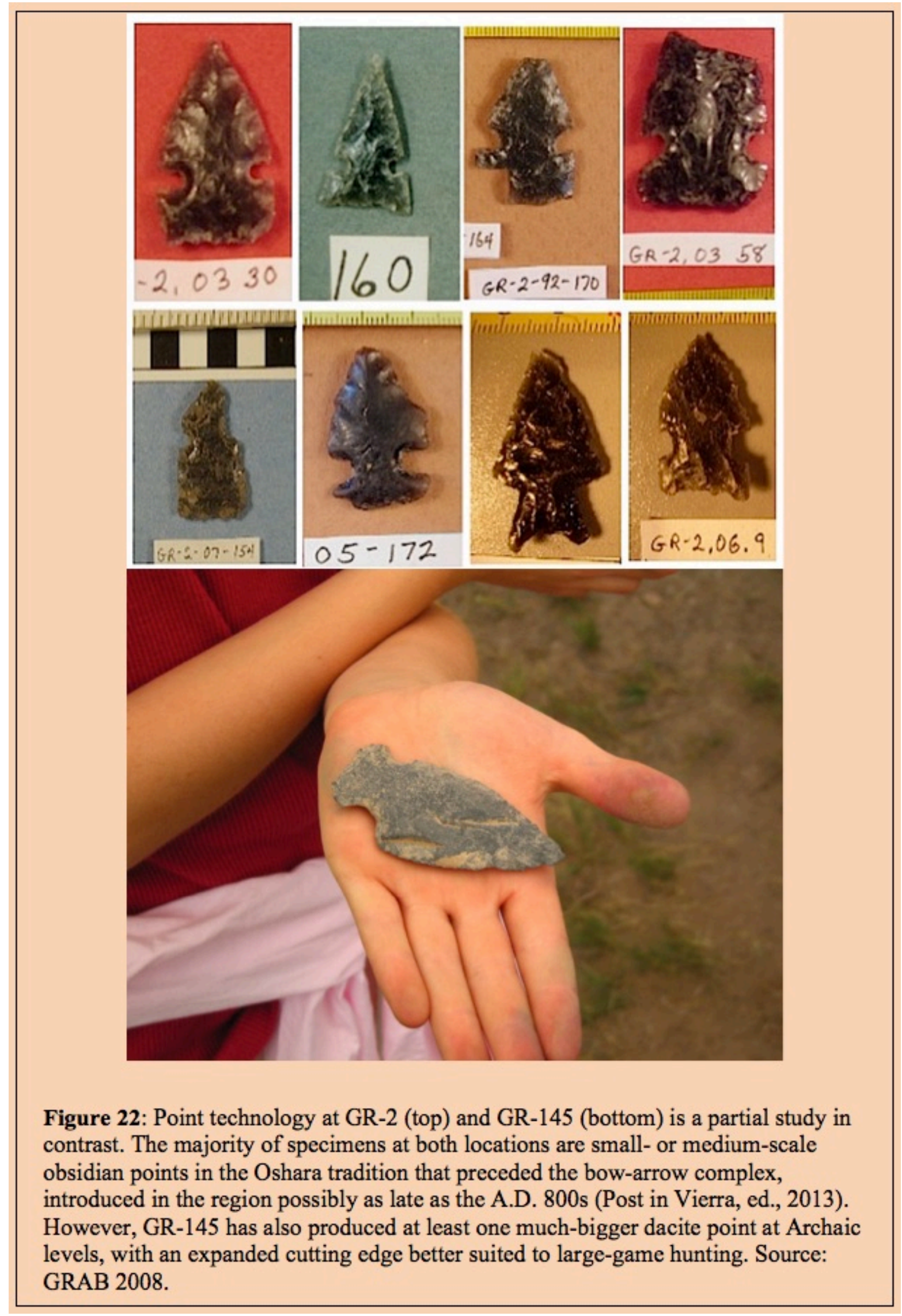


selection. But the idea of goal-directed change in evolution is an anathema to most scientists, as noted by Monod above. ${ }^{25}$ According to Ernst Mayr, "The one thing about which modern authors are unanimous is that adaptation is not teleological, but refers to something produced in the past by natural selection" (1983:324).

In a 1982 article, Stephen Jay Gould and Elisabeth Vrba provided an elegant fix for the seeming paradox of evolutionary preparedness. They introduced the term, "exaptation," which purged the pre-adaptive phenomena of its predictive elements. Exaptations are harmless, non-adaptive traits in a particular environment, which become adaptive through a change in circumstance, but without precognition of that change. All "reasonably complex traits are likely to represent a layering of exaptations and adaptations," says Anita Thanukos (2009:613). Biology trudges ever onward, with eyes fixed firmly on the ground.

Does this mean that the notion of pre-adaptation has no place in the life sciences? There is a case for pre-adaptation: but only (so far) in humans. This is because Homo sapiens is the one species on Earth with evidence to date for possessing complex culture, meaning the intergenerational accumulation of social capital, by way of imitation, learning, and long-term storage of knowledge. ${ }^{26}$ In Not by Genes Alone, Richerson and Boyd (2005) argue that culture has become an independent force in human evolution, with a trajectory at least partly separated from biology, as evidenced by voluntary declines in reproductive fitness in industrialized nations since the mid- $19^{\text {th }}$ century. Put another way, culture has begun selecting against biology.

\footnotetext{
${ }^{25}$ Monod goes on to maintain that modern science, at heart, is the triumph of statistical correlations over Aristotelian causation (1972).

${ }^{26}$ As the cultural anthropologist, Lee Cronk, puts it, "Culture is neither the act of baking the cake nor the cake itself, but the recipe, the socially transmitted information that tells a person how to bake a cake" (1999:12, emphasis his).
} 
Other scholars have championed the adaptive and heritable characteristics of culture, while distancing these from a too-literal Darwinian reading (Alvard 2003, Henrich \& McElreath 2003). ${ }^{27}$ In other words, culture, while derived from biology, operates in the manner of a prodigal son. A major distinction between the two is the role that language has in human cultural affairs. Though other animals communicate, only humans have a vehicle for expressing their awareness of time, as indicated by the various tenses and relational taxa in language (e.g., lineage or multigenerational kin groups) (Geertz 1973, Hodder 2006). Likewise, only humans have invested heavily in externalized storage of knowledge, especially in media - from stone and fired clay, to museums and mainframe computers - that outlast the individual lifespan. These are critical clues, I think, to culture's deeper purpose. I propose that culture is the human means of pre-adaptation, that is, adaptation to hypothetical future states, based on the best information available to social groups at any one time and place. Said differently, culture is, if not teleological at least anticipatory and guess-directed, and proceeds by estimating future states so as to pre-adapt humans to environmental change. Culture moves forward, with eyes set firmly on the horizon. $\underline{\text { Economic agency - an engine of cultural evolution }}$

Complex culture is complex - that is, ultimately irreducible to its constituent elements. ${ }^{28}$ We should not, however, allow this fact to prevent us from identifying patterns of behavior that are preponderant in determining successful outcomes in the cultural realm. We can categorize one of these sets of behaviors - there are others - as economic agency.

\footnotetext{
${ }^{27}$ For example, Richard Dawkins's meme, which is a theoretical construct for forcing cultural heritability into a discrete, Darwinian unit (1989).

28 "Or, to put it differently, the existence of the structures with which the theory of complex phenomena is concerned can be made intelligible only by what the physicists would call a cosmology, that is, a theory of their evolution," writes Friedrich Hayek (1967:76).
} 
What is economics? Lionel Robbins defines it as "the science [that] studies human behavior as a relationship between ends and scarce means which have alternative uses" (in Gwartney \& Stroup 1997:6). Agency refers to choice making; economic agents select among competing means and ends, based on a hierarchy of values and their associated costs. A traditional anthropological application of economics is to exchanges among non-kin relations (e.g., Herskovits 1952). But economic thinking in the broadest sense can be extended to any budgetary process - including the nutrition and energy budgets of human subsistence regimes (Jochim 1981, Schneider 1974, Whitney \& Rolfes 2005). Bruce Winterhalder and Carol Goland provide an example of the latter, in their use of a diet-breadth model to explain the domestication of the economic weeds of the Eastern Agricultural Complex (in Gremillion, ed., 1997), adding intentionality and calculation to David Rindos's Darwinian substrate (1984).

Employing economic agency to explain the gradual substitution by Archaic populations of food production for food collection has direct relevance to the archaeology of Ghost Ranch. Millennia of managing a seasonal round created in hunter-gatherers a psychological apparatus for weighing alternate strategies, based on estimated future returns (Winterhalder \& Goland in Gremillion, ed., 1997). This resulted, over time, in a move from the generalized subsistence strategy apparent at GR-2, to a site-based focus on particular resources - artiodactyl hunting at GR-145. Greater food yields generated positive feedback for the specialized behaviors associated with productive sites. The cost traps of time and effort in developing skill were recast as investments with future advantage (Fuller, et al, 
2010). Nascent divisions of labor emerged, pointing the last hunter-gatherers in the direction of agriculture. $^{29}$

Cultural evolution in the Rio Chama Valley

As previously noted, food-production systems appeared late in the Rio Chama Valley, compared to other locales of the prehistoric Southwest (Lakatos \& Wilson in Wilshusen, et al, eds., 2012). Here I present a broader perspective on the origins of agriculture, as context for the findings at Ghost Ranch.

In recent years, investigators have resolved one of the evergreen conflicts of Southwestern archaeology: when the major Mesoamerican cultigens (including maize) first appeared. A raft of new AMS-radiocarbon dates have confirmed the early arrival and rapid spread of agricultural staples across much of the Southwest (Raloff 1993, Simmons in Doyel \& Dean, eds., 2006). Whether this occurred by diffusion or migration (or both) remains an open issue (Hill 2002, LeBlanc in Webster \& McBrinn, eds., 2008, Matson 1991, Vierra in Minnis \& Redman, eds., 1990, Wills 1988, in Price \& Gebauer, eds., 1995). Table 23 lists selected early dates for evidence of maize in cultural contexts. Jemez represents the oldest securely dated presence in the Northern Rio Grande Valley (Vierra \& Ford in Vierra, ed., 2007); it is the closest site to Ghost Ranch:

${ }^{29}$ In other words, foragers chose farming, in part, as the optimal subsistence regime for deploying specialization, rather than being forced into farming by circumstance, only to be rewarded by the accidental discovery of its beneficial economics. 
Table 23: Selected Early Dates for the Appearance of Maize in the Southwest U.S.

Site

Chaco Canyon, New Mexico (pollen)

Old Corn Site, New Mexico (cobs)

Bat Cave, New Mexico (K/h/f)

Milagro, Arizona (K/h/f)

Three Fir Shelter, Arizona (K/h/f)

Jemez, New Mexico (K/h/f)
Dates (BP)

$3940-2450$

$3680-3620$

$3010 \pm 150$

$2930 \pm 45$

$2880 \pm 140$

$2410 \pm 360$

After Benz, in Staller, et al, eds., 2009, Hall 2010, and Staller 2010. Bat Cave dates based on Wills (1988). K/h/f =Kernels, husks, or fragments. All dates radiocarbon $A M S$.

The caveat to early-and-fast dispersal is that the spread of agriculture was a piecemeal process. In other words, early adoption was wider than it was deep (S. Fish \& P. Fish 1994). According to Linda Cordell, "By 100 B.C., corn is known from sites everywhere from Chihuahua to Colorado and Sonora to Utah, although not all people living in this vast area used domestic crops" (1997).

Given the pitiless environment, why did ancient Southwesterners adopt agriculture? Archaeologists have decided on an explanation involving economic agency. Contra Berry and Berry (in Condie \& Fowler, eds., 1986), the introduction of maize and other cultigens was not transformational; rather, it was an accretive process, in which the southern plants first proved their worth as insurance or fallback resources. Human supervision "ranged from encouragement to management to cultivation" (Adams \& S. Fish in B. Smith, ed., 2011:158). Intermittent and low-cost food production provided hunter-gatherers with a cushion for lean periods in their seasonal round. In time, successful risk management led to reduced mobility and renewed investments in cropping (B. Smith 1995, Flannery, ed., 1986, Huckell 1996). 
With increased settlement came increased population, especially in lowland settings most favorable to farming. Hunters from agricultural villages invaded the uplands looking for game that was depleted at home; this forced rump groups of hunter-gatherers into a defensive territoriality more conducive to farming than foraging. W.H. Wills sees in this dynamic a "culture pump" process that gradually drove agricultural substitution across the whole of the American Southwest (1988, in Price \& Gebauer, eds., 1995). I would add to Wills's stick the carrot of productivity. The final foragers glimpsed, in nucleated, year-round settlements, the value of an alliance of skills first developed at dispersed sites in the seasonal round. Primary forage plants

While this process was underway, which plants did humans target for consumption? Already noted as prominent was Chenopodium or goosefoot, along with weedy annuals such as purslane (Portulaca spp.) and Rocky Mountain beeplant (Cleome serrulata) (Dunmire \& Tierney 1995). Evidence for goosefoot, and its cladic cousin pigweed (Amaranthus spp.), is common to commanding at archaeological sites throughout the Southwest (e.g., Bohrer, et al, 1969, Carter 1945, Fry \& Hall 1975, Kent 1991, M. Toll in Hogan \& Winter, eds., 1983). “A broad Southwest summary confirms the widespread use of cheno-am seeds, bugseed, tansy mustard, and purslane, along with dropseed and ricegrass grains, at times as staples" (Adams \& S. Fish in B. Smith, ed., 2011). Goosefoot's niche as an early colonizer of disturbed environments meant that it came into regular contact with humans, who are second to none in upsetting equilibria (B. Smith 1995).

By flourishing in anthropogenic settings, goosefoot also shared the landscape with corn, which was bred by humans as part of a food-production strategy that suspended ecological succession (Altieri 1995, Woodbury \& Zubrow in Ortiz, ed., 1979). Eventually 
goosefoot switched from being a primary forage plant, to being an opportunistic squatter on the cultivated fields of the Southwest - so much so that archaeologists now use its remains as a marker for oldfield agriculture (Rose 2004). But goosefoot was never domesticated in western contexts. The chenopods lost out to maize as a cornerstone lifeway plant, because corn's diversity allowed it to adapt to man's many agricultural niches, giving it a competitive advantage over aggressive, sun-loving interlopers like goosefoot (Gremillion 1993, Mohler \& Callaway 1995, Muenchrath \& Salvador in W. Toll, ed., 1995). ${ }^{30}$ At the same time, by offering itself up as a long-term experiment in marginal food production, goosefoot preadapted foragers to farming.

\section{Evidence for corn}

Agriculture debuted in the Rio Chama Valley around A.D. 900, at the time of the prototype pueblos (Vierra in Staller, et al, eds., 2009). The earliest settlements appeared suddenly and more or less together, as centrally coordinated projects. "Room blocks were erected in large-scale building episodes involving dozens of rooms simultaneously rather than according to the whims of each household separately," writes Severin Fowles (in Adams \& Duff, eds., 2004:20). Defensive considerations were likely paramount, but the abrupt colonization of an Archaic landscape by agriculturalists with a variety of specialized skills would have intensified the evolution of kin- and pueblo-centered divisions of labor. ${ }^{31}$

\footnotetext{
${ }^{30}$ Maize plants are monoecious and protandrous, meaning that they contain, separated on the same plant, both male and female flowers, and that these flowers mature at different times, leading to considerable cross-pollination with nearby plants. Corn kernels are typically heterozygous and heterogeneous, creating extraordinary genetic versatility - more so than Chenopodium, which scatters its diversity among several introgressing species (Crawford 1975).

${ }^{31}$ Fowles sees subgroup specialization and exchange relations developing over time, from more generalized household economies (in Adams \& Duff, eds., 2004). Hodder notes a parallel process at Çatal Höyük's East and West Mounds (2006).
} 
Farming's arrival meant corn's arrival in the Rio Chama Valley. Direct evidence comes from a variety of early-published reports, representing the first wave of archaeological survey and excavation in the area. J.A. Jeancon describes charred corn at Pesedeuinge (1912) and manos and metates, used in grinding corn, at Poshuouinge, near Abiquiu (1923). In addition to ground-stone technology, Frank Hibben found evidence for what he figured was "the remains of ancient maize terraces" at the Riana Ruin, located today near the Abiquiu Reservoir (1937:17). Ralph Luebben describes mealing bins and the "charred corn cobs and husk fragments of Zea mays" at Leaf Water, a pueblo in the Lower Rio Chama Valley (in Wendorf, ed., 1953:30). Mealing bins and knotted cornhusks were reported at the Palisade Ruin, also near the reservoir (author unknown, n.d.).

Analyzing paleofecal samples from the Four Corners region, Paul Minnis concludes that corn was "the single most ubiquitous and abundant plant food consumed" during this period (1989:559). Although farmers continued to supplement their diet with goosefoot and other field-invaders (Hocking 1956, Schmidt 2007), maize developed into the flagship crop of the new subsistence regime (Martin 1999).

Accompanying corn at the Rio Chama pueblos were inventive combinations of agricultural features unusual for farmers in the prehistoric Southwest (Maxwell \& Anschuetz in Killion, ed., 1992). David Buge describes a complex of fields, gardens, and hydrological features at six sites near the Rio Ojo Caliente, a tributary of the Rio Chama, dating to the protohistoric period (in S. Fish \& P. Fish, eds., 1984). These features allowed the inhabitants to utilize the entire geophysical environment for farming, with systems designed to support 
both dry (terrace) and floodwater farming. ${ }^{32}$ Innovation extended to crop choice; archaeobotanist, Glenna Dean, has recorded the northernmost early evidence for cotton production in this same general area (in H. Wolcott Toll, ed., 1995).

Of particular note are the rock-mulch gardens, which slowed erosion, managed soil moisture, and sheltered seedlings from wind damage. Doolittle documents a "possible prehistoric seedbed in northern New Mexico" and reports on Richard Lang's experimental confirmation of the moisture-holding properties of pebble mulching (2000:116\&249). "This allowed the [inhabitants] to expand arable land into areas previously considered less suitable for agriculture and improved the productivity of existing croplands," according to Lightfoot and Eddy (1995). After a brief but brilliant run, however, these farming communities faded or failed, leaving the region for good. By the $17^{\text {th }}$ century, Navajo sheepherders had replaced pueblo agriculture with a pastoral lifeway (Schaafsma 2002, Weisiger 2004).

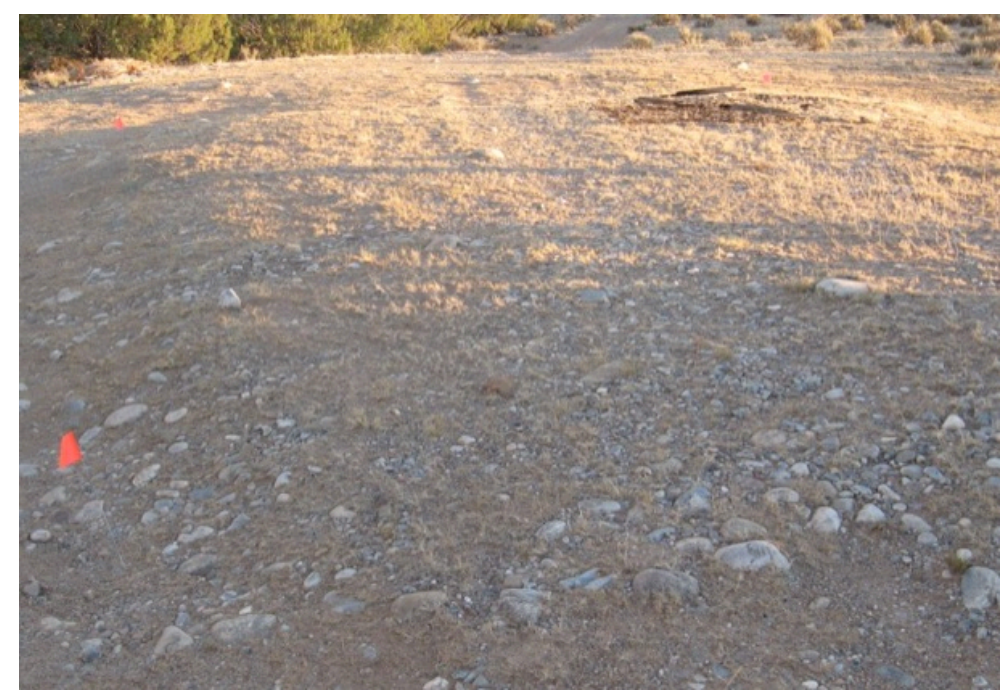

Figure 23: Rock-mulch remains at Sapawe in the Rio Chama area. Agronomists have shown their efficacy experimentally (Lamb \& Chapman 1943). Source: author photo.

${ }^{32}$ Floodwater, or $a k$-chin, farming took advantage of natural irrigation in the alluvial basins and river valleys of the prehistoric Southwest. The geologist, Kirk Bryan, categorized it as being more like planting than farming (1929). 
Exemplifying the pattern: GR-2 and GR-145

Using this context, we can situate the Ghost Ranch sites in the foraging-to-farming transition, as repositories for material remains from the early stages of this process. GR-2 was a resource-collection site for chenopods and other weedy annuals, as well as a generalized hunting camp for various-sized mammals. Based on bone counts, hunting success may have declined over time, but the information transmitted by multiple generations of goosefoot harvesters would have eased the eventual conversion of their descendants to a food-production economy (assuming continuity of population). ${ }^{33}$

Current evidence suggests that GR-145 was a large-game hunting camp closer in time to agriculture's arrival. The lack of an Anasazi presence implies visitation by Archaic remnants or possibly Rio Grande horticulturalists, rather than task groups from the San Juan Basin (Duwe \& Anschuetz in Vierra, ed., 2013, Lakatos \& Wilson in Wilshusen, et al, eds., 2012, Whitten \& Powers 1980). I see the site's occupants as developing specialized skills required by farming societies, which come together in villages and towns to establish rudimentary divisions of labor, with associated gains in wealth and fertility. Isolated cultural spaces in an unbounded landscape evolved into dedicated work-zones in pueblo roomblocks. ${ }^{34}$

But if the link between wild-plant collection and agriculture is clear, how did the hunting expertise visible at GR-145 and other like sites prove valuable to the farmers of the Rio Chama Valley? The answer lies in the complementary nature of hunting and farming,

\footnotetext{
${ }^{33}$ Some in-bound migration to the Middle Rio Chama occurred but it is insufficient to explain the foraging-to-farming transition (Cordell in Cordell \& Gumerman, eds., 1989). 34 The ultimate origin of factories lies in the enclosure of operational sequences for gains in efficiency. Some tools - looms and kilns, for instance - are more like features than artifacts.
} 
which was facilitated by another fortuitous event: the local appearance of the bow and arrow about A.D. 800 (Post in Vierra, ed., 2013).

Complementarity of hunting and farming

Hunting was an economical means for Native American groups to achieve a variety of dietary and social goals. According to Beaglehole and Sapir, the Hopi rely on hunted game as a critical source of energy and nutrition; as a relief from the tedium of agriculture; as a critical path for male socialization and solidarity; and as a canvas for working out ritual and religious obligations (1936). Similar concerns are found among other Pueblo Indian groups (Cushing 1979, Dutton 1983), the Navajo (Reichard 1950), and the Western Apache (Buskirk 1986).

But the bow and arrow changed how Indians hunted. Where safety required it, Native Americans continued to pursue game in groups (Beaglehole \& Sapir 1936), but the switch in primary hunting technology from atlatl to bow gradually individualized the process. Spears worked best bristling at close range to trapped animals; the bow and arrow favored the single stalker shooting from undercover (Judge in Plog \& Wait, eds., 1982). Lightweight bows also offered advantages to hunters tracking prey over greater distances (Laubin \& Laubin 1980), an expected outcome of late prehistoric population growth and sedentism.

The most important of the large-game animals was the mule deer (O. hemionus). Hunters traditionally pursued deer during the rut, when they were most vulnerable. At this time of the year, typically late fall or early winter, bucks and does congregate, for mating and fighting purposes (Heffelfinger 2006). Normally skittish males become bellicose but are also more approachable. "This hunting strategy is one of slow stalking, concealment, and attraction of the deer prior to shooting," notes Bruce Smith (1975:37). In addition to the bow, 
which was ideally suited for this type of prey taking, hunters utilized deerskin camouflage, deer-head masks, faun calls, and other forms of decoy and trickery (Buskirk 1986, James in Redman, et al, eds., 2004, Kroeber 1961, Pope 2010). ${ }^{35}$

With human presence pressuring local pockets of prey, hunters were forced to travel farther and farther from settlements to locate harvestable game (Dean in Dean, ed., 2010, Linares 1976, Mick-O’Hara in Vierra, ed., 1992). Field-grown foods made the risk of longdistance expeditions affordable, enabling hunters to integrate the thickly settled lowlands with the sparsely inhabited uplands (Speth \& Scott in Kent, ed., 1989, Szuter \& Bayman in ibid.). The result was the rise of a class of hunting specialists, who supplied families, villages, or feasting elites with game. Steven James sees evidence for these specialists in the ritual settings of Hohokam pithouses, associated with bighorn sheep skulls, horn cores, and caches of exotic toolstone (in Redman, et al, eds., 2004). The naturalist, William Bartram, describes one, "loaded with meat, hides, and honey," who was traveling with his family in the Carolinas (1995:64).

In general, an escalating emphasis on productivity - that is, the increased focus by bow-armed hunters on a limited repertoire of game - complemented regimes of population growth, sedentism, burgeoning political complexity, and a high agricultural portion. Farming and hunting comprised a single intensified continuum of subsistence, providing essential nutrients and cultural identities for the surging communities of the late prehistoric Southwest (Barlow 2002, Glassow 1980). Each funded the growth of complexity; each produced

\footnotetext{
${ }^{35}$ Artiodactyl remains, including deer, are well evidenced at GR-145. A variety of bird bone is also onsite, much of it burned. In addition to Wild Turkey (M. gallopavo) remains, larger birds such as the Sandhill Crane (Grus canadensis) may be represented. New Mexico hosts a major migratory flyway, and cranes are reported seasonally in the bosque environments of the Rio Grande and Rio Chama Valleys (e.g., Lent 1991). Depending on period of residence by humans, this would time reasonably well with the mule deer rut.
} 
surpluses that underwrote elites like those at Chaco, who managed populations as human capital for a variety of social and religious projects (Lekson 1999, Lekson, ed., 2006, Sebastian 1992). GR-145 was part of a large-scale reconfiguration of dietary regimes that ramped up production of both plant and animal resources.

Down the line to GR-145

A final strand of evidence indicates that GR-145 was more closely tied than GR-2 to the growing cosmopolitanism of the Northern Rio Grande late in prehistory. Ghost Ranch crews have excavated two polished Olivella shell beads at GR-145. Olivella is a genus of predatory, saltwater snails found in the Gulf of California (Rehder 1981). Shell presence at GR-145 suggests that the hunters who camped and butchered there participated in down-theline trade relations that ultimately extended hundreds of miles to the Mexican coast. Similar exchange networks are associated with politically complex, capital-intensive Chaco Canyon (Ericson \& Baugh 1993, Mathien in Mathien \& McGuire, eds., 1986, Vargas 1995).

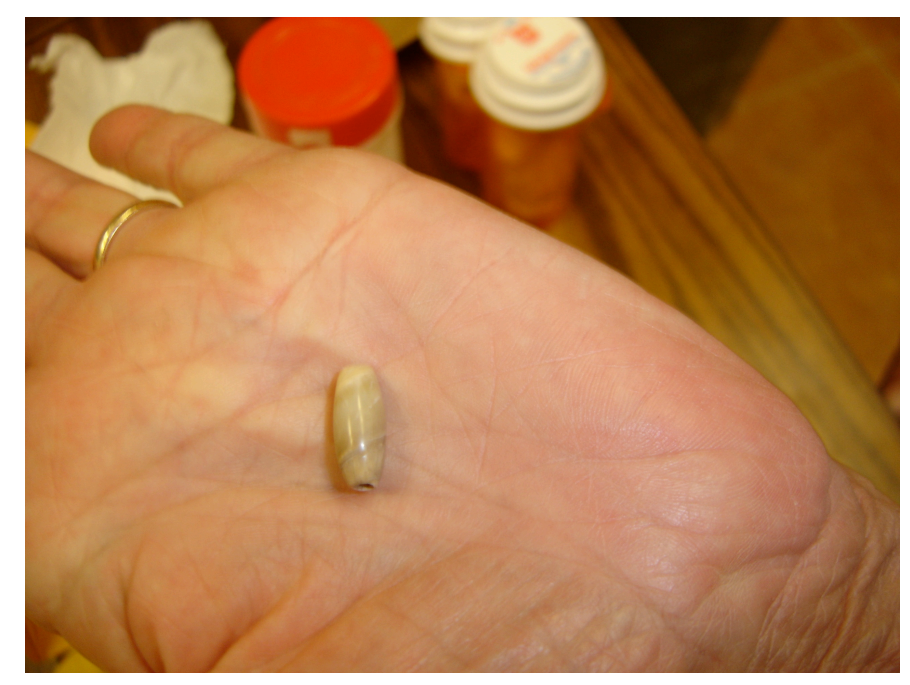

Figure 24. A polished Olivella shell bead, one of two discovered at GR-145. Olivella is a genus of predatory, aquatic gastropods sourced to the Gulf of California, among other places. Source: author photo. 


\section{Three regimes}

Three major subsistence regimes are evident in the long settlement of the Rio Chama Valley, in which GR-2 and GR-145 play minor contributory roles. Archaic peoples collected a mix of plant and animal foods as part of a hunter-gatherer diet. The farmers of the pueblo period replaced Archaic foraging with agricultural food production, supplemented by incidental collection and long-distance hunting. Finally, Athapaskan peoples in the historic period switched to pastoralism, herding animals introduced by the Spanish.

Subsistence turnover, or succession, is evidence of agroecology and human-managed landscapes (Altieri 1995, Gilman, et al, in Thompson \& Waggener, Jr., eds., 2013). This is significant, because it implies that cultural selection was at work in the choices that people made about lifeways. Steven James offers additional evidence: Despite living near the Rio Chama, the peoples of the region never incorporated fish into their diet and diet-related behaviors (in Redman, et al, ed., 2004). Other cultures of the ancient Southwest certainly did - witness the osteological remains at Hohokam sites and the pot-depicted fish of the Mimbrean Mogollon (Brody in Riley \& Hedrick, eds., 1978, Fewkes 1989). But I can confirm James's point with regard to the Rio Chama Valley. In more than 35 combined years of Ghost Ranch excavation, we have never found a fish bone, bone hook, or net weight at either GR-2 or GR-145. Foodways are facets of culture, derived from both reason and shadow. 


\section{SUMMARY AND CONCLUSION}

I began by suggesting that, if archaeologists looked beyond the discipline's ingrained visibility bias, there was something to be gained by placing the sites of the Southwestern Archaic within the sweep of total history - Braudel's (and Hodder's) longue durée. I have tried to do just that, by analyzing the material remains of GR-2 and GR-145 within the context of the foraging-to-farming transition in the Northern Rio Grande. Few question the central importance to humanity of the change in the primary mode of subsistence that has taken place nearly everywhere, either culturally (Richerson \& Boyd 2005) or biologically (Cochran \& Harpending 2009). The relatively recent occurrence of this transition, within a superior preservative environment, makes locations like the Piedra Lumbre Basin attractive for investigating the topic.

I see the Ghost Ranch sites as signifying, in the material effects of economic agency, the psychological changes that were occurring in a people increasingly inclined toward sedentary living, skill specialization, and year-round production of food - an in-place cycle of planting, tending, harvesting, and storage. ${ }^{36}$ A customary means of classifying GR-2 and GR-145 would be as residential and logistical campsites from early and late developmental phases in the hunter-gatherer seasonal round. But this Binford-esque explanation, with its inherent appeal to demographic or environmental limits, misses a critical element: the

\footnotetext{
${ }^{36}$ Agriculture is concerned with cropping domesticates; farming unites plants and animals in a food-production spectrum (Renfrew \& Bahn 2012). I have used the words somewhat interchangeably because of the presence of domesticated turkeys in cultural contexts during late prehistory in the northern Southwest (Schorger 1966, Williams, Jr., 1989).
} 
accumulation of social capital that occurs directly as a result of incremental population growth, cultural exchange, information transmittal, and gains in knowledge encoded as folkways, tool-systems, and oral history (Ingold in Gibson \& Ingold, eds., 1993, Vansina 1985).

There is nothing inevitable in this process. The gradual or catastrophic reversal of 'thin progress' has often occurred, thanks to bad weather, bad works, or bad luck. Nor am I suggesting one particular outcome over another, as though a spectral future is always lurking within the substantial present. The return to a foraging existence by Plains-Indian groups of the post-Cahokia diaspora, with highly sophisticated, if short lived, governances of the hunt, offers a prime example of why no one should view agriculture as exclusively synonymous with complex society (Hall 1997, Fletcher \& La Flesche 1992 [1911]). Rather, the formation of social capital lies at the heart of cultural processes carried out by every human group, as an aspect of species biology (North 2005). These processes are purposeful, time-aware, and accumulative, at least over certain periods. But they are in no sense coordinated or planned toward a single end (Hayek 1967) ${ }^{37}$ Thin progress explains neither too little nor too much. "Between place" analysis

There is one final issue to address. I have emphasized economic agency, skill development, and putative divisions of labor in my discussions of pre-adaptive processes for the late coming of agriculture in the Rio Chama Valley. But I have so far neglected to consider why agriculture was late to the region in the first place. There is no obvious answer

\footnotetext{
${ }^{37}$ An archaeologist thinking along similar lines is Kenneth Sassaman in The Eastern Archaic, Historicized (2010), but his idea of preliterate history sounds a lot like culture - and we already have a word for that. Ditto, Pauketat (2009). H. Martin Wobst is more ambiguous, oscillating between a big-data approach and unhelpful hosannas to shattered paradigms (in Sassaman \& Holly, Jr., eds., 2011). What we need is a common denominator for relating culture and history; I am suggesting that social capital might do the trick.
} 
to this question, outside the less-than-ideal conditions for farming - a shortcoming shared with many other locations in the high desert, which saw field-based cropping before the Piedra Lumbre Basin. Here I want to suggest, as a subject for future research, that the Rio Chama Valley's status as a between place made it valuable as a buffer zone for mediating the relations of several protohistoric cultures, and as a zone of cultural experimentation in the midst of more highly elaborated lifeways (following Anthony 2007 and Ortman 2012).

Resource collection at Ghost Ranch and other area locations was episodic from the start. In fact, there is little evidence for permanent structures of any kind until the Coalition Period pueblos (A.D. 1200-1325) - neither Prudden units nor pithouse villages, like Shabik'eschee and similar settlements on the San Juan Basin (Lekson, ed., 2006, Vivian 1990). Movement in and out of the region was also movement up and down mountainous terrain from river valleys and the vast ocean of grass to the east (Post in Vierra, ed., 2013, Vierra in Bousman \& Vierra, eds., 2012). Though encroachment on high-altitude hunting grounds by lowland farmers has been emphasized by Wills (1988, in Price \& Gebauer, eds., 1995), it is also likely that foragers came into contact with agriculturalists in the valleys and prairies at various times during the year. These interactions would have served as potential sources of knowledge for evaluating the feasibility of food production, of unifying scattered cultural spaces for efficiency's sake. ${ }^{38}$

As previously noted, Anasazi penetration of the Rio Chama Valley from anywhere on the San Juan Basin was minimal. Chaco was a resource sink, absorbing commodities and labor from around the region, and hardly shy about pursuing untapped wellsprings of value

\footnotetext{
${ }^{38}$ The lack of intermediate architectural forms is one reason for seeing the earliest pueblos as innovations, resulting from cultural negotiations between remnant foragers and emissary farmers, not unlike the late megalithic cultures of Neolithic Western Europe (Cunliffe 2008).
} 
(Lekson 1999, Lekson, ed., 2006, Sebastian 1992). This suggests that the Northern Rio Grande may have been politically useful as a no-man's land between the ritual chiefdom centered at Chaco and the horticultural and bison-hunting societies in the Rio Grande Valley and points east (Lakatos \& Wilson in Wilshusen, et al, eds., 2012). Once Chaco fell, the lack of deeply rooted settlements, with their attendant claims on resources and impositions of order, left the region open to the ethnogenesis events of the Classic Period (A.D. 1325-1600).

Two stand out. First was Tewa colonization of the Pajarito Plateau and adjacent locations, by descendent groups of the Mesa Verdean Anasazi. Scott Ortman argues that this might have occurred via demic diffusion, with small groups of pioneer risk-takers preceding larger population movements in the establishment of a simplified version of the home culture. He writes:

"[D]ue to the distance and isolation of pioneer settlements, the limited and irregular contact between homeland and frontier, the migrants are freed to modify elements of their homeland culture, adopt elements of local culture, or invent new elements as the local environment dictates" (2012:260).

This may help to explain the unexpected presence of experimental agriculture in the Rio Ojo Caliente Valley, as described by Buge (in S. Fish \& P. Fish, eds., 1984) and others (e.g., Ellis \& Dodge 1989).

A second ethnogenesis involved the Navajo or Diné, which also took place in the region, albeit a little to the west. According to Wilshusen, scholarly consensus is forming that Southern Athapaskan peoples, including the proto-Navajo, entered the northern Southwest around A.D. 1450, with the Navajo establishing a separate ethnic identity by A.D. 1650, prior to the Pueblo Revolt. The earliest Spanish mentions of the "Apaches del Nabaxu" place them in the Abiquiu area (Schaafsma 2002). Diné ethnohistories describe a coming together of the clans following the elimination of monsters from the surface world by the Hero Twins. Tribal 
construction appears to have been purposeful, with evidence for clan recruitment based on economic specializations: hunting, farming, pot-making, basket-weaving, and so on (Wilshusen in Scheiber \& Mitchell, eds., 2010).

As settlement and sedentary living came to the Northern Rio Grande, mobility was transformed from a lifeway regime to a mythological source of life. The old upland-lowland movements became an element of ethnic identity, recapitulated by the progress of clans into the world and across its sacred landscapes. Ian Hodder sees historical consciousness derived from family memory in the multigenerational burials of domestic structures at Çatal Höyük (2006). A similar argument can be made here, with movements in response to population pressure, ecological stress, political destabilization, and economic opportunity generating a sense of history in the novel living arrangements and ethnic assemblages of the Northern Rio Grande (Duwe \& Anschuetz in Vierra, ed., 2013). The "roads through time," or floating segments, of the Chacoan roadway system have been interpreted in a similar fashion (Earle 2001, Vivian 2001). “Ancestral Puebloans...used earthworks, site superposition, and 'roads through time' to construct social memory within outlier landscapes," writes Ruth Van Dyke (2007:192).

\section{Conclusion}

For more than 40 years, the volunteer crews of the Ghost Ranch Archaeology Seminar, serving under volunteer leaders, have sweated out sweltering weeks under the Zia sun, hoping to make some small connection with the vanished humanity of a stubbornly lovely landscape. Some days - typically after lunch before the monsoon blows in - the sites grow still and quiet, with nothing to hear but the gentle scrape of trowels on soil and the occasional hummingbird zipping by, attracted by the presence of red-tape flags. Suddenly 
you have the impression that people you cannot see, who are not really there, are nevertheless looking over your shoulder, remotely inspecting your work. This is my guess at what they could tell us - the crowded, ghostly silences of Ghost Ranch.

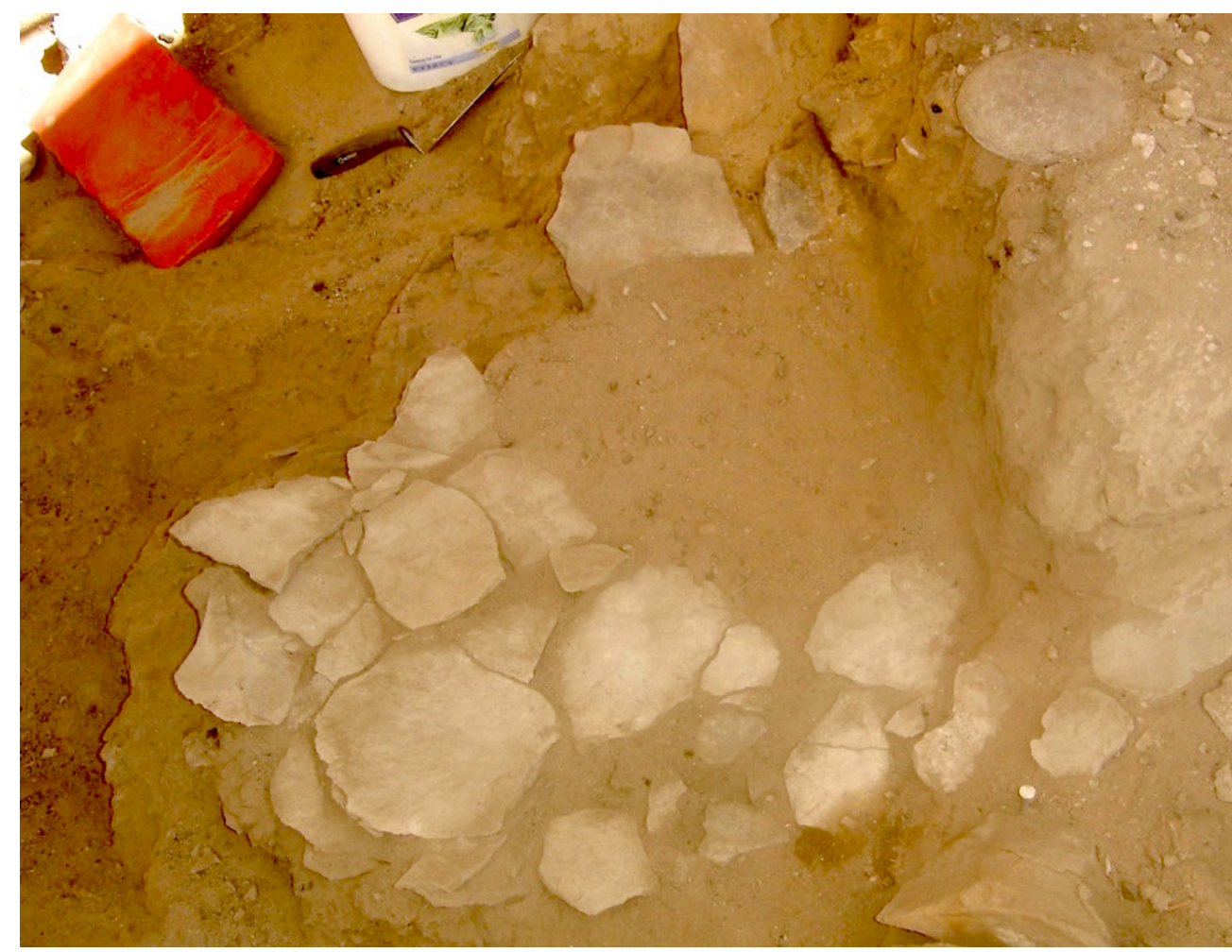

Figure 25. Remnants of a flagstone floor excavated by the author at GR-2. Pre-architectural elements of this kind were unusual during the Southwestern Archaic (Muceus, pers. comm.). Source: author photo. 


\section{REFERENCES}

\section{Primary Sources \& Ghost Ranch Archival Material}

Author unknown. "The Palisade Ruin (LA 3505): Archaeological Salvage Excavations Near the Abiquiu Dam, Rio Arriba County, New Mexico." Report to the Board of Christian Education, United Presbyterian Church, U.S.A. at Ghost Ranch, n.d.

Binggeli, Richard, et al. "Bull Canyon Campsite: 1,000 Years of History Under One Rock Shelter." In Artifacts, Shrines, and Pueblos: Papers in Honor of Gordon Page. Archaeological Society of New Mexico, n.d., pp. 41-8.

. "Archaeology at Ghost Ranch, 1971-2008." Apple Keynote presentation on GR-2. Personal communication by email. Sep. 7, 2009.

In-person interview. Audiocassette tape, Aug. 2, 2011.

Crews, Christopher. Background on Bull Canyon II. Personal communication, various dates. . "Fuel Choice in the Piedra Lumbre Valley: Charcoal Identification at the Bull Canyon II Site." Unpublished class paper for Paleoethnobotany, ANTH 637, Texas A\&M University, 2012.

Editorial Staff. Ghost Ranch Journal. Vol. 1, No. 3 (Fall 1986), Vol. 3, No. 2 (n.d.) \& Vol. 9, No. 1 (Winter 1994).

Ellis, Florence Hawley. "Highways to the Past." New Mexico Magazine, Vol. 53, No. 5, May 1975, pp. 18-25 \& 38-40.

Haecker, Charles M. "Archaeological Remote Sensing Survey of Two Jicarilla Apache Sites, LA 25309 and LA 138363, Ghost Ranch in Abiquiu, Rio Arriba County, New Mexico." Museums at Ghost Ranch, Occasional Papers, No. 1. Denver: Museums at Ghost Ranch and National Park Service, 2003.

Hayden, John. Site report: background information on GR-145 (dated Jul. 14, 2005).

Personal communication by email, Nov. 16, 2010.

. In-person interview. Audiocassette tape, Aug. 6, 2011.

Hoefer, David A., ed. Ghost Ranch Archaeological Bulletin (GRAB). Vol. 2, No. 4 (Spring 2007), Vol. 3, No. 1 (Summer 2008), Vol. 3, No. 2 (Summer 2009), Vol. 3, No. 3 (Summer 2010) \& Vol. 3, No. 4 (Summer 2011/2012).

Koning, D. J., et al. Preliminary Geologic Map of the Ghost Ranch Quadrangle, Rio Arriba County, New Mexico. Open-file Digital Geologic Map OF-GM 127. Socorro, N. Mex.: New Mexico Bureau of Geology and Mineral Resources, May 2006. 
McBride, Pamela J. "Plant Remains from an Archaic Rockshelter at the Ghost Ranch-2 Site [LA 13674], Abiquiu, New Mexico.” Report to the Ghost Ranch Archaeological Seminar, Nov. 1, 2008.

McFadden, Les. Background on site formation and geoscientific processes at GR-2. Personal communication, various dates.

Muceus, Cheryl. Background on GR-2 and GR-145. Personal communication, various dates.

Page, Gordon B. "East Pasture Rock Art." Unpublished mimeograph article for Ghost Ranch Archaeological Seminar, Jan. 1991.

Shibley, Jim, et al. "Bull Canyon Campsite: A Thousand Years of History Under One Rockshelter." Mimeograph article, n.d.

Wozniak, Frank J., et al. History and Ethnohistory Along the Rio Chama. Albuquerque, N. Mex.: United States Army Corps of Engineers, Albuquerque District, Sept. 1992.

Secondary Sources

Acklen, John C., ed. OLE, Volume III: Analysis. Albuquerque: TRC Mariah Associates, Public Service Company of New Mexico, 1997.

Adams, E. Charles \& Duff, Andrew I. The Protohistoric Pueblo World, AD 1275-1600. Tucson, Ariz.: University of Arizona Press, 2004.

Adler, Michael A., et al. "Ancestral Puebloan Population Aggregation and Abandonment in the North American Southwest." Journal of World Prehistory. Vol. 10, No. 3 (1996), pp. 375-438.

Agogino, George \& Hibben, Frank C. "Central New Mexico Paleo-Indian Cultures." American Antiquity. Vol. 23, No. 4 (Apr. 1958), pp. 422-25.

Airhart, Tom. Elk Hunting Guide: Skills, Gear, and Insight (2 ${ }^{\text {nd }}$ ed.). Mechanicsburg, Penn.: Stackpole Books, 2012.

Allen, Barry. Artifice and Design: Art and Technology in Human Experience. Ithaca, N.Y. \& London: Cornell University Press, 2008.

Altieri, Miguel A. Agroecology: The Science of Sustainable Agriculture ( $2^{\text {nd }}$ ed.). Boulder, Colo.: Westview Press, 1995.

Alvard, Michael S. "The Adaptive Nature of Culture." Evolutionary Anthropology. Vol. 12 (2003), pp. 136-49.

Anderson, Edgar. Plants, Man, and Life. Boston: Little, Brown, and Company, 1952.

Anschuetz, Kurt F. \& Merlan, Thomas. More Than a Scenic Landscape: Valles Caldera National Preserve Land Use History. General Technical Report RMRS-GTR-196. Fort Collins, Colo.: US Department of Agriculture, Forest Service, Rocky Mountain Research Station, Sept. 2007.

Antevs, Ernst. "Geologic-Climatic Dating in the West." American Antiquity. Vol. 20, No. 4 (Apr. 1955), pp. 317-35. 
Anthony, David W. The Horse, the Wheel, and Language: How Bronze-Age Rider from the Eurasian Steppes Shaped the Modern World. Princeton, N.J.: Princeton University Press, 2007.

Arber, Agnes. The Gramineae: A Study of Cereal, Bamboo, and Grass. Weinheim, Germany: J. Cramer, 1965.

Ashmore, Wendy \& Sharer, Robert J. Discovering Our Past: A Brief Introduction to Archaeology (6 ${ }^{\text {th }}$ ed.). New York: McGraw-Hill, 2014.

Baars, Donald L. The Colorado Plateau: A Geologic History. Albuquerque: University of New Mexico Press, 2000.

Bailey, Robert G. Description of the Ecoregions of the United States. U.S. Department of Agriculture, Miscellaneous Publication No. 1391, 1980.

Bailey, Vernon. Mammals of New Mexico. U.S. Department of Agriculture, Bureau of Biological Survey. North American Fauna, No. 53. Washington, D.C.: U.S. Government Printing Office, 1931.

Banning, E. B. The Archaeologist's Laboratory: The Analysis of Archaeological Data. Interdisciplinary Contributions to Archaeology. New York: Springer Science+Business Media, LLC, 2000.

Barlow, K. Renee. "Predicting Maize Agriculture Among the Fremont: An Economic Comparison of Farming and Foraging in the American Southwest." American Antiquity. Vol. 67, No. 1 (Jan. 2002), pp. 65-88.

Bartram, William. Ed. Gregory A. Waselkov \& Kathryn E. Holland Braund. William Bartram on the Southeastern Indians. Lincoln \& London: University of Nebraska Press, 1995.

Beaglehole, Ernest \& Sapir, Edward. Hopi Hunting and Hunting Ritual. Yale University Publications in Anthropology, No. 4. New Haven, Conn.: Yale University Press, 1936.

Beal, J.D. Foundations of the Rio Grande Classic: The Lower Chama River A.D. 1300-1500. Santa Fe: Southwest Archaeological Consultants, 1987.

Behrensmeyer, Anna K. "Taphonomic and Ecologic Information from Bone Weathering." Paleobiology. Vol. 4, No. (Spring 1978), pp. 150-62.

Beisaw, April M. Identifying and Interpreting Animal Bones: A Manual. College Station, Tex.: Texas A\&M University, 2013.

Berggren, Åsa \& Hodder, Ian. "Social Practice, Method, and Some Problems of Field Archaeology." American Antiquity. Vol. 68, No. 3 (Jul. 2003), pp. 421-34.

Bernardini, Wesley. "Transitions in Social Organization: A Predictive Model from Southwestern Archaeology." Journal of Anthropological Archaeology, Vol. 15 (1996), pp. 372-402.

Binford, Lewis R. "A Consideration of Archaeological Research Design.” American Antiquity. Vol. 29, No. 4 (Apr. 1964), pp. 425-41. 
Black, Stephen L. \& Jolly, Kevin. Archaeology by Design. Archaeologist's Toolkit, Volume 1. Walnut Creek, Calif.: AltaMira Press, 2003.

Blakey, Ron \& Ranney, Wayne. Ancient Landscapes of the Colorado Plateau. Grand Canyon, Ariz.: Grand Canyon Association, 2008.

Blitz, John H. "Adoption of the Bow in Prehistoric North America." North American Archaeologist. Vol. 9, No. 2 (1988), pp. 123-45.

Bohrer, Vorsila L., et al. "Carbonized Plant Remains from Two Hohokam Sites, Arizona BB:13:41 and Arizona BB:13:50.” Kiva. Vol. 35, No. 1 (Oct., 1969), pp. 1-10.

Bökönyi, S. "A New Method for the Determination of the Number of Individuals in Animal Bone Material.” American Journal of Archaeology. Vol. 74, No. 3 (Jul. 1970), pp. 291-2.

Bousman, C. Britt \& Vierra, Bradley J., eds. From the Pleistocene to the Holocene: Human Organization and Cultural Transformations in Prehistoric North America. College Station, Tex.: Texas A\&M University, 2012.

Brothwell, D.R. Digging Up Bones: The Excavation, Treatment, and Study of Human Skeletal Remains (3 ${ }^{\text {rd }}$ ed.). Ithaca, N.Y.: Cornell University Press, 1981.

Brown, David E., ed. Biotic Communities: Southwestern United States and Northwestern New Mexico. Salt Lake City: University of Utah Press, 1994.

Bryan, Kirk. "Flood-water Farming." Geographical Review. Vol. 19, No. 3 (Jul. 1929), pp. 444-56.

Buskirk, Winfred. The Western Apache: Living with the Land Before 1950. Norman, Okla. \& London: University of Oklahoma Press, 1986.

Calhoun, John B. \& Casby, James U. Calculation of Home Range and Density of Small Mammals. U.S. Dept. of Health, Education, \& Welfare. Public Health Monograph No. 55. Washington, D.C.: U.S. Government Printing Office, 1958.

Cameron, Catherine M. \& Duff, Andrew. "History and Process in Village Formation: Context and Contrasts from the Northern Southwest." American Antiquity, Vol. 73, No. 1 (2008), pp. 29-58.

Carter, George F. Plant Geography and Culture History in the American Southwest. Viking Fund Publications in Anthropology, No. 5. New York: Johnson Reprint Corporation, 1945.

Casteel, R. W. "Characterization of Faunal Assemblages and the Minimum Number of Individuals Determined from Paired Elements: Continuing Problems in Archaeology." Journal of Archaeological Science. Vol. 4 (1977), pp. 125-34.

Castetter, Edward F. Uncultivated Native Plants Used as Sources of Food. The University of New Mexico Bulletin. Ethnobiological Studies in the American Southwest. Vol. 4, No. 1 (May 15, 1935).

Clason, A.T., ed. Archaeozoological Studies: Papers of the Archaeozoological Conference 1974, Held at Biologisch-Archaeologisch Institut of the State University of Groningen. Amsterdam: North-Holland Publishing Company, 1975. 
Cochran, Gregory \& Harpending, Henry. The 10,000 Year Explosion: How Civilization Accelerated Human Evolution. New York: Basic Books, 2009.

Condie, Carol J. \& Fowler, Don D. Anthropology of the Desert West: Essays in Honor of Jesse D. Jennings. University of Utah Anthropological Papers, No. 110. Salt Lake City: University of Utah Press, 1986.

Cordell, Linda \& Gumerman, George J., eds. Dynamics of Southwest Prehistory. Washington, D.C.: Smithsonian Institution Press, 1989. 1997. Archaeology of the Southwest ( $2^{\text {nd }}$ ed.). San Diego, California: Academic Press,

, et al. "Archaeological Corn from Pueblo Bonito, Chaco Canyon, New Mexico: Dates, Contexts, Sources.” American Antiquity. Vol. 73, No. 3 (Jul. 2008), pp. 491511.

Cornwall, I.W. Bones for the Archaeologist (rev. ed.) London: J.M. Dent \& Sons, Ltd., 1974.

Crawford, Daniel J. "Systematic Relationships in the Narrow-Leaved Species of Chenopodium of the Western United States." Brittonia. Vol. 27, No. 3 (Jul.-Sep. 1975), pp. 279-88.

Cronk, Lee. That Complex Whole: Culture and the Evolution of Human Behavior. Boulder, Colo.: Westview Press, 1999.

Crown, Patricia L. \& Judge, James W., eds. Chaco \& Hohokam: Prehistoric Regional Systems in the American Southwest. School of American Research Advanced Seminar Series. Santa Fe, New Mexico: School of American Research Press, 1991.

Cunliffe, Barry. Europe Between the Oceans: 9000 BC-AD 1000. New Haven, Conn. \& London: Yale University Press, 2008.

Curtis, Gregory. The Cave Painters: Probing the Mysteries of the World's First Artists. New York: Anchor Books, 2006.

Cushing, Frank Hamilton. Ed. Jesse Green. Zuñi: Selected Writings of Frank Hamilton Cushing. Lincoln and London: University of Nebraska Press, 1979.

Davey, Christopher A. et al. Weather and Climate Inventory, National Park Service, Southern Colorado Plateau Network. National Technical Report NPS/SCPN/NRTR 2006/007. National Park Service, U.S. Department of the Interior. Fort Collins, Colo.: Natural Resource Program Center, Sept. 2006.

Davis, Simon J. M. The Archaeology of Animals. New Haven and London: Yale University Press, 1987.

Dawkins, Richard. The Selfish Gene (2 ${ }^{\text {nd }}$ ed.). Oxford: Oxford University Press, 1989.

Dean, Jeffrey S., et al. "Human Behavior, Demography, and Paleoenvironment on the Colorado Plateaus." American Antiquity. Vol. 50, No. 3 (1985), pp. 537-54.

Dean, Rebecca M., ed. The Archaeology of Anthropogenic Environments. Center for Archaeological Investigations, Occasional Paper No. 37. Carbondale, Ill.: Southern Illinois University, 2010. 
Degenhardt, William G., et al. Amphibians and Reptiles of New Mexico. Albuquerque: University of New Mexico Press, 1996.

Derbyshire, John. Unknown Quantity: A Real and Imaginary History of Algebra. Washington, D.C.: Joseph Henry Press, 2006.

Dice, Lee R. The Biotic Provinces of North America. Ann Arbor, Mich.: University of Michigan Press, 1943.

Dick, Herbert. Bat Cave. Monograph No. 27. Santa Fe: School of American Research, 1965.

Dick-Peddie, William A. New Mexico Vegetation: Past, Present, and Future. Albuquerque: University of New Mexico Press, 1993.

Dincauze, Dena. Environmental Archaeology: Principles and Practice. Cambridge: Cambridge University Press, 2000.

Doolittle, William E. Cultivated Landscapes of North America. Oxford Geographical and Environmental Studies. Oxford: Oxford University Press, 2000.

Douglas, John E. "Autonomy and Regional Systems in the Late Prehistoric Southern Southwest.” American Antiquity, Vol. 60, No. 2 (1995), pp. 240-257.

Doyel, David E., ed. Anasazi Regional Organization and the Chaco System. Maxwell Museum of Anthropology Anthropological Papers No. 5. Albuquerque: Maxwell Museum of Anthropology/University of New Mexico, 1992.

\& Dean, Jeffrey S., eds. Environmental Change and Human Adaptation in the Ancient American Southwest. Salt Lake City: University of Utah Press, 2006.

Drennan, Robert B. Statistics for Archaeologists: A Commonsense Approach. Interdisciplinary Contributions to Archaeology. New York: Kluwer Academic/Plenum Press, 1996.

Drewett, Peter. Field Archaeology: An Introduction (2 ${ }^{\text {nd }}$ ed.). London \& New York: Routledge, 2011.

Dunmire, William W. \& Tierney, Gail D. Wild Plants of the Pueblo Province: Exploring Ancient and Enduring Uses. Santa Fe: University of New Mexico Press, 1995.

Durand, Kathy Roler. "Function of Chaco-Era Great Houses." Kiva, Vol. 69, No. 2 (2003), pp. 141-169.

Dutton, Bertha P. American Indians of the Southwest. Albuquerque: University of New Mexico Press, 1983.

Earle, Timothy. How Chiefs Come to Power: The Political Economy in Prehistory. Stanford, California: Stanford University Press, 1997.

"Economic Support of Chaco Canyon Society." American Antiquity, Vol. 66, No. 1 (2001), pp. 26-35.

Elbroch, Mark. Animal Skulls: A Guide to North American Species. Mechanicsburg, Pa.: Stackpole Books, 2006.

Ellis, Florence Hawley. From Drought to Drought: Gallina Culture Patterns, Vol. 1.: Canjilon Mountain Hunting and Gathering Sites. Santa Fe: Sunstone Press, 1988. 
- \& Dodge, Andrea Ellis. “The Spread of Chaco/Mesa Verde/McElmo Black-onWhite Pottery and the Possible Simultaneous Introduction of Irrigation into the Rio Grande Drainage." Journal of Anthropological Research. Vol. 45, No. 1 (Spring 1989), pp. 47-52.

Ericson, Jonathon E. \& Baugh, Timothy G., eds. The American Southwest and Mesoamerica: Systems of Prehistoric Exchange. New York and London: Plenum Press, 1993.

Euler, Robert C., et al. "The Colorado Plateaus: Cultural Dynamics and Paleoenvironment." Science. New Series, Vol. 205, No. 4411 (Sep. 14, 1979), pp. 1,089-101.

Fagan, Brian M. Ancient North America: The Archaeology of a Continent ( $4^{\text {th }} \mathrm{ed}$.). New York: Thames \& Hudson, 2005.

Fanning, Delvin S. \& Fanning, Mary C. B. Soil: Morphology, Genesis, and Classification. New York: John Wiley \& Sons, 1989.

Fewkes, J. Walter. The Mimbres: Art and Archaeology. Albuquerque: Avanyu Publishing, Inc., 1989.

Findley, James S. The Natural History of New Mexican Mammals. New Mexico Natural History Series. Albuquerque: University of New Mexico Press, 1987.

Fish, Paul R. \& Reid, J. Jefferson, eds. Interpreting Southwestern Diversity: Underlying Principles and Overarching Patterns. Anthropological Research Papers No. 48. Tempe, Ariz.: Arizona State University, 1996.

Fish, Suzanne K. \& Fish, Paul R., eds. Prehistoric Agricultural Strategies in the Southwest. Anthropological Research Papers, No. 33. Tempe, Ariz.: Arizona State University, 1984.

\& Fish, Paul R. "Prehistoric Desert Farmers of the Southwest." Annual Review of Anthropology. Vol. 23 (1994), pp. 83-108.

Flannery, Kent, ed. Guilá Naquitz: Archaic Foraging and Early Agriculture in Oaxaca, Mexico. Orlando, Fla.: Academic Press, 1986.

Fletcher, Alice C. \& La Flesche, Francis. The Omaha Tribe (Vol. 1). Lincoln, Neb.: Bison Books, 1992 (rpt. 1911 ed.).

Fletcher, Mike \& Lock, Gary R. Digging Numbers: Elementary Statistics for Archaeologists ( $2^{\text {nd }}$ ed.). Monograph 33. Oxford: Oxford School of Archaeology, 2005.

Ford, Richard I. "Gathering and Farming Before AD 1000: Patterns of Prehistoric Cultivation North of Mexico.” Journal of Ethnobiology. Vol. 1, No. 1 (1981), pp. 6-27.

--------------, ed. An Ethnology Source Book: The Uses of Plants and Animals by American Indians. The North American Indian Series. New York \& London: Garland Publishing, Inc., 1986.

Fritz, Gayle J. "Identification of Cultigen Amaranth and Chenopod from Rockshelter Sites in Northwest Arkansas." American Antiquity. Vol. 49, No. 3 (Jul., 1984), pp. 558-72. . "New Dates and Data on Early Agriculture: The Legacy of Complex HunterGatherers." Annals of the Missouri Botanical Garden. Vol. 82, No. 1 (1995), pp. 315. 
Frost, Max \& Walter, Paul A. F., eds. The Land of Sunshine: A Handbook of the Resources, Products, Industries, and Climate of New Mexico. James S. Duncan, Printer, 1904.

Fry, Gary \& Hall, H. J. "Human Coprolites from Antelope House: Preliminary Analysis." Kiva. Vol. 41, No. 1 (Fall 1975), pp. 87-96.

Fuller, Dorian Q., et al. "Domestication as Innovation: The Entanglement of Techniques, Technology, and Chance in the Domestication of Cereal Crops." World Archaeology. Vol. 41, No. 1 (2010), pp. 13-28.

Fussell, Betty. The Story of Corn: The Myths and History, the Culture and Agriculture, the Art and Science of America's Quintessential Crop. New York: Alfred A. Knopf, 1992.

Gabin, V. and Lesperance, L.L. New Mexico Climatological Data: Precipitation, Temperature, Evaporation and Wind, Monthly and Annual Means, 1850-1975. Socorro, N. Mex.: W.K. Summers, 1977.

Geertz, Clifford. The Interpretation of Cultures: Selected Essays. New York: Basic Books, 1973.

Gibson, Kathleen R. \& Ingold, Tim, eds. Tools, Language and Cognition in Human Evolution. Cambridge: Cambridge University Press, 1993.

Gilbert, B. Miles. Mammalian Osteology. Columbia, Mo.: Missouri Archaeological Society, 1990.

Gilman, Patricia A. Wandering Villagers: Pit Structures, Mobility and Agriculture in Southeastern Arizona. Anthropological Research Papers No. 49. Tempe, Ariz.: Arizona State University, 1997.

Glassow, Michael A. Prehistoric Agricultural Development in the Northern Southwest: A Study in Changing Patterns of Land Use. Ballena Press Anthropological Papers, No. 16. Socorro, N. Mex.: Ballena Press, 1980.

Gordon, C.C. \& Buikstra, J.E. "Soil, pH, Bone Preservation, and Sampling Bias at Mortuary Sites.” American Antiquity. Vol. 46, No. 3, (1981), pp. 566-71.

Gould, Stephen Jay \& Vrba, Elizabeth S. "Exaptation - A Missing Term in the Science of Form.” Paleobiology. Vol. 8, No. 1 (Winter 1982), pp. 4-15.

Grayson, Donald K. Quantitative Zooarchaeology: Topics in the Analysis of Archaeological Faunas. Studies in Archaeological Science. Orlando: Academic Press, Inc., 1984.

Gregg, Joseph. Ed. Max L. Moorhead. Commerce of the Prairies. Norman, Okla.: University of Oklahoma Press, 1974 (rpt. 1844 ed.).

Gremillion, Kristen J. "Crop and Weed in Prehistoric Eastern North America: The Chenopodium Example.” American Antiquity. Vol. 58, No. 3 (Jul. 1993), pp. 496509.

ed. People, Plants, and Landscapes: Studies in Paleoethnobotany. Tuscaloosa \& London: University of Alabama Press, 1997.

Gudeman, Stephen. The Anthropology of Economy: Community, Market, and Culture. Malden, Mass.: Blackwell Publishing, 2001. 
Gumerman, George J. Themes in Southwest Prehistory. School of American Research Advanced Seminar Series. Santa Fe: School of American Research Press, 1994.

Gwartney, James D. \& Stroup, Richard L. Microeconomics: Private and Public Choice ( $8^{\text {th }}$ ed.). Fort Worth, Tex.: The Dryden Press, 1997.

Hagstrum, Melissa. "Household Production in Chaco Canyon Society." American Antiquity, Vol. 66, No. 1 (2001), pp. 47-55.

Hall, E. Raymond. The Mammals of North America, Volume II ( $2^{\text {nd }}$ ed.). New York: John Wiley \& Sons, 1981.

Hall, Robert L. An Archaeology of the Soul: North American Indian Belief and Ritual. Urbana, Ill. \& Chicago: University of Illinois Press, 1997.

Hall, Stephen A. "Early Maize Pollen from Chaco Canyon, New Mexico, USA." Palynology. Vol. 34, No. 1 (2010), pp. 125-37.

Hayek, Friedrich. Studies in Philosophy, Politics, and Economics. New York: Simon and Schuster, 1967.

Haynes, Gary. “A Guide for Differentiating Mammalian Carnivore Taxa Responsible for Gnaw Damage to Herbivore Limb Bones.” Paleobiology. Vol. 9, No. 2 (Spring 1983), pp. 164-72.

Heffelfinger, Jim. Deer of the Southwest: A Complete Guide to the Natural History, Biology, and Management of Southwestern Mule Deer and White-tailed Deer. College Station, Tex.: Texas A\&M University Press, 2006.

Henderson, Junius \& Harrington, John Peabody. Ethnozoology of the Tewa Indians. Bureau of American Ethnology, Bulletin 56. Washington, D.C.: Government Printing Office, 1914.

Henrich, Joseph \& McElreath, Richard. "The Evolution of Cultural Evolution." Evolutionary Anthropology. Vol. 12 (2003), pp. 123-35.

Herskovits, Melville J. Economic Anthropology: The Economic Life of Primitive Peoples. New York: W.W. Norton \& Company, Inc., 1952.

Hesse, Brian \& Wapnish, Paula. Animal Bone Archeology: From Objectives to Analysis. Manuals on Archeology, No. 5. Washington, D. C.: Taraxacum, Inc., 1985.

Hewett, Edgar L. Antiquities of the Jemez Plateau, New Mexico. Bureau of American Ethnology, Bulletin 32. Washington, DC: Government Printing Office, 1906.

Hibben, Frank C. Excavation of the Riana Ruin and Chama Valley Survey. University of New Mexico Bulletin, Anthropological Series, Vol. 2, No. 1. Albuquerque: University of New Mexico Press, 1937.

Higgs, E.S., ed. Papers in Economic Prehistory: Studies by Members and Associates of the British Academy Major Research Project in the Early History of Agriculture. Cambridge: Cambridge University Press, 1972.

Hildebrandt, William R. \& McGuire, Kelly R. "The Ascendance of Hunting During the California Middle Archaic: An Evolutionary Perspective." American Antiquity. Vol. 67, No. 2 (Apr. 2002), pp. 231-56. 
Hill, Jane H. “Toward a Linguistic Prehistory of the Southwest: 'Aztec-Tanoan' and the Arrival of Maize Cultivation." Journal of Anthropological Research. Vol. 58, No. 4 (Winter 2002), pp. 457-75.

Hillson, Simon. Mammal Bones and Teeth: An Introductory Guide to Methods of Identification. London: Institute of Archaeology, 1992.

-------------. Teeth ( $2^{\text {nd }}$ ed.). Cambridge Manuals in Archaeology. Cambridge: Cambridge University Press, 2005.

Hocking, George M. "Some Plant Materials Used Medicinally and Otherwise by the Navaho Indians in the Chaco Canyon, New Mexico." El Palacio, Vol. 63, Nos. 5-6 (1956), pp. 146-65.

Hogan, Patrick. "Dinetah: A Reevaluation of Pre-revolt Navajo Occupation in Northwest New Mexico.” Journal of Anthropological Research. Vol. 45, No. 1 (Spring 1989), pp. 53-66.

Hodder, Ian, ed. Archaeology as Long-term History. New Directions in Archaeology. Cambridge: Cambridge University Press, 1987.

--------------. The Archaeological Process: An Introduction. Oxford: Blackwell Publishers Ltd., 1999.

----------. The Leopard's Tale: Revealing the Mysteries of Çatalhöyük. London: Thames \& Hudson, Ltd., 2006.

Hogan, Patrick \& Winter, Joseph C., eds. Economy and Interaction Along the Lower Chaco River: The Navajo Mine Archaeological Program, Mining Area III, San Juan County, New Mexico. Albuquerque: Office Contract Archaeology \& The Maxwell Museum of Anthropology, University of New Mexico. UNM Project \#185-94/94A, May 20, 1983.

Huckell, Bruce B. "The Archaic Prehistory of the North American Southwest." Journal of World Prehistory. Vol. 10, No. 3 (1996), pp. 305-73.

Ingold, Tim. The Perception of the Environment: Essays in Livelihood, Dwelling, and Skill. London \& New York: Routledge, 2000.

Irwin-Williams, Cynthia \& Haynes, C. Vance. "Climatic Change and Early Population Dynamics in the Southwestern United States." Quaternary Research. Vol. 1 (1970), pp. 59-71.

James, Steven R. "Methodological Issues Concerning Screen Size Recovery and Their Effects on Archaeofaunal Interpretations.” Journal of Archaeological Science. Vol. 24, Issue 5 (May 1997), pp. 385-97.

Jeancon, Jean Allard. "Ruins at Pesedeuinge." Records of the Past. Vol. 11, No. 1 (1912), pp. 28-37.

------------. Excavations in the Chama Valley, New Mexico. Bureau of American Ethnology, Bulletin 81. Washington, D.C.: Government Printing Office, 1923.

Jennings, Jesse D. \& Norbeck, Edward. “Great Basin Prehistory: A Review.” American Antiquity. Vol. 21, No. 1 (Jul. 1955), pp. 1-11. 
Jochim, Michael A. Strategies for Survival: Cultural Behavior in an Ecological Context. New York: Academic Press, 1981.

Johnson, Allen W. \& Earle, Timothy. The Evolution of Human Societies: From Foraging Group to Agrarian State (2 ${ }^{\text {nd }}$ ed.). Stanford, Cali.: Stanford University Press, 2000.

Johnson, Eileen \& Holliday, Vance T. "The Archaic Record at Lubbock Lake." Plains Anthropologist. Vol. 31, No. 114, Part 2 (1986), pp. 7-54.

Judd, Neil M. The Material Culture of Pueblo Bonito. Smithsonian Miscellaneous Collections, Vol. 124. Washington: Smithsonian Institution, 1954.

Kantner, John. "Political Competition among the Chaco Anasazi of the American Southwest." Journal of Anthropological Archaeology, Vol. 15 (1996), pp. 41-105.

----------. “Rethinking Chaco as a System.” Kiva, Vol. 69, No. 2 (2003), pp. 207-227.

-------------. Ancient Puebloan Southwest. Cambridge: Cambridge University Press, 2004.

Kaplan, Hillard S., et al. The Evolutionary and Ecological Roots of Human Social Organization." Philosophical Transactions of the Royal Society B, Vol. 364 (2009), pp. 3289-99.

Kelly, Robert L. The Foraging Spectrum: Diversity in Hunter-gatherer Lifeways. Clinton Corners, N.Y.: Percheron Press, 2007.

Kent, Susan, ed. Farmers as Hunters: The Implications of Sedentism. New Directions in Archaeology. Cambridge: Cambridge University Press, 1989.

. "Excavations at a Small Mesa Verde Pueblo II Anasazi Site in Southwestern Colorado.” Kiva. Vol. 57, No. 1 (1991), pp. 55-75.

Killion, Thomas W., ed. Gardens of Prehistory: The Archaeology of Settlement Agriculture in Greater Mesoamerica. Tuscaloosa, Ala. \& London: University of Alabama Press, 1992.

Klein, Richard \& Cruz-Uribe, Kathryn. The Analysis of Animal Bones from Archaeological Sites. Prehistoric Archaeology and Ecology Series. Chicago and London: The University of Chicago Press, 1984.

Kohler, T. A., et al. "The Neolithic Demographic Transition in the U. S. Southwest." American Antiquity. Vol. 73, No. 4 (2008), pp. 645-69.

, et al, eds. Leaving Mesa Verde: Peril and Change in the Thirteenth-century Southwest. Tucson, Ariz.: University of Arizona Press, 2010.

Koster, William J. Guide to the Fishes of New Mexico. Albuquerque: University of New Mexico Press, 1957.

Krieger, William Harvey. Can There Be a Philosophy of Archaeology? Processual Archaeology and the Philosophy of Science. Lanham, Md.: Lexington Books, 2006.

Kroeber, Theodora. Ishi in Two Worlds: A Biography of the Last Wild Indian in North America. Berkeley \& Los Angeles, Calif.: University of California Press, 1961. 
Lamb, J., Jr. \& Chapman, J.E. "Effects of Surface Stones on Erosion, Evaporation, Soil Temperature, and Soil Moisture." Journal of the American Society of Agronomy. Vol. 35 (1943), pp. 567-78.

Lambert, Joseph B. Traces of the Past: Unraveling the Secrets of Archaeology through Chemistry. Reading, Mass.: Perseus Books, 1997.

Lang, Richard W. \& Harris, Arthur H. The Faunal Remains from Arroyo Hondo Pueblo, New Mexico: A Study in Short-term Subsistence Change. Santa Fe, N. Mex.: School of American Research Press, 1984.

Laubin, Reginald \& Laubin, Gladys. American Indian Archery. Norman, Okla.: University of Oklahoma Press, 1980.

Lekson, Stephen H. \& Cameron, Catherine M. "The Abandonment of Chaco Canyon, the Mesa Verde Migrations, and the Reorganization of the Pueblo World." Journal of Anthropological Archaeology, Vol. 14 (1995), pp. 184-202.

-. The Chaco Meridian: Centers of Political Power in the Ancient Southwest. Walnut Creek, California: Altamira Press, 1999.

-----.-.' "War in the Southwest, War in the World." American Antiquity, Vol. 67, No. 4 (2002), pp. 607-24.

, ed. The Archaeology of Chaco Canyon: An Eleventh Century Pueblo Regional Center. School of American Research Advanced Seminar Series. Santa Fe, New Mexico: School of American Research Press, 2006.

Lent, Stephen C. Survey, Test Excavation Results, and Data Recovery Plan for Cultural Resources Near San Juan Pueblo, Rio Arriba County, New Mexico. Archaeology Notes 17. Santa Fe: Office of Archaeological Studies, Museum of New Mexico, 1991.

Leopold, Luna B. A View of the River. Cambridge, Mass.: Harvard University Press, 1994.

Lewis-Williams, David. The Mind in the Cave: Consciousness and the Origins of Art. London: Thames \& Hudson, 2002.

Lightfoot, Dale R. \& Eddy, Frank W. "The Construction and Configuration of Anasazi Pebble-mulch Gardens in the Northern Rio Grande." American Antiquity. Vol. 60, No. 3 (1995), pp. 459-70.

Linares, Olga F. "'Garden Hunting' in the American Tropics.” Human Ecology. Vol. 4, No. 4 (Oct. 1976), pp. 331-49.

Linton, Ralph, ed. Acculturation in Seven American Indian Tribes. New York: D. AppletonCentury Company, 1940.

Lister, Robert H. \& Lister, Florence C. Chaco Canyon. Albuquerque: University of New Mexico Press, 1981.

Lubinski, Patrick M. "The Communal Pronghorn Hunt: A Review of the Ethnographic and Archaeological Evidence." Journal of California and Great Basin Anthropology. Vol. 21, No. 2 (1999), pp. 158-81. 
Lucas, Spencer G., et al. "Upper Triassic Stratigraphy and Biostratigraphy, Chama Basin, North-Central New Mexico." Paleontology and Geology of the Snyder Quarry, New Mexico Museum of Natural History and Science Bulletin, No. 24 (2003), pp. 15-40.

Lyman, R. Lee. Vertebrate Taphonomy. Cambridge Manuals in Archaeology. Cambridge: Cambridge University Press, 1994.

------------. Quantitative Paleozoology. Cambridge Manuals in Archaeology. Cambridge: Cambridge University Press, 2008.

Mackey, James. "Vallecitos Pueblo (a Fourteenth Century AD Ancestral Jemez Site) and LA 12761 (a Late Prehistoric-Early Historic Jemez Phase Farm House).” Journal of Intermountain Archaeology. Vol. 1, No. 2 (1982), pp. 80-99.

Maker, H.J., et al. Soils of New Mexico. Agricultural Experiment Station, Research Report 285. Las Cruces, N. Mex.: New Mexico State University, 1978.

Martin, Steve L. "Virgin Anasazi Diet as Demonstrated through the Analysis of Stable Carbon and Nitrogen Isotopes." Kiva. Vol. 64, No. 4 (Summer 1999), pp. 495-515.

Mathien, Frances Joan \& McGuire, Randall H., eds. Ripples in the Chichimec Sea: New Considerations of Southwestern-Mesoamerican Interaction. Carbondale and Edwardsville: Southern Illinois University Press, 1986.

Culture and Ecology of Chaco Canyon and the San Juan Basin. Publications in Archeology 18H, Chaco Canyon Series. Santa Fe, New Mexico: National Park Service/U.S. Dept. of Interior, 2005.

Matson, R.G. The Origins of Southwestern Agriculture. Tucson \& London: University of Arizona Press, 1991.

Maxwell, Timothy D. Looking for Adaptation: A Comparative and Engineering Analysis of Prehistoric Agricultural Technologies and Techniques in the Southwest. Unpublished PhD diss. (posted online). Albuquerque: University of New Mexico, May 2000.

Mayr, Ernst. "How to Carry Out the Adaptationist Program?" The American Naturalist. Vol. 121, No. 3 (Mar. 1983), pp. 324-34.

Mera, H.P. A Survey of the Biscuit Ware Area in Northern New Mexico. Technical Series, Bulletin No. 6. Santa Fe: Laboratory of Anthropology, Inc., May 1934.

Miller, Gerrit S., Jr. \& Kellogg, Remington. List of North American Recent Mammals. United States National Museum Bulletin 205. Washington, D.C.: Smithsonian Institution, 1955.

Minnis, Paul E. "Prehistoric Diet in the Northern Southwest: Macroplant Remains from Four Corners Feces." American Antiquity. Vol. 54, No. 3 (Jul. 1989), pp. 543-63.

\& Redman, Charles L. Perspectives on Southwestern Prehistory. Investigations in American Archaeology. Boulder, Colo.: Westview Press, 1990.

\& Elisens, Wayne J., ed. Biodiversity and Native America. Norman, Okla.: University of Oklahoma Press, 2000. 
Mohler, Charles L. \& Callaway, M. Brett. "Effects of Tillage and Mulch on Weed Seed Production and Seed Banks in Sweet Corn.” Journal of Applied Ecology. Vol. 32, No. 3 (Aug. 1995), pp. 627-39.

Monod, Jacques. Trans. Austryn Wainhouse. Chance and Necessity: An Essay on the Natural Philosophy of Modern Biology. New York: Vintage Books, 1972.

Moore, James L. \& Winter, Joseph C., eds. Human Adaptations in a Marginal Environment: The UII Mitigation Project: Archaeological Report of the Mitigation of Eight Archaeological Sites in Mining Area III of the Utah International, Inc., on Navajo Reservation Land. Albuquerque: Office of Contract Archaeology, 1980.

ed. Archaeological Testing at Three Sites West of Abiquiu, Rio Arriba County, New Mexico. Archaeology Notes 33. Santa Fe: Office of Archaeological Studies, Museum of New Mexico, 1992.

, et al, eds. Adaptations on the Anasazi and Spanish Frontiers: Excavations at Five Sites Near Abiquiu, Rio Arriba County, New Mexico. Archaeology Notes 187. Santa Fe: Office of Archaeological Studies, Museum of New Mexico, 2004.

Moore, Michael. Medicinal Plants of the Mountain West (rev. ed.). Santa Fe: Museum of New Mexico Press, 2003.

Morris, W. Scott \& Haggard, Keith W. New Mexico Climate Manual: Solar and Weather Data. New Mexico Energy Research and Development Institute. Report No. 72-4523, November 1985.

Neitzel, Jill E., ed. Pueblo Bonito: Center of the Chacoan World. Washington and London: Smithsonian Books, 2003.

Noble, David Grant, ed. In Search of Chaco: New Approaches to an Archaeological Enigma. Santa Fe, New Mexico: School of American Research Press, 2004.

ed. The Mesa Verde World: Explorations in Ancestral Puebloan Archaeology. Santa Fe: School of American Research Press, 2006.

Noe-Nygaard, Nanna. "Butchering and Marrow Fracturing as a Taphonomic Factor in Archaeological Deposits.” Paleobiology. Vol. 3, No. 2 (Spring 1977), pp. 218-37.

Nordenskiöld, Gustaf. Trans. D. Lloyd Morgan. The Cliff Dwellers of the Mesa Verde: Southwestern Colorado: Their Pottery and Implements. Glorieta, N. M.: The Rio Grande Press, Inc., 1979 (rpt. 1893 ed.).

North, Douglass C. Understanding the Process of Economic Change. Princeton, N.J.: Princeton University Press, 2005.

O’Connor, Terry. The Archaeology of Animal Bones. College Station, Tex.: Texas A\&M University Press, 2000.

Olsen, Stanley J. Mammal Remains from Archaeological Sites: Part 1, Southeastern and Southwestern United States. Papers of the Peabody Museum of Anthropology and Ethnology, Vol. 56, No. 1. Cambridge, Mass.: Harvard University Press, 1964. 
Fish, Amphibian and Reptile Remains from Archaeological Sites. Part 1, Southeastern and Southwestern United States \& The Osteology of the Wild Turkey. Papers of the Peabody Museum of Anthropology and Ethnology, Vol. 56, No. 2. Cambridge, Mass.: Harvard University Press, 1968.

\& Wheeler, Richard Page. Bones from Awatovi: Northeastern Arizona. Papers of the Peabody Museum of Anthropology and Ethnology, Vol. 70, Nos. $1 \& 2$. Cambridge, Mass.: Harvard University Press, 1978.

- Osteology for Archaeologists. Papers of the Peabody Museum of Anthropology and Ethnology, Vol. 56, Nos. 3, 4 \& 5. Cambridge, Mass.: Harvard University Press, 1979.

Ortiz, Alfonso, ed. Handbook of the North American Indians, Volume 9: Southwest. Washington: Smithsonian Institution, 1979.

Ortman, Scott G. Winds from the North: Tewa Origins and Historical Anthropology. Salt Lake City, Utah: University of Utah Press, 2012.

Osborn, Alan J. "Snowblind in the Desert: Moisture Islands, Ungulate Ecology, and Alternative Prehistoric Overwintering Strategies." Journal of Anthropological Research. Vol. 49, No. 2 (Summer 1993), pp. 135-64.

Pack, Arthur Newton. ...We Called It Ghost Ranch. Abiquiu, N. Mex.: Ghost Ranch Conference Center, 1979.

Page, Lawrence M. \& Burr, Brooks M. Freshwater Fishes. Peterson Field Guides. Boston \& New York: Houghton Mifflin Company, 1991.

Pauketat, Timothy R. Cahokia: Ancient America's Great City on the Mississippi. The Penguin Library of American Indian History. New York: Viking, 2009.

Pepper, George H. Pueblo Bonito. Albuquerque: University of New Mexico Press, 1920 (rpt. 1996 ed.).

Periman, Richard D. “Modeling Landscapes and Past Vegetation Patterns of New Mexico’s Rio Del Oso Valley.” Geoarchaeology. Vol. 20, No. 2, pp. 193-210.

Plog, Fred \& Wait, Walter, eds. The San Juan Tomorrow: Planning for Conservation of Cultural Resources in the San Juan Basin. Santa Fe: National Park Service, Southwest Region, in cooperation with School of American Research, 1982.

Plog, Stephen. Ancient Peoples of the American Southwest. London: Thames \& Hudson, 2007.

Plug, Cornelius \& Plug, Ina. "MNI Counts as Estimates of Species Abundance." South African Archaeological Bulletin. Vol. 45, (1990), pp. 53-7.

Poling-Kempes, Leslie. Valley of Shining Stone: The Story of Abiquiu. Tucson, Ariz.: University of Arizona Press, 1997. Ghost Ranch. Tucson, Ariz.: University of Arizona Press, 2005.

Pope, Saxton. Hunting with the Bow and Arrow. Charleston, S. C.: BiblioBazaar, Aug. 4, 2010 (on-demand rpt.). 
Powers, Robert P., ed. The Peopling of Bandelier: New Insights from the Archaeology of the Pajarito Plateau. Santa Fe: School of American Research Press, 2005.

Prance, Ghillean \& Nesbitt, Mark, eds. The Cultural History of Plants. New York \& London: Routledge, 2005.

Price, L. Greer. The Geology of Northern New Mexico's Parks, Monuments, and Public Lands. New Mexico Bureau of Geology and Mineral Resources. Socorro, N. Mex.: 2010.

Price, T. Douglas \& Gebauer, Anne Birgitte, eds. Last Hunters-First Farmers: New Perspectives on the Prehistoric Transition to Agriculture. School of American Research Advanced Seminar Series. Santa Fe: School of American Research Press, 1995.

Rackham, James. Animal Bones. Interpreting the Past series. Berkeley, Calif.: The University of California Press/British Museum, 1994.

Raloff, Janet. “Corn's Slow Path to Stardom.” Science News. Vol. 143, No. 16 (Apr. 17, 1993), pp. 248-50.

Ramenofsky, Ann F. \& Feathers, James K. "Documents, Ceramics, Tree Rings, and Luminescence: Estimating Final Native Abandonment of the Lower Rio Chama." Journal of Anthropological Research. Vol. 58, No. 1 (Spring 2002), pp. 121-59.

Rebolledo, Tey Diana \& Márquez, María Teresa, eds. Women's Tales from the New Mexico WPA: La Diabla a Pie. Houston: Arte Pública Press, 2000.

Redman, Charles L., et al, eds. The Archaeology of Global Change: The Impact of Humans on Their Environment. Washington, D.C.: Smithsonian Books, 2004.

Reed, Lori Stephens \& Reed, Paul F., eds. Cultural Diversity \& Adaptation: The Archaic, Anasazi, \& Navajo Occupation of the Upper San Juan Basin. Cultural Resources Series, No. 9. Santa Fe: Bureau of Land Management, New Mexico State Office, 1992.

Rehder, Harald A. National Audubon Society Field Guide to North American Seashells. New York: Alfred A. Knopf, 1981.

Reher, Charles A., ed. Settlement and Subsistence Along the Lower Chaco River: The GCP Survey. Albuquerque: University of New Mexico Press, 1977.

Reichard, Gladys A. Navaho Religion: A Study of Symbolism. Bollingen Series XVIII. Princeton, N.J.: Princeton University Press, 1950.

Reitz, Elizabeth J. \& Wing, Elizabeth S. Zooarchaeology. Cambridge Manuals in Archaeology. Cambridge: Cambridge University Press, 1999.

Reed, Alan D. \& Horn, Jonathon C. "Early Navajo Occupation of the American Southwest: Reexamination of the Dinetah Phase." The Kiva. Vol. 55, No. 4 (1990), pp. 283-300.

Renfrew, Colin. "Production and Consumption in a Sacred Economy: The Material Correlates of High Devotional Expression at Chaco Canyon." American Antiquity, Vol. 66, No. 1 (2001), pp. 14-25. 
-- \& Bahn, Paul. Archaeology: Theories, Methods, and Practice $\left(6^{\text {th }}\right.$ ed.). New York: Thames \& Hudson, 2012.

Richerson, Peter J. \& Boyd, Robert. Not by Genes Alone: How Culture Transformed Human Evolution. Chicago: University of Chicago Press, 2005.

Riley, Carroll L. \& Hedrick, Basil C., eds. Across the Chichimec Sea: Papers in Honor of J. Charles Kelley. Carbondale and Edwardsville: Southern Illinois University Press, 1978.

Rio del Norte: People of the Upper Rio Grande From Earliest Times to the Pueblo Revolt. Salt Lake City: University of Utah Press, 1995.

Rindos, David. The Origins of Agriculture: An Evolutionary Perspective. Orlando: Academic Press, 1984.

Roberts, Neil. The Holocene: An Environmental History. Oxford: Blackwell Publishing, 1998.

Rose, Carolyn June. Quantitative Analyses of Plant Remains from the Nan Ranch Ruin, Grant County, New Mexico. Unpublished M.A. thesis (posted online). College Station, Tex.: Texas A\&M University, Aug. 2004.

Rose, Martin R., et al. The Past Climate of Arroyo Hondo New Mexico Reconstructed from Tree Rings. Santa Fe, N. Mex.: School of American Research Press, 1981.

Rostlund, Erhard. Freshwater Fish and Fishing in Native North America. University of California Publications in Geography, Vol. 9. Berkeley and Los Angeles: University of California Press, 1952.

Roth, Barbara J., ed. Early Formative Adaptations in the Southern Southwest. Monographs in New World Archaeology No. 25. Madison, Wis.: Prehistory Press, 1996.

" "The Role of Gender in the Adoption of Agriculture in the Southern

Southwest." Journal of Anthropological Research. Vol. 62, No. 4 (Winter 2006), pp. 513-38.

Saitta, Dean J. "Power, Labor, and the Dynamics of Change in Chacoan Political Economy." American Antiquity, Vol. 62, No. 1 (1997), pp. 7-26.

Sassaman, Kenneth E. The Eastern Archaic, Historicized. Lanham, Md.: AltaMira Press, 2010.

\& Holly, Donald H., Jr., eds. Hunter-gatherer Archaeology as Historical Process. Tucson, Ariz.: University of Arizona Press, 2011.

Schaafsma, Curtis F. Archaeological Studies in the Abiquiu Reservoir District. United States Army Corps of Engineers, n.d. (rpt., School of American Research, 1978).

-------------. Apaches de Navajo: Seventeenth-century Navajos in the Chama Valley of New Mexico. Salt Lake City: University of Utah Press, 2002.

Schaafsma, Polly. Warrior, Shield, and Star: Imagery and Ideology of Pueblo Warfare. Santa Fe, N. Mex.: Western Edge Press, 2000. 
Scheiber, Laura L. \& Mitchell, Mark D., eds. Across a Great Divide: Continuity and Change in Native North American Societies, 1400-1900. Tucson, Ariz.: University of Arizona Press, 2010.

Schlanger, Sarah H., ed. Traditions, Transitions, and Technologies: Proceedings of the 2000 Southwest Symposium. Boulder, Colo.: University Press of Colorado, 2002.

Schmid, Elisabeth. Atlas of Animal Bones for Prehistorians, Archaeologist, and Quaternary Geologists. Amsterdam: Elsevier Publishing Company, 1972.

Schmidt, Kari M. "Period Subsistence on the Pajarito Plateau: Faunal Remains from Five Room Block Sites.” Kiva. Vol. 72, No. 2 (Winter 2007), pp. 155-72.

Schneider, Harold K. Economic Man: The Anthropology of Economics. Salem, Wisc.: Sheffield Publishing Company, 1974.

Schorger, A.W. The Wild Turkey: Its History and Domestication. Norman, Okla.: University of Oklahoma Press, 1966.

Schroeder, Albert H. “A Brief History of the Southern Utes.” Southwestern Lore. Vol. 30 (1965), pp. 53-78.

Sebastian, Lynne. The Chaco Anasazi: Sociopolitical Evolution in the Prehistoric Southwest. Cambridge: Cambridge University Press, 1992.

Simmons, Alan H. "Excavations at Prehistoric Sites on the Navajo Indian Irrigation Project, Northwestern New Mexico." Journal of Field Archaeology. Vol. 10, No. 2 (Summer 1983), pp. 155-76.

----------. "New Evidence for the Early Use of Cultigens in the American Southwest." American Antiquity. Vol. 51, No. 1 (Jan. 1986), pp. 73-89.

Skinner, S. Alan. "A Survey of Field Houses at Sapawe, North Central New Mexico." Southwestern Lore. Vol. 31 (1965), pp. 18-24.

Smith, Bruce D. Middle Mississippi Exploitation of Animal Populations. Ann Arbor, Mich.: University of Michigan Press, 1975.

-------------. "The Role of Chenopodium as a Domesticate in Pre-maize Garden Systems of the Eastern United States.” Southeastern Archaeology. Vol. 4, No. 1 (Summer 1985), pp. 51-72.

4937 (Dec. 22, 1989), pp. 1566-71.

------------. The Emergence of Agriculture. New York: Scientific American Library, 1995.

------------. "The Initial Domestication of Cucurbita pepo in the Americas 10,000 Years

Ago.” Science. Vol. 276, No. 5314 (May 9, 1997), pp. 932-34.

. "Niche Construction and the Behavioral Context of Plant and Animal

Domestication.” Evolutionary Anthropology. Vol. 16 (2007), pp. 188-99.

--. "Resource Resilience, Human Niche Construction, and the Long-term

Sustainability of Pre-Columbian Subsistence Economies on the Mississippi River

Valley Corridor." Journal of Ethnobiology. Vol. 29, No. 2 (2009), pp. 167-83. 
ed. The Subsistence Economies of Indigenous North American Societies: A Handbook. Washington, D.C.: Smithsonian Institution Scholarly Press, 2011.

Smith, C. Wayne, et al, eds. Corn: Origin, History, Technology, and Production. Hoboken, N.J.: John Wiley \& Sons, Inc., 2004.

Smith, Harold T.U. "Tertiary Geology of the Abiquiu Quadrangle, New Mexico." The Journal of Geology. Vol. 46, No. 7 (Oct.-Nov., 1938), pp. 933-65.

Sobolik, Kristin D. Archaeobiology. Archaeologist's Toolkit, Volume 5. Walnut Creek, Calif.: AltaMira Press, 2003.

Staller, John E., et al, eds. Histories of Maize: Multidisciplinary Approaches to the Prehistory, Linguistics, Biogeography, Domestication, and Evolution of Maize. Walnut Creek, Calif.: Left Coast Press, 2009.

--------------, et al, eds. Histories of Maize in Mesoamerica: Multidisciplinary Approaches. Walnut Creek, Calif.: Left Coast Press, 2010.

Stein, Julie K. \& Linse, Angela R. Effects of Scale on Archaeological and Geoscientific Perspectives. Special Paper 283. Boulder, Colo.: Geological Society of North America, 1993.

Steward, Julian H. Basin-Plateau Aboriginal Sociopolitical Groups. Bureau of American Ethnology, Bulletin 120. Salt Lake City: University of Utah Press, 1997 (rpt. 1938 ed.).

Stiner, Mary C., et al. "Differential Burning, Recrystallization, and Fragmentation of Archaeological Bone.” Journal of Archaeological Science. Vol. 22 (1995), pp. 22337.

--------------, et al. "Bone Preservation in Hayonim Cave (Israel): a Macroscopic and Mineralogical Study.” Journal of Archaeological Science. Vol. 28 (2001), pp. 643-59.

Stuart, David E. \& Gauthier, Rory P. Prehistoric New Mexico: Background for Survey. Albuquerque: University of New Mexico Press, 1988 (rpt. 1984 ed.).

-------------. Anasazi America: Seventeen Centuries on the Road from Center Place. Albuquerque: University of New Mexico Press, 2000.

. The Ancient Southwest: Chaco Canyon, Bandelier, and Mesa Verde. Albuquerque: University of New Mexico Press, 2009.

Sullivan III, Alan P. \& Bayman, J. M., eds. Hinterlands and Regional Dynamics in the Ancient Southwest. Tucson, Ariz.: University of Arizona Press, 2007.

Tattersall, Ian. "The Abuse of Adaptation." Evolutionary Anthropology. Vol. 7, No. 4 (1999), pp. 115-6.

Thanukos, Anastasia. "How the Adaptation Got Its Start." Evolutionary Educational Outreach. Vol. 2 (published online Oct. 15, 2009), pp. 612-6.

Thayer, Samuel. The Forager's Harvest: A Guide to Identifying, Harvesting, and Preparing Edible Wild Plants. Ogema, Wis.: Forager's Harvest, 2006. 
Thomas, David H. "On Distinguishing Natural from Cultural Bone in Archaeological Sites." American Antiquity. Vol. 36, No. 3 (Jul. 1971), pp. 366-71.

Thompson, Victor D. \& Waggoner, James C., Jr., eds. The Archaeology and Historical Ecology of Small Scale Economies. Gainesville, Fla.: University Press of Florida, 2013.

Toll, H. Wolcott, ed. Soil, Water, Biology, and Belief in Prehistoric and Traditional Southwestern Agriculture. Special Publication No. 2. Albuquerque: New Mexico Archaeological Council, 1995.

Trigger, Bruce G. A History of Archaeological Thought. Cambridge: Cambridge University Press, 1989.

Upham, Steadman. “Adaptive Diversity and Southwestern Abandonment.” Journal of Anthropological Research. Vol. 40, No. 2 (1984), pp. 235-56.

Van Dyke, Ruth M. The Chaco Experience: Landscape and Ideology at the Center Place. Santa Fe: School for Advanced Research Press, 2007.

VanPool, Todd L. \& Leonard, Robert D. Quantitative Analysis in Archaeology. Malden, Mass.: Wiley-Blackwell, 2011.

Van Devender, Thomas R. \& Spaulding, W. Geoffrey. "Development of Vegetation and Climate in the Southwestern United States." Science. New Series, Vol. 204, No. 4393 (May 18, 1979), pp. 701-10.

Van Riper, Charles III \& Cole, Kenneth L., eds. The Colorado Plateau: Cultural, Biological, $\&$ Physical Research. Tucson, Ariz.: University of Arizona Press, 2004.

Vansina, Jan. Oral Tradition as History. Madison, Wisc.: University of Wisconsin Press, 1985.

Vargas, Victoria. D. Copper Bell Trade Patterns in the Prehispanic U.S. Southwest and Northwest Mexico. Arizona State Museum Archaeological Series 187. Tucson: Arizona State Museum/University of Arizona, 1995.

Varien, Mark D. \& Wilshusen, Richard H., eds. Seeking the Center Place: Archaeology and Ancient Communities in the Mesa Verde Region. Salt Lake City: University of Utah Press, 2002.

, et al. "Historical Ecology in the Mesa Verde Region: Results from the Village Ecodynamics Project.” American Antiquity. Vol. 72, No. 2 (Apr. 2007), pp. 273-99.

Vierra, Bradley J., ed. Current Research on the Late Prehistory and Early History of New Mexico. Special Publication 1. Albuquerque: New Mexico Archaeological Council, Jul. 1992.

, ed. Archaic Hunter-gatherer Archaeology in the American Southwest. Eastern New Mexico University Contributions in Anthropology, Vol. 13, No. 1. Portales, N. Mex.: Eastern New Mexico University, 1994. ed. Special Issue: The Northern Rio Grande. Kiva 73(2), 2007. 
, ed. From Mountain Top to Valley Bottom: Understanding Past Land Use in the Northern Rio Grande Valley, New Mexico. Salt Lake City: University of Utah Press, 2013.

Vivian, R. Gwinn. The Chacoan Prehistory of the San Juan Basin. New World Archaeological Record Series. San Diego: Academic Press, Inc., 1990.

----------. “Chaco Roads: Morphology.” Kiva. Vol. 63, No. 1 (2001), pp. 7-34. - “Chaco Roads: Function.” Kiva. Vol. 63, No. 1 (2001), pp. 35-67.

Warburton, Miranda \& Begay, Richard M. "An Exploration of Navajo-Anasazi Relationships.” Ethnohistory. Vol. 52, No. 3 (Summer 2005), pp. 533-61.

Warren, A. Helene. "The Ancient Mineral Industries of Cerro Pedernal, Rio Arriba County, New Mexico." In New Mexico Geological Society Guidebook, $25^{\text {th }}$ Field Conference, Ghost Ranch (Central-Northern N. Mex.), 1974, pp. 87-93.

Watson, J.P.N. "Fragmentation Analysis of Animal Bone Samples from Archaeological Sites." Archaeometry. Vol. 14, No. 2 (1972), pp. 221-7.

Weatherwax, Paul. The Story of the Maize Plant. Chicago: University of Chicago Press, 1923.

Web site: http://www.climate-charts.com. Climate-charts.com. Nov. 28, 2010.

Web site: http://geoinfo.nmt.edu. New Mexico Bureau of Geology \& Mineral Resources. Nov. 28, 2010.

Web site: http://www.ghostranch.org. Ghost Ranch, Feb. 22, 2015.

Web site: http://plato.stanford.edu/entries/vienna-circle/\#VerCriMetClaPer. Stanford Encyclopedia of Philosophy. Feb. 15, 2015.

Webster, Laurie D. \& McBrinn, Maxine E., eds. Archaeology without Borders: Contact, Commerce, and Change in the U.S. Southwest and Northwestern Mexico. Boulder, Colo.: University Press of Colorado, 2008.

Weisiger, Marsha. "The Origins of Navajo Pastoralism." Journal of the Southwest. Vol. 46, No. 2 (Summer 2004), pp. 253-82.

Wendorf, Fred, ed. Salvage Archaeology in the Chama Valley, New Mexico. Monographs of the School of American Research, No. 17. Santa Fe: School of American Research, Jun. 1, 1953.

\& Reed, Erik K. "An Alternative Reconstruction of Northern Rio Grande Prehistory.” El Palacio, Vol. 62, Nos. 5-6 (May-Jun. 1955), pp. 131-73.

Whalen, Michael E. "Moving Out of the Archaic on the Edge of the Southwest." American Antiquity. Vol. 59, No. 4 (Oct. 1994), pp. 622-38.

Wheeler, Alwyne \& Jones, Andrew K. G.: Fishes. Cambridge Manuals in Archaeology. Cambridge: Cambridge University Press, 1989.

White, Leslie A. The Science of Culture: A Study of Man and Civilization. New York: Grove Press, Inc.: 1949. 
White, Randall. Prehistoric Art: The Symbolic Journey of Humankind. New York: Harry N. Abrams, Inc., 2003.

White, Theodore E. "A Method of Calculating the Dietary Percentage of Various Food Animals Utilized by Aboriginal Peoples.” American Antiquity. Vol. 18, No. 4 (Apr. 1953), pp. 396-98.

Whitley, D.S. The Art of the Shaman: Rock Art of California. Salt Lake City: University of Utah Press, 2000.

Whitney, Ellie \& Rolfes, Sharon Rady. Understanding Nutrition (10 ${ }^{\text {th }}$ ed.). Belmont, Calif.: Thomson Wadsworth, 2005.

Whitten, Penelope \& Powers, Margaret A. A Preliminary Overview of Cultural History in the Lower Rio Chama, New Mexico. Contributions to Anthropology Series, No. 300. San Juan County Archaeological Research Center and Library, Sep. 15, 1980.

Wilcox, David R. \& Masse, Bruce W., eds. The Protohistoric Period in the North American Southwest, AD 1450-1700. Anthropological Research Papers No. 24. Tempe, Ariz.: Arizona State University, 1981.

Willey, Gordon R. \& Sabloff, Jeremy A. A History of American Archaeology ( ${ }^{\text {rd }}$ ed.). New York: W.H. Freeman \& Company, 1993.

Williams, David B. A Naturalist's Guide to Canyon Country. Guilford, Conn.: Morris Book Publishing, LLC, 2000.

Williams, Lovett E., Jr. The Art and Science of Wild Turkey Hunting. Gainesville, Fla.: Real Turkeys Publishers, 1989.

Wills, W. H. Early Prehistoric Agriculture in the American Southwest. Santa Fe: School of American Research Press, 1988.

\& Leonard, Robert D., eds. The Ancient Southwestern Community: Models and Methods for the Study of Prehistoric Social Organization. Albuquerque: University of New Mexico Press, 1994.

Wilshusen, Richard H., et al, eds. Crucible of the Pueblos: The Early Pueblo Period in the Northern Southwest. Monograph 71. Los Angeles: Cotsen Institute of Archaeology Press, UCLA, 2012.

Wilson, Hugh D. "Artificial Hybridization among Species of Chenopodium sect. Chenopodium." Systematic Botany. Vol. 5, No. 3 (Jul.-Sep., 1980), pp. 253-63.

Wiseman, Regge N. \& Ware, John A. The Gavilan Project: Testing Results and a Data Recovery Plan for Eleven Prehistoric and Historic Sites Along U.S. 285 Near Ojo Caliente, Rio Arriba County, New Mexico. Archaeology Notes 194. Santa Fe: Museum of New Mexico Office of Archaeological Studies, 1996.

Woodhouse, S.W. Ed. Andrew Wallace \& Richard H. Hevly. From Texas to San Diego in 1851: The Overland Journey of Dr. S. W. Woodhouse, Surgeon-naturalist of the Sitgreaves Expedition. Lubbock, Tex.: Texas Tech University Press, 2007 (rpt. 1851 ed.). 
Young, L.C. "Lithics and Adaptive Diversity: An Examination of Limited-Activity Sites in Northeast Arizona." Journal of Anthropological Research, Vol. 50, No. 2 (1994), pp. $141-54$. 


\section{CURRICULUM VITAE}

Name:

Address:

DOB:

Education:

Awards:

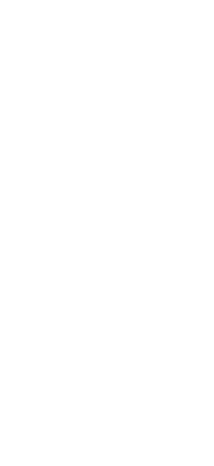


1993 Greg Grummer Prize in Poetry, Phoebe: A Journal of Literary Arts (George Mason University)

Professional Societies: Society for American Archaeology

National Meeting

Presentation:

SAA poster presentation 2012 (Memphis, Tennessee)

Symposium:

Participant, Liberty Fund Conference on David Graeber's

Debt: The First 5,000 Years (Nov. 7-9, 2014)

Other:

4.0 combined GPA, UofL graduate \& undergraduate classes

Part-time lecturer Fall 2012-present:

- ANTH 203: Introduction to World Prehistory (online)

- ANTH 204: Introduction to Archaeology (classroom)

- Chose textbooks, developed course content, delivered or recorded lectures, wrote and graded exams

Seven times guest lecturer, ANTH 304: Prehistoric Europe

Served as Graduate Teaching Fellow and lead student representative on UofL Anthropology Department's Ideas 2 Action (i2a) critical-thinking initiative during Spring 2013. Authored i2a committee final report and faculty presentation Graduate Assistant, UofL Anthropology Department, Fall 2011-Spring 2012

Participation as field technician for seven seasons in Ghost Ranch Archaeological Seminar (2006-2012) Publisher \& editor, Ghost Ranch Archaeological Bulletin 